\title{
FEDERAL AGENCIES ACTIVE IN CHEMICAL INDUSTRY-RELATED RESEARCH AND DEVELOPMENT
}

September 29, 1995

Prepared for:

U.S. Departmeat of Energy

Office of Energy Efficiency and Renewable Energy

Office of Industrial Technologies

Washington, DC 20585

Under Contract No. DE-AC01-91CE40956

Prepared by:

Research Management Consultants, Inc.

Washington, DC

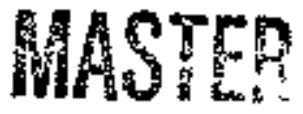




\section{DISCLAIMER}

This report wis prepared as an ecoodot or work spossoced by an sogeng of the bitited

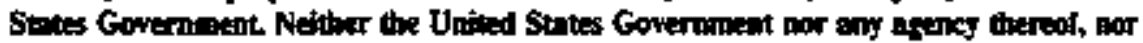

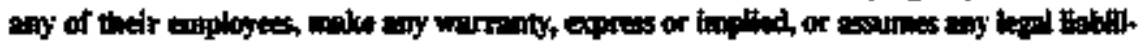

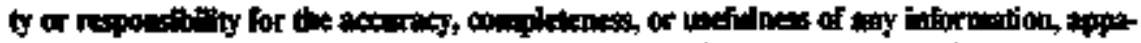

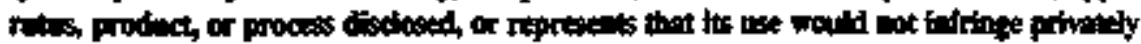

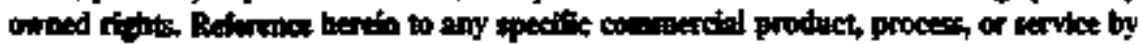

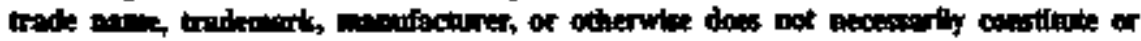

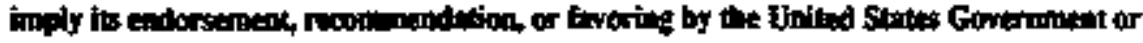

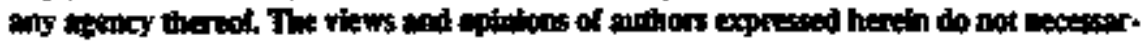

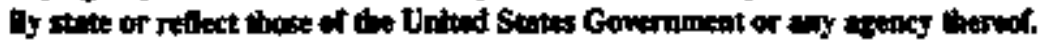




\section{DISCLAIMER}

Portions of this document may be itlegible electronic image products. Images are produced from the best avaliable original document. 


\section{EXECUTIVE SUMMARY}

The Energy Policy Act of 1992 calis for a program to further the commercialization of renewable energy and energy efficient technologies for, the industrial sector. In response to this, the Department of Energy (DOE) has realigned its Office of Industrial Techsologies (OIT) around seven energy-intensive industries, one of the seven being the chemical industry.

The primary objective of the OIT Chemical Industry "Tean" is to work in partnership with the U.S. chemical industry to maximize economic, energy, and envirommental benefits through research and developruent of imnovative technologies.

One of the goals of the chemical industry team is to develop the appropriate interfaces within DOE and extemal federal, state, and private sector stakeholders, along with communication of efforts and successes to customers and stakeholders. This document was developed to inventory organizations within the federal goverument on current chemical industry-related research and development.

While an amount of funding or number of projects specifically relating to chemical industry research and developtrient was not defined in all organizations, identified were about 60 distinct organizations representing 7 cabinet-level departments and 4 independent agencies, with research efforts exceeding \$3.5 billion in fiscal year (FY) 1995. Efforts were found to range from less than $\$ 500$ thousand per year at the Departments of Agriculture and the Interior to over $\$ 100$ million per year at the Departments of Commerce, Defense, Energy, and Health and Hurnan Services and the National Aeronantics and Space Administration. The total number of projects in these programs exceded 10,000.

This document is complete to the extent that agencies voluntered information. Additions, corrections, and changes are encouraged and will be incorporated in futtre revisions. 



\section{TABLE OF CONTENTS}

EXECUTIVE SUMMARY $\ldots \ldots \ldots \ldots \ldots \ldots \ldots \ldots \ldots \ldots \ldots \ldots \ldots \ldots$

TABEE OF CONTENTS $\ldots \ldots \ldots \ldots \ldots \ldots \ldots \ldots \ldots \ldots \ldots \ldots \ldots \ldots$

INTRODUCTION $\ldots \ldots \ldots \ldots \ldots \ldots \ldots \ldots \ldots \ldots \ldots \ldots \ldots \ldots \ldots \ldots \ldots \ldots \ldots \ldots$

FEDERAL AGENCIES

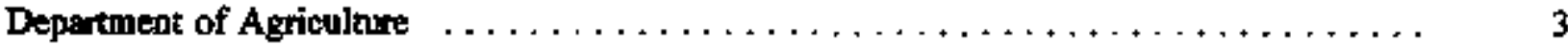

Agriculmral Research Service $\ldots \ldots \ldots \ldots \ldots \ldots \ldots \ldots \ldots \ldots \ldots \ldots \ldots \ldots$

Cooperative State Research Service $\ldots \ldots \ldots \ldots \ldots \ldots \ldots \ldots \ldots \ldots \ldots \ldots$ s

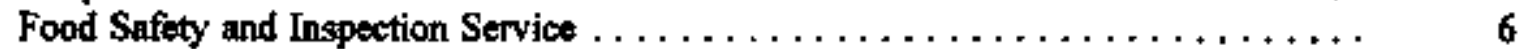

Forest Strvice $\ldots \ldots \ldots \ldots \ldots \ldots \ldots \ldots \ldots \ldots \ldots \ldots \ldots \ldots$

Department of Commence $\ldots \ldots \ldots \ldots \ldots \ldots \ldots \ldots \ldots \ldots \ldots \ldots \ldots \ldots \ldots \ldots \ldots, \ldots \ldots$

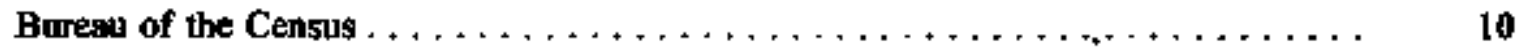

National Institute of Stardands and Fechnology

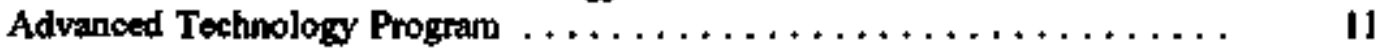

Chemical Science and Technology Laboratory ............... I3

Materials Science and Engineering Laboratory . . . . . . . . . . . . 15

Department of Defense $\ldots \ldots \ldots \ldots \ldots \ldots \ldots \ldots \ldots \ldots \ldots \ldots \ldots \ldots$

Advanced Research Projects Agency

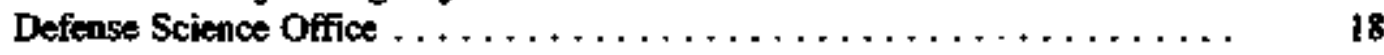

Technology Reinvestment Project $\ldots \ldots \ldots \ldots \ldots \ldots \ldots \ldots \ldots \ldots$

Deppertment of the Air Force

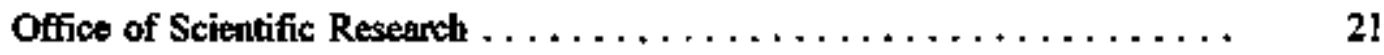

Small Business Innovation Research Program $\ldots \ldots \ldots \ldots \ldots \ldots \ldots \ldots$

Department of the Army

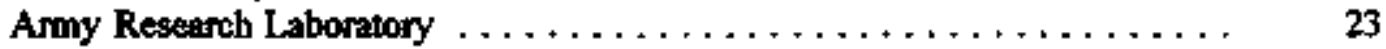

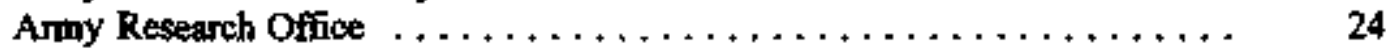

Department of the Navy

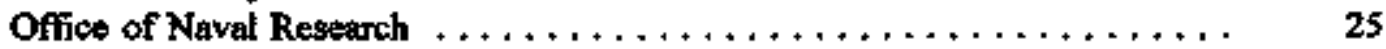

Small Business Innovation Research Program $\ldots \ldots \ldots \ldots \ldots \ldots \ldots \ldots \ldots \ldots$

Strategic Environmental Research and Development Program . . . . . . . . . 28

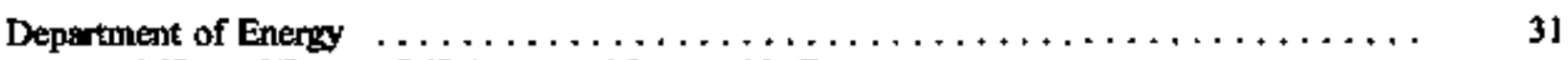

Office of Energy Efficiency and Renewable Energy
Office of Industrial Technologies $\ldots \ldots \ldots \ldots \ldots \ldots \ldots \ldots \ldots \ldots \ldots$

Office of Building Technologies $\ldots \ldots \ldots \ldots \ldots \ldots \ldots \ldots \ldots \ldots \ldots$

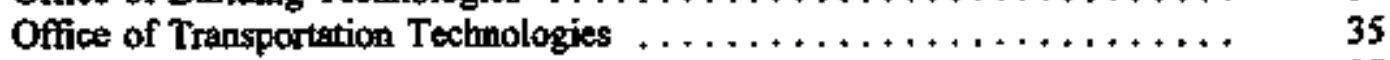

Office of Utility Technologies $\ldots \ldots \ldots \ldots \ldots \ldots \ldots \ldots \ldots \ldots \ldots \ldots$

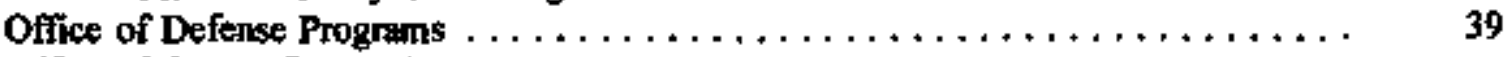

Office of Enitigy Research 


\section{Basic Energy Sciences}

Advanced Energy Projects Division $\ldots \ldots \ldots \ldots \ldots \ldots \ldots \ldots$

Chemical Sciences Division . . . . . . . . . . . . . . .

Energy Biosciences Division $\ldots \ldots \ldots \ldots \ldots \ldots \ldots \ldots \ldots$

Small Business Innovation Research (SBIR) Office $\ldots \ldots \ldots \ldots \ldots$

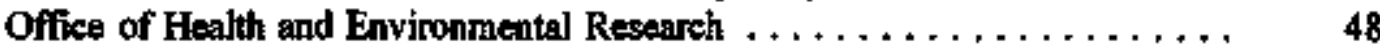

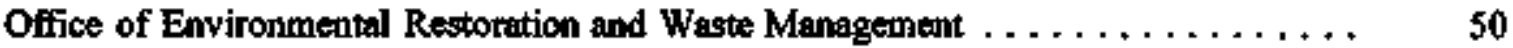

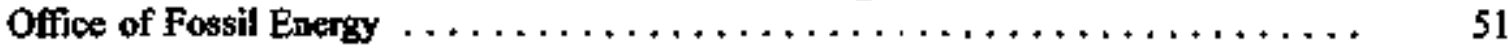

DOE Laboratories and Facilities $\ldots \ldots \ldots \ldots \ldots \ldots \ldots \ldots \ldots \ldots \ldots \ldots \ldots \ldots \ldots$

Department of Heahth and Human Services $\ldots \ldots \ldots \ldots \ldots \ldots \ldots \ldots \ldots \ldots \ldots$

Public Health Service

Agency for Toxic Substances and Disease Registry $\ldots \ldots \ldots \ldots \ldots \ldots \ldots \ldots$

Centers for Disease Control

National Center for Environmental Health . . . . . . . . . . . . .

National Institute for Occupational Safety and Health

Food and Drug Administration

Center for Dang Evaluation and Research . . . . . . . . . .

National Center for Toxicological Research $\ldots \ldots \ldots \ldots \ldots \ldots \ldots$

National Institures of Health

National Institute of Environmental Health Sciences

National Toxicology Program $\ldots \ldots \ldots \ldots \ldots \ldots \ldots \ldots$

Superfund Basic Research Program ... . . . . . . .

National Instritute of General Medical Sciences . . . . . . . . .

Department of the Imterior $\ldots \ldots \ldots \ldots \ldots \ldots \ldots \ldots \ldots \ldots \ldots \ldots \ldots \ldots \ldots \ldots$

Bureau of Mines

Center for Materials Research Partnerships $\ldots \ldots \ldots \ldots \ldots \ldots \ldots \ldots$

Center for Pollution Prevention and Control $\ldots \ldots \ldots \ldots \ldots \ldots \ldots \ldots \ldots$

Division of Environmental Technology $\ldots \ldots \ldots \ldots \ldots \ldots \ldots \ldots \ldots \ldots$

Department of Transportation $\ldots \ldots \ldots \ldots \ldots \ldots \ldots \ldots \ldots \ldots \ldots \ldots \ldots$

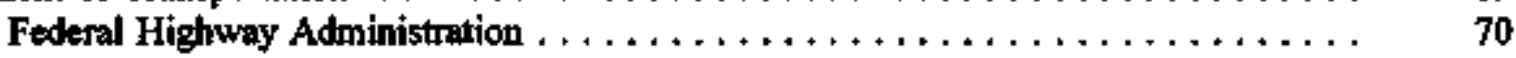

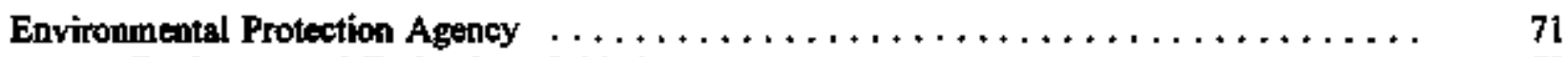

Environmental Technology Initiative $\ldots \ldots \ldots \ldots \ldots \ldots \ldots \ldots \ldots \ldots \ldots \ldots \ldots \ldots, 72$

Office of Prevention, Pesticides and Toxic Substances

Design for the Environment Program $\ldots \ldots \ldots \ldots \ldots \ldots \ldots \ldots \ldots \ldots \ldots$ 74

Office of Pollution Prevention $\ldots \ldots \ldots \ldots \ldots \ldots \ldots \ldots \ldots \ldots \ldots \ldots$

Office of Research and Development

National Center for Extramural Research and Quality Assurance . . . . . . . 76

National Risk Management Research Laboratory

Air Pollution Prevention and Control Division $\ldots \ldots \ldots \ldots \ldots \ldots$

Pollution Prevention Research Branch . . . . . . . . . . . . 
National Aeronautics and space Administration $\ldots \ldots \ldots \ldots \ldots \ldots \ldots \ldots \ldots \ldots$

Microgravity Sciences and Applikations Division $\ldots \ldots \ldots \ldots \ldots \ldots \ldots \ldots \ldots$

Office of Space Access and Technology $\ldots \ldots \ldots \ldots \ldots \ldots \ldots \ldots \ldots \ldots$

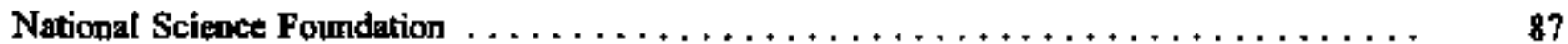

Bioengineering and Environmental Systems Division $\ldots \ldots \ldots \ldots \ldots \ldots \ldots \ldots \ldots$ $\quad \mathbf{8 8}$

Chetnical and Transport Systems Division $\ldots \ldots \ldots \ldots \ldots \ldots \ldots \ldots \ldots \ldots$

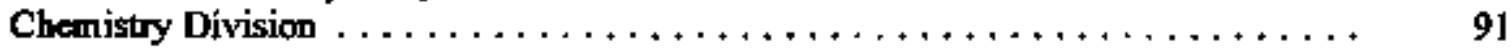

Design, Manufacture, and Industrial Innovation Division $\ldots \ldots \ldots \ldots \ldots \ldots \ldots$ 92

Materials Research Division $\ldots \ldots \ldots \ldots \ldots \ldots \ldots \ldots \ldots \ldots \ldots \ldots \ldots \ldots \ldots$

Molecular and Cellular Biosciences Divistion $\ldots \ldots \ldots \ldots \ldots \ldots \ldots \ldots \ldots \ldots \ldots \quad 94$

Tennessee Valley Authority $\ldots \ldots \ldots \ldots \ldots \ldots \ldots \ldots \ldots \ldots \ldots \ldots \ldots \ldots \ldots$

Environmentad Research Center $\ldots \ldots \ldots \ldots \ldots \ldots \ldots \ldots \ldots \ldots \ldots \ldots \ldots$

AVALAALE INTERNET HOME PAGES FOR ADDITIONAL INFORMATION $\ldots \ldots . \quad 99$

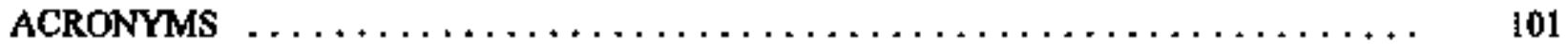

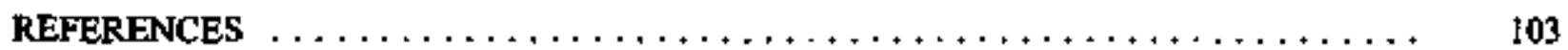

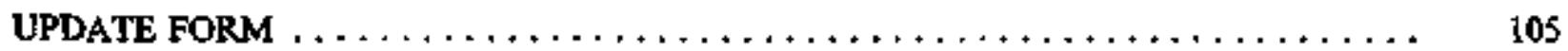

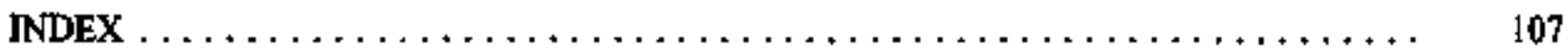




\section{INTRODUCTION}

The U.S. chemical industry is an exceptionally large, complex, and diverse segment of the manufacturing sector. In 1992, this industry shipped products worth $\$ 306$ billion while employing 850,000 workers. The industry produces more than 60,000 products ranging from basic organic and inorganic commodity chemicals such as ethylene and sulfuric acid to mass-market consumer goods such as drugs, detergents and paints.

A key to the success of the chentical industry has been its traditionally large $R \& D$ funding and its strong propensity to innovate, In 1992, more than $\$ 16$ billion was spent on R\&D, or roughly $5.5 \%$ of chemical industry shipments. This compares to a minufacturing sector averige of $3 \%$.

In addition, the chemical industry is a large energy user. In 1991, the industry used over 5 quadrillion Bul of energy, or about $25 \%$ of manufacturing energy use. The chemical industry also generates large amounts of waste, including about $20 \%$ of non-hazardous manufacturing wastes, about $90 \%$ of hazardous manufacturing wastes, and about $40 \%$ of toxic manufacturing wastes.

Chemical Industry Profile (data for latest year available)

\begin{tabular}{|c|c|}
\hline Value of Slujiments & 5306 billion \\
\hline Tosal Ermploymort & 850,000 jobs \\
\hline Capital Expenditures & S16.5 billion \\
\hline Nat Ttode Balarix & $\$ 15.5$ billion \\
\hline Energy Consumpition & 5.05 quadriltion Etu \\
\hline Waste Gencration & 1.84 billion tons \\
\hline Average Hourly Eariding & 515.25 \\
\hline
\end{tabular}

The Department of Energy (DOE) recognizes the opportunity to save energy, retuce pollution, and improve the competitiveness of the U.S. chemical industry through the development of inavovative technologies. As part of DOE's Office of Energy Efficiency and Renewable Energy, the Office of Industrial Technologies (OIT), through partnerships with indnstry, government, and non-governmental organizations, develops and delivers advanced energy efficiency, renewable energy, and pollution prevention technologies for industrial applications.

For the chemical industry in particular, technologies that incnease chemical conversion efficiency, reduce fossil fuel dependence, reduce waste product generation, increase conversion and recycling of waste products, and better utilize waste heat are being developed by OIT.

The development of these technologies have been authorized by several legislative ections, most recently by the passage of the Energy Policy Act of 1992 (Public Law 102-486), and in particular, Sections 210] (Gentral Improved Energy Efficiency). Section 2107 (Improving Efficiency in Energy-Intensive Industries), and Section 2108 (Energy Efficient Environmental Program).

OTT has recently been realigned into teams to focus primarily on seven energy-intensive industries, one of the seven being the chentical industry. The management and mderstanding of the OIT Chemical lndustry Team efforts can be assisted by the development of a comprehensive inventory of federal agency involvement in these areas. The intent of the inventory is to reduce rechundant efforts and identify areas of mutual intexest, in order to increase the effectiveness of the management of these programs. 
This report includes R\&D efforts that relate to the following:

- Chemical industry R\&D (both product and process)

- Chemicals usser's R\&D (i,e, toxic materials substitution)

- Chemicals equipment supplier R\&D (i.e., automated machinery)

- Chemicals feedstock supplier R\&D (i.e., alternative feedstocks)

- Chemical transportation R\&D (i.e., from manufacturing site to end-user).

\section{Report Format}

As part of the OIT Chemical Industry Team communications efforts, this report includes summaries of federal agency involvement in chemical industry-related R\&D. In particular, each summary provides available information including:

- The agency, agency branch, maiting address, point-of-contact, position, telephont number, fax number, and e-mail address.

- A synopsis of the agency and its efforts in chenical industry-related R\&D.

- The amount of funding allocated for these efforts, if a specific amount can be determined; or an overall amount of funding for the program or organization.

- The kength of involvement or commitment to chemical industry-related RaD efforts.

- Any relationships to the Office of Industrial Technologies (if applicabie).

- A date of last revision for the summary.

\section{Inventory Participants}

Federal agencies included in this report include the following:

- Department of Agriculture

- Department of Cornmerce

- Department of Defense

- Department of Energy

- Department of Health and Human Services

- Department of the Interior

- Department of Transportation

- Environmental Protection Agency

- National Aeronautics and Space Administration

- National Science Foundation

- Tennessee Valley Authotity 


\section{DEPARTMENT \\ OF AGRICULTURE}

The Department of Agrientture benefits all Americans daily. It works to improve and maintain farm income and to develop and expand makkes abroad for agricultural products. The Department helps to curb and to cure poverty, hunger, and malnutrition. It works to enhance the environment and to maintain our production capacity by helping landowners protect the soil, water, forests, and other natural resources. Rural development, eredit, and conservation programs are key resources for carrying out national growth policies. Department research findings directly or indirectly benefit all Americans. The Department, throvgh inspection and grading services, safeguards and ensures standards of quality ia the dajly food supply. 
U.S. Department of Agriculture

Agricultural Research Service

Building 005

Bettsville, MD 20705

Contact: Dr. Wilda Martinez

Phone: $\quad 301-504-6275$

Fax: $\quad 301-504-6699$

E-nail: $\quad$ Unkmown

Description of agency inwohement in chamical industry-reloted R\&D;

The Agriculturad Research Service administers fundamental and applied research to solve problems in animal and plant protection and production; the conservation and improvement of soil, water, and air, the processing, storage, and distribution of farm proxtucts; and human nutrition. The research applies to a wide range of goals, commodities, natural resources, fields of science, and geographic, climatic, and environmental conditions. Research activities are carried out at over 100 domestic locations. Much of this researeh is conducted in cooperation with state partners in the universitie and experimental stations, other federal agencies, and private organizations.

Amount of funding avaluble for chemical industry-reloted RdD;

Total funding available for chemistry research efforts was approxinateily $\$ 59$ million in both FY 94 and FY 95.

Length of involvement in chemical industry-related R\&D efforts: Unknown.

Relationship to OTT programs (If applicable); None.

Notes:

Sources of infonnation: U.S. Government Momual of Federal Agencies.

Personal communication.

Date of last revision: September 29, 1995. 
U.S. Department of Agriculture

Cooperative State Reseanch, Education and Extension Service

Office of Agricultural Materials

342 Aerospace Center

Washington, DC 20250

Contact: Dr. Danied E. Kugler

Phone: $\quad 202.401-6861$

Fax: $\quad 202-40]-5179$

E-mail: Unknown

\section{Descrlption of agency involvement in chemical indastry-related R\&D:}

The Cocperative State Reserarch, Education and Extension Service facilitetes the advancennent of science and technology in the nationwide agricultural tesearch system by providing federal resources, participating in cooperative program planning and evaluation, and developing a forum for coordination between the State Agricultural Experiment Stations, the Department of Agriculture, foderal reserch scientists, and industry partness. The primary function of the Service is the administration of federal appropriations for agricultural research and development carried on by the State Agricultural Experiment Stations and by approved schools. Service programs include research on specific problems in agricuture. The Service conducts research and development to promote new jndustrial uses and markets for U.S. erops. Crops under research for new tuses or markets include: castor, lesquerella, corn, crambe, rapeseed, dairy products, forest byproducts, guayule, jojoba, livestock byproducts, milkweed, soybeans, taxol, and wheat. Some cument or potential uses of these crops include: ethanol, plastics, nylon, soaps and detergents, paints, pharmaceuticals, nattrial rubber, biodegradable polymers, and acthesives.

Amownt of fonding avallable for chentcal industry-related R\&D:

Funding for Cooperative State Research, Education and Extension Service non-food research and development in FY 94 was approximately $\$ 16.0$ million, and funding in FY 95 was approximateiy $\$ \$ 5.6$ million.

Length of involvement in chemical indistry-related RAD efforts:

The Cooperative State Research, Education and Extension Service has been involved in retated efforts since the Native Latex Act was passed by Congress in 1978.

Relationship to OTT prograns (ff applicable):

The Service has partmered with OIT in Biobased Expos in 1992 and 1994; and the Service also interfaces on agricultural matters with OIT programs (i.e., Alternative Feedstocks program).

Notes:

Sources of information: Personal commurication.

New Munarpial Uses, New Markets for US. Crops, U.S. Department of Agriculture.

U.S. Government Mantwal of Federal Agenctes.

Dafe of last revision: September 15, 1995. 
U.S. Department of Agrieulture

Food Safety and Inspection Service

14th and Independence Ave. SW

Room 2128 South Building

Washington, DC 20250

Contact $\quad$ Mr. Victor Randecker

Phone: 202-205-0428

Fax: 202-205-7392

E-mail: USDAFSIS/S=RANDECKER@MHS.ATTMAIL.COM

\section{Description of agency tavolvement in chemical industry-redated RAD:}

The Food Safety and Inspection Service (FSIS) is an agency of the U.S. Department of Agriculnure that administers a comprebensive system of inspection laws under the Federal Meat Inspection Act, the Poultry Products Inspection Act, and the Egg Pnoducts Inspection Act The laws protect consumers by ensuring that meat, poultry, and egg products are wholesome, unadulterated, and properly marked, labeled, and packaged. The laws also protect packers by ensuring that no one gains an unfair economic advantage by marketing unwtiolesome or misbranded products.

Only federally inspected meat and poultry plants may sell their products in interstate of foreign commerce. In 1994, FSIS inspected over 129 million head of livestock and over 7 billion birds. Moro than 8,100 FSIS ermployees, including more than 1,100 veterinarians, carry out the inspection laws in some 6,700 meat, poultry, egg, and other slaughtesing or processing plants. The meat, poultry, and egg product inspection program is responsible for inspecting, before and after skanghter, those birds, animals, and egg products intended for use as food for humans and maintaining surveillance of the further processing of meat, poultry, and egg products to assure the safety of the nation's food supply.

The FSIS Science and Technology Program provides analytical, methods development, and other support to all inspection activities. Antylytical service support in pathology, chemistry, microbiology, and entomology is provided by the three multidisciplinary laboratories located in Athens, Georgia; St. Louis, Missouri; and Alameda, Califomia. In addition, FSIS maintains a laboratory in Beltsville, Maryland that provides methods development support in mictobiology and serology.

Investigations for Reductions of Hazandous Waste in Laboratory Operations: FSIS is investigating novel approaches for the elimination, reduction, or recycling of hazardous waste generated in laboratory or field operations. Activities have specifically targeted the following chemicals whose volume or toxicity are of greatest concern: mencury, silver, petroleum ether, ethanol, and xylene. Efforts have also been directed towand reduction and reuse of organic solvents in FSIS laboratories and field operations. Most recently, FSIS has initiated a program to autornate analytical procedures while reducing the use or geveration of toxic or hazardous materials. This prograrn is designed to acquire new or modified technology (equipment or procedures) and evaluate its effectiveness and applicability in the operations of a regulatory laboratory.

Current projects inclode:

- Protein Deternination; A Leco 2000 Nitrogen Analyzer was purchased to investigate the application of combustion analysis to protein determination. The unit should replace the cunrent 
Kjeldahl technology, which generates both acidic and merenric sulfide waste.

- Fat Extraction: FSIS has purchased a Supercritical Fluid Extraction unit to investigate the replacement of the current use of solvents (petroleum ether) for fat extraction from meat and poultry samples.

- Salt Analyses: The current salt analysis generates a silver containing nitric acid waste liguid. A capillary electrophoresis instrument was acquired to potentially replace this method. Future studies will investigate the use of CE technology in other HPLC methodologies.

- Solvent Recycling: The FSIS laboratories have each acquired solvent distillation units to recover spent xylene and ethanol solvents from histopathology activities. Applications for use with other operations are being investigated.

Amount of funding avaltable for chemical industry-related RdD:

In FY 94, approximately \$150 thousand was obligated within FSIS. In FY 95, approximately \$200 thousand will be obligated.

Length of involvement in chentiod indastry-related RQD fforts:

FSIS bas been involved in the application of pollution prevention/source reduction principles in agency operations for over 10 years.

Retartonshlp to OTT prograns (ff eqpilcable): None.

Notes:

Sources of information: Personal communication.

Date of last revision: August 21, 1995. 
U.S. Department of Agrieniture

Forest Service, Fonest Products and Harvesting Research

P.O. Box 96090

Washington, DC 20090-6090

Contact: Dr. Howard Rosen

Phone: 202-205-1565

Fax: 202-205-2497

E-nail: $\quad$ FAWAS-H.ROSEN/U1-W01C@MHS.ATTMAIl.COM

Description of agency involvement in chemical industry-related ReD:

As a subset of the Forest Service mission to achieve quality land managernent under the sustainable multiple-use management concept to meet the diverse needs of people, Forest Products and Harvesting Research seeks to provide the scientific information and technology to harvest, produce, and use wood products in ways that are efficient, safe, and envircommentally beneficial.

The primary areas of chemical industry retated R\&D emphasize the pulping processes, reycling of wastepaper and waste wood to paper and high-valued composite products, athesives, bioprocessing, bioremediation, fire retardance for wood-based products, preservation, wood finishing, drying, renewable energy fuets, and recovery of wood-based chemicals. The Forest Service curently has 13 project groups (with over 30 projects) in these areas. Sample projects include:

- Adhesives from renewable resources (Pineville, LA)

- Bionemedistion of contaminated soils (Madison, WI)

- Biopulping (Madison, WT)

- Composite processing from recycled wood and plastic raw materials (Madison, WI)

- Fermentation of wood hydrolysates (Madison, WI)

- Penetration of wood-based preservatives (Carbondale, IL)

- VOC-compliant coatings for wood materials (Madison, WI)

Amount of funding apallable for chemical industry-related RaD:

In FY 94, around \$9.7 million was appropriated, and in FY 95, around \$10.1 million was appropriated.

Length of involvement in chemical industry-related R\&D gforts:

The Forest Service's forest products research efforts began at the turn of the century but was focused with the establishment of the Fortst Products Laboratory in Madison, Wisconsin in 1910. This taboratory, as well as many of the regional locations throughout the United States, has continued to build and expand areas of research related to the chemical industry.

Relotionship to OrT prograsis (ff applicable):

The Forest Service is currentfy working with OIT in approaches to non-chlorine bleaching to rednce contaminants in the effluents from patp mills.

Notes:

Sources of information: Personal communicntion.

Date of Last revision: August 16, 1995. 


\section{DEPARTMENT \\ OF \\ COMMERCE}

The Department of Commerce encomages, serves, and promotes the Nation's international trade, economic growth, and technological advancement. Within this framework and together with a policy of promoting the national interest tbrough the encouragement of the competitive fire enterprise system, the Department provides e wide variety of programs. It offers assistance and information to increase America's competitiveness in the wotld economy; administers programs to prevent unfair foreign trade competition; provides social and economic statistics and analyses for business and govemment planners; provides research and support for the increased use of scientific, engineering and technological development, works to improve our understanding and benefits of the Earth's physical environment and ocenic rescurces; grants patents and registers trademarks; develops policies and conducts research on telecommuntcations; provides assistance to promote domestic economic development; promotes travel to the United States by residents of foreign countries; and assists in the growth of minority businesses. 
U.S. Department of Commence

Bureau of the Census

Center for Economic Studies, EPCD

Room 1587, FB 3

Washimgton, DC 20233-6101

Contact: Ms. Mary L. Streitwieser

Phone: $\quad 301-457.1837$

Fax: $\quad 301-457-1235$

E-mail: $\quad$ MSTREITW@CENSUS.GOV

Description of ogency involvement in chemical industry-related RQD:

The Office of Industrial Technologies contracted with the Center for Eoononic Studies to develop a database and software to generate summary information regarding industrial waste emissions and energy usage for detailed SIC industries. A series of reports from the micro database were submitted to OIT, including one on the intensity and distribution of toxic emissions from the chemical industries (5-digit SIC level). Targets for waste rectuction were identified.

Amount of fanding avalable for chemical industry-related RQD:

In FY 94, \$205,000 was authorized for this work. No funding was authorizad in FY 95.

Length of invotwement in chemical industry-related RED efforts:

This project was initiated in 1991.

Relationship to OIT progranas (ff applictbie): None other than stated.

Notes:

Sources of information: Personal communication.

Darfe of las reviston: Angust 1, 1995. 

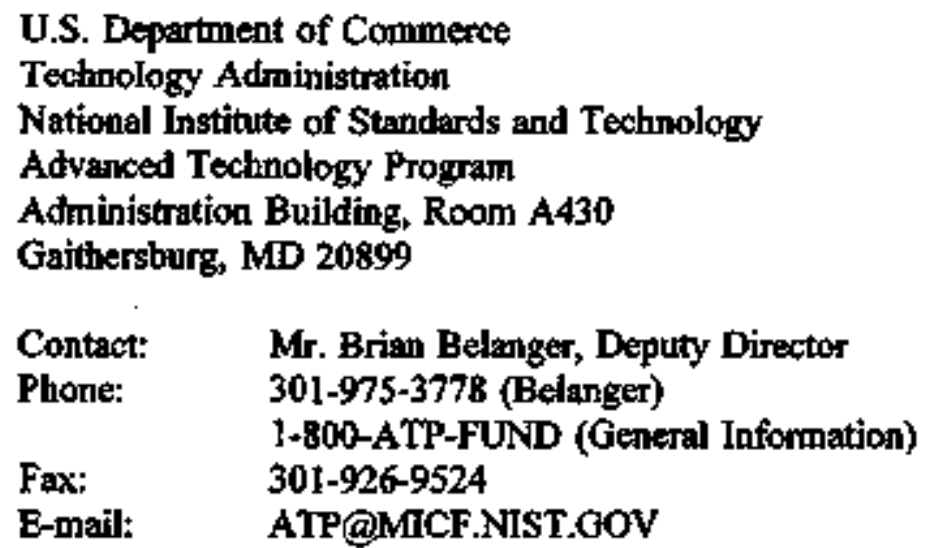

Description of agency buohement in chenical Industy-related ReD:

The National Institute of Standards and Technology (NIST) is directed specifically to assist industry in developing technology to improve product quality; to modemize manufacturing processes; to ensure product reliability; and to facilitate rapid commercialization of products based on new scientific discovery. As a nor-regulatory agency of the Department's Technology Administration, NIST aids U.S. industry through research and services; carries ont selected programs in public health and safty and environmental improvement; and supports the U.S. seientific and engineering research communities through fundarnental research.

The axvanced technology program is involved in providing grants to all areas of technology. Currently, there are few restrictions regerding the type of projects funded (e.g., military R\&D). In FY 95, 12 solicitations were issued, inchuding a general solicitation and a targeted solicitation for cotalysis and biocatalysis. A partial listing of chemical industry-related projects from prior years include:

- Development of Improved Functional Properties in Renewable-Resource-Based Biodegradable Plastics (Cargill, Inc)

- Developenent of Improved Catalysts using Nanometer-Scale Technology (Catalytica, Inc.; Microfluidics International Corp.)

- Duel Purpose Ceramic Membranes (BP Chemicals; Praxair, Inc; Seattle Speciajty Ceramics, Inc.; University Of Missotri - Rolla)

Awards from the catalysis and biocatalysis solicitation are as follows:

- Bjosynthesis of Monomers (General Elextric)

- Breakthrough Process for Direct Oxidation of Propylene to Propylene Oxide (Dow Chemical)

- Breakthrough Technology for Oxidation of Alkanes (Sun Company; Rohm and Hass)

- Computational Methods for Catalyst Design (Phillips Petroleum)

- Continuous Biocatalytic Systems for the Production of Chemicals from Renewable Resources (Genencor intermational, Eastman Chemical, Electrosynthesis Company, MicroGenomics, Argonne National Labxratory)

- Elastomeric Polypropylene and Elastic Non-wovens Venture (Amoco, Fiberweb North America)

- Polar-Tolerant Organometallic Catalytic Tochnology for Functionalized Linear Polyolefins (W.R. Grace)

- Tailored Optical Polymers Through a Novel Caralyst System (BF Goodrich, 3M)

- Thin-Film Solid Acid Catalyst for Refinery Alkylation (ABB Lummus Global) 
Awotrst of funding abaitoble for chemical indistry-related R\&D;

In FY 94, \$199.5 million was authorized for all categories (approximately \$85 million for the general solicitation and the remainder for tirgeted solicitations). In FY 95, an estimated \$25-30 million was allocated for the general solicitation and SIS was allocated for the catalysis and biocatalysis targeted solicitation. For individual companies, the program can find up to $\$ 2$ million in direct costs over a three year period. Joint venture projects may be funded for up to five years with no funding liwit, but have a minimum $50 \%$ cost-sharing requirement.

Length of involvement in chemical industry-reloted RdD efforts:

The Advanced Technology Program began in 1990.

Relationship to OIT programs (ff appltcable):

The Advanced Techsology Program maintains an informal relationship with several OrT programs.

Notes:

Sources of information: $\quad$ U.S. Govemment Momual of Federal Agencies. Advanced Technology Program Propasal Preparation Kit. Personal communication. Internet resources.

Contact for satalysis and biocatalysis solicitation: Linda Beth Schilling 301-975.2887 (phone) 301-926-9524 (fax) SCHILLIN@MICF.NIST.GOV

Date of last revision: September 22, 1995. 


\section{U.S. Department of Commerce}

National Institute of Standards and Technolory

Chemical Science and Technology Laboratory

Chemistry Butling, Rm. A317

Gaithersburg, MD 20899

\section{Contact: Dr. William Koch, Depury Director \\ Phone: $\quad 301-975-3146$ \\ Fax: $\quad 301-975-3845$ \\ E-mail: $\quad$ KOCH@MICF.NIST.GOV}

Description of agency involvement in chenical industry-related ReD:

The mission of the Chemical Science and Technology Laboratory is to perform research in measurement science, develop and maintain measurement methods, standards, and reference data; and develop models for chemical, bionolecular and physical properties and processes. The goals of the laboratory are to (1) establish the laboratory as the pinnacle of the traceability structure for measurement in chemisury, chemical engineering, and biotechnology; (2) assure that U.S. industry has access to accurate and reliable dath, models, and predictive algorithms; (3) anticipate and address next generation measurement needs of the nation; and (4) foster the development and irnplementation of advanced process technologies.

The laboratory is divided into six divisions: Biotechnology; Chemical Kinetics and Thermodynamics; Process Measurements; Surface and Microanalysis Science; Thermophysics; and Analytical Chemistry. In FY 94, the laboratory also had 73 active cooperative reseanch and development agreements (CRADAs) with other organizntions.

Amownt of funding awailable for chemical industry-related R\&D:

In both FY 94 and FY 95, approximate funding for the labortitory from all sources was $\$ 50$ million annually. The laboratory receives substantial funding from other federal agencies and private sector organizations in addition to general funding.

Length of invohement in chemicol industry-related ReD efforts:

The laboratory has been involved since its ereation in 1991.

Relationship to OIT programs (ff applicable): None.

Notes:

Sounces of information: $\quad$ NST Chenical Sclence and Technology Laboratory brochure. Chemical Science and Technology Loboratory 1994 Technical Activities (NISTIR 5584).

Personal communication. 
Division contacts: (all phone numbers are area code 301 and all email at MICF.NIST.GOV)

Biotechnology:

Chemical Kinetics and Themodynamics:

Process Merasurement:

Surface ard Microanalysis Science:

Thermophysics:

Analytical Chemistry:
Dr. Lura Poweli, 903-2627; POWELL@

Dr. Sharon Lias, 903-2562, SGL@

Dr. Gregory Rosasco, 903-2609, ROSASCOG@

Dr. Rance Velapoldi, 903-3917, VELAPOLOC

Dr. Richard Kayser, 903-2483, KAYSER@

Dr. Wiltie May, 903-3108, WEM@

Date of last revision: August 31, 1995. 
U.S. Depsrtment of Commerce

National Institute of Standards and Technology

Materials Science and Engineering Laboratory

Bldg. 223, Rm. B309

Gaithersburg, MD 20899

Contact: Dr. Kenneth L. Jewett, Scientific Assistant to the Director

Phone: $\quad 301-975-2608$

Fax: $\quad 301-926-8349$

E-mail: KENNETH.JEWETT@NIST.GOV

Description of agency invohement in chemical industrynelated R\&D;

The Materials Science and Engineering Laboratory (MSEE) seeks to be the central resource within the federal government in support of technology development in advanced materials and advanced processing of materials for application in the civilian econony. The mission of the MSEL is to stintulate the more effective production and use of materials by working with industry in the development and implementation of technology, measurements, and standards.

The MSEL has five operating divisions: Metallurgy, Cerranics, Polymers, Materials Reliability, and Reactor Radiation; along with an Office of Intelligent Processing of Materials.

Projects in various divisions have potential relevance to the chemical industry. Example project titles include:

- Molecular Dynamics of Replacement Refrigerants Encaged in Zeolites (Reactor Radiation)

- Magnetic Refrigeration (Metsilurgy)

- Ultrasonic Characterization of Materials (Materials Reliability)

- Pressure Dependence of the Phase Behavior of Polymer Blends (Potymers)

Amount of funding avaliable for chemloal industry-related R\&D:

The budget for the MSEL in FY 94 was \$62.5 mitlion, and in FY 95 the budget was $\$ 66.6$ million.

Length of involvement in chemical industry-related R\&D efforts:

The MSEL has been involved in related efforts since its inception.

Relationship to OIT prograns (ff applicable):

OIT contributed to a project entitled Intelligent Processing of Rapidly Solidified Metal Powders.

Noves:

Sources of information; Personal communication.

Moterials Sclence and Engineering Laboratory 1994 Amual Report (NISTIR 5577).

Other MSEL Technical Activity 1994 reports.

Internet resoltices.

Date of last reviston: September 12, 1995. 



\section{DEPARTMENT \\ OF \\ DEFENSE}

The Department of Defense is responsible for providing the military forces needed to deter war and protect the security of our country. Under the President, who is also Commander in Chief, the Secretary of Defense exercises authority, direction, and control over the Department, which includes the separafely organized military departments of the Amy, Navy, and Air Force, the Joint Chiefs of Staff providing military atvice, the unified combatant commands, and various defense agencies established for specific purposes. 
U.S. Department of Defense

Advanced Research Projects Agency

Defernse Sciences Office

3701 North Fairfax Drive

Arlington, VA 22203-1714

Contact: Dr. Lawrence H. Dubois

Phone: $\quad$ 703-696-2283

Fax: $\quad 703 \cdot 696-2201$

E-mail: $\quad$ LDUBOIS@ARPA.MIL

\section{Description of agency involvement in chemical industry-retated RAD;}

The Defense Sciences Office (DSO) is the most technically diverse office of the Advanced Research Projects Agency (ARPA), funding research and development on optical, electromagnetic, and structural materials and processing advanced energy and enviroamental technologies; applied and computationa! mathenatics; and defense health care technologies.

Primary areas of chemical industry-related R\&D emphasize the development of advanced membranes, solid oxide electrolytes, and catalysts for fuel cells; high conductivity polymer electrolytes for betteries; the development of erosion/corrosion resistant coatings; environmentally conscious methods of electronics systems manufacturing; and advanced waste destruction/reclarnation technologies. DSO is funding approximately $\mathbf{4 0}$ projexts in these areas. Sample project titles and participants include:

- Development of Direct Methapol Oxidation Fued Cells (Jet Propulsion Laboratory, Giner, Inc., Intemational Fuel Cells, Cuse Westem Reserve University)

- Li and Li-ion Battery Development (SAFT America, Ultralife, Electrofivel, A.D. Little, Alliant, University of Minnesota)

- Replacements for Electroplated Hard Chrome (BIRLNorthwestem)

- Advanced Processing of Printed Wire Boards (DuPont, Geargia Tech, IBM, Microelectronics and Computer Technology Corp., Micruelectronics Center of North Carolina)

- Reclamation of Cured Fiber Composites (Adherent Technologies)

- Hyorothermal Oxidation of Waste Materials (General Atomics, Foster-Wheeler, Stone \& Webster)

- Environmental Sensors (Loral, Hughes, General Atomies, Teledyne, Rockwell)

Amount of funding arailable for chemicul industry-related R\&D:

In FY 94, around \$40 million was authorized, atd it FY 95, around \$32 million was authorized.

Length of involvement in chented industryy-related R\&D efforts:

The materials chemistry, advanced energy, and environmental technologies progrems were begun at ARPA in earty 1988.

Relationship to OIT programs (ff applicable): None.

Notes:

Sources of information: Personal communication.

Date of lass revision: July $26,1995$. 


\section{U.S. Department of Defense \\ Advanced Research Project Agency \\ Technology Reinvestment Project \\ 3701 North Fairfax. Drive \\ Arlington, VA 22203}

Contact: Mr. H. Lee Buchanan III, Director

Phone: $\quad 703-696-2237$ (Buchanan)

Fax: $\quad$ 800-DUAL-U $\quad$ 703-696-2201

E-mail: Unknown

\section{Description of agency invotvement in chemical industry-retated RaD:}

The Technology Reinvestment Project (IRP) is a six-agency, dual-use technology investment effort that includes the Departments of Defense (Advanced Research Projects Agency, Army, Navy, Air Force), Commerce, Energy and Transportation, the National Science Foundation and the National Aeronautics and Space Administration. It was formed to execute eight statutory programs enacted by Congress in the Defense Technology Converșion, Reinvestment, and Transition Act of 1992. These eight programs have common requitements, including participation by "partnerships," cost sharing between those partnerships and the Federal Govemment, and a fooss on assisting small businesses and Defense-dependent businesses. It is the continuing mission of the TRP to stimulate the transition to a gnowing, integrated, national industrial capability which provides the most advanced, affordable, military systems and the most competitive commercial prodicts. The TRP fulfitls its mission throngh the application of Defeuse and commercial resources to develop dual-use technologies, to deploy manufacturing and technology assistance to smatl firms, and to establish education and training pnggrams that enhance U.S. manufacturing skills and target displaced Defense incustry workers.

The FY 95 solicitation requests Technology Reinvestment Project (TRP) Technology Development and Small Business Innovation Research (SBIR) Phase I proposals in the following daal use teclmology focus areas: (1) Affordable Advanced Controls Technologies, (2) Affordable Polymer Matrix Composites For Aiframe Structures, (3) Biological Sensors And Mnlti-Organ Diagnostic Screening, (4) Djgital Wsireless Communications And Networking Systems, (5) Operations Other Than War/Law Enforcentent, (6) Small Precision Optics Manufacturing Technology, (7) Microeiectromechanical Systems Applications, and (8) Other: All proposals in areas other than 1-7 will be cempeted as a separate, highly competitive category. Awards from the FY 94 solicitation include projects from a focus area on environmental sensors:

- E-SMART System for In-Situ Deteotion of Environmental Contaminants (General Atomics, Air Force/Armtstrong Lab, Georgia Tech, Isco, Photonic Sensor Systems, Science \& Engineering Analysis)

- Volatile Organic Compound Sensors, Communications, Processing, and Display (Hughes Aireraft, AAI-ABTECH, GM Hughes Electronics Research Laboratories, University of Pennsylvania)

- UV DIAL Lidar (OCA Applied Optics, Los Alsmos Science)

- Field-Deployable, Continuous Monitoring Mass Spectrometer (Teledyne Electronic Technologies; Oak Ridge National Lab; Monsento; Phillips Petroleum; Scientific Instrument Services; Synergist)

- IMAS: An Intelligent Modular-Auray System for the Monitoring of VOCs in the Environment (Tektronix; Battelle, Pacific Northwest Lab; Sandia Natjonal Lab; Sawtek) 
Amount of funding avallable for chemicol industry-related RED:

In FY 94, about $\$ 200$ million of awards were made. In FY 95, available finds for Technology Development and SBIR Phase I projects were around $\$ 160$ million and $\$ 10$ million, respectively.

\section{Length of inwolvement in chemical industry-related R\&D efforts:}

The first TRP solicitation occurred in FY 93.

Relationship to OT prograns (ff applicable):

DOE is one of five non-DOD agencies administering projects awarded by the TRP+ OIT has administered a project with the Maine Metal Products Association.

Notes:

Sources of information: Personal communication. Internet resources.

Date of last revision: September 7, 1995. 
U.S. Department of Defense

Department of the Air Force

Office of Scientific Research

Directorate of Chemistry and Life Scieaces

110 Duncan Ave., Suite B115

Bolling Air Force Base, DC 20332-000]

Contat: Dr. Mike Berman

Phone: $\quad 202-767-4963$

Fax: $\quad 202.767 .4961$

E-mail: BERMAN@AFOSR.AF.MIL

Desatpion of agericy involventent in chemical industry-related R\&D:

The Office of Scientific Research directs the Air Force's entire basic research program. Through grants to university scientists, contracts for industry research, cooperative agreements, and support for basic research in Air Force Laboratories, the office funded approximately 1,300 grants and contracts in FY 94, totaling more than $\$ 200$ million to about 350 academic instinutions and industrial firms.

The Chemistry and Life Sciences Directorate within the Office of Scientific Research has programs in the following areas:

- Chemical Reactivity and Synthesis - Polymer Chemistry

- Inorganic Materials Chemistry - Theoretical Chemistry

- Molecular Dynamics Nentoscience

- Chronobiology - Perception and Recognution

- Spatial Orientation

- Bioenvironmental Sciences

- Cogation

- Organic Matrix Composites.

Amount of funding awailable for chemical industry-related R\&D:

In FY 94, available related funding was approximately $\$ 23.1$ million, and in FY 95, available related funding was approximately $\$ 23.4$ million.

Length of hwotvement in chemical industry-related $R$ \&D eforts:

The directorate has been involved in chemical industry-related efforts for over 30 years.

Relationship to OTT programs (if applicable): None.

Notes:

Sources of information: Personal communication.

Research Interests and Broad Agency Announcement 95-1 of the Atr Force Office of Scientific Research (AFOSR Pamphlet 70-1).

Internet resources.

Date of last revision: September 8, 1995. 
U.S. Department of Defense

Department of the Air Force

Small Business Innovation Research Program

HQ AFMC/STXB .

Chidlaw Stret, Suite 6

Wright-Patterson Air Force Base, OH 45433-0336

Contact: Ms. Jill Dickman, Ait Force SBIR/STTR Program Executive

Phone: $\quad 800-222-0336$

Fax: $\quad$ 513-476-1086

E-mail: $\quad$ Unknown

Dexcription of agency innotwoment in chemical industy-related RQD:

The Air Force Small Business Innovation Research (SBIR) program finds Phase I research up to $\$ 100$ thousand and Phase II research up to $\$ 750$ thousand for qualified small businesses. SBIR contracts are awarded competitively besed on scientific and technical merit Air Force SBIR topics come from an extensive national resource of four major Air Force baboratories along with a number of smaller research centers and logistics organizations located throughout the United States. Sample topies areas for the FY 96 solicitation include:

- Themmal-Barrier and Comosion-Protective Nano- and Micro-Laminated Ceramic Coatings

- Software for Computational Chemistry

- Chemical Reactor Technology

- Low-Temperature Treatrient Technologies for Dilute Gaseous Effluents

- Volume Reduction of Aircraft Depainting Wastes

- Remediation Technology for Low Hydrantic Conductivity Soils

- Treatment of Trichloroethylene Using Dual Co-Substrates

- Role of Iron in Anaerobic Degradation of Fuel Hydrocarbon

Amownt of funding arallable for chemicol industonrelated R\&D:

In FY 93, the Air Force SBIR budget was over \$130 million.

Length of involveneat in chemical industny-related R\&D effors:

The SBIR progran was created in 1982.

Relationshtp to OTT programs (f applicable): None.

Notex:

Sources of information: $\quad$ Air Force SBIR, An Opportumity for Small Busthess. Intermet resources.

Date of last reviston: September 29, 1995. 
U.S. Department of Defense

Department of the Army

Army Research Laboratory

AMSRL-TT-TA

2800 Powder Mill Rd.

Adelphi, MD 20783-1197

Contact: $\quad$ Mr. $\mathbf{R}$. Michael Claffy

Phone: $\quad 301-394-3098$

Fax: $\quad 301-394-5818$

E-mail: $\quad$ MCLAFFY@ARL.MIL

Description of agency bwolventut in chembat industry-telated R\&D;

The Army Research Laboratory was created as a result of the Base Realignment and Closure 91 Commission recommendation and subsequent Congressional and Presidential approval. The lab consists of 12 directorates, including 11 technology-oriented divectorates, located at several geographic sites throughout the country.

The materials directorate has areas of expertise in adhesives, polymers/plastics, coalings, and comosion prevention, among other items. Other directorates have expertise in other areas. Sanple technology transfer opportunities include:

- Advanced Engine Thermoplastics

- Aerosol Diagnostics Using Laser-Based Methods

- Coatings Resistant to Chemical Agents

- Halon Alternatives for Fire Suppression

- Soldering Without Flux.

In addition, the lab also operates the Ammy's Small Business Innovation Research (SBIR) program.

Amount of fundlig awallable for chemloul industry-related RAD:

The total R\&D badget for the lab was $\$ 283$ million is FY 95.

Length of involvament in chemical industry-related R\&D effork: Unknown,

Relationshlp to OTT prograns (f applicabie): None.

Noles:

Sources of information: Personal communication. Internet resources.

Date of last revirion: September 29, 1995. 
U.S. Departinent of Defenise

Department of the Amy

Army Research Office

Chemical and Biological Sciences Division

P.O. Box 12211

Research Triangle Park, NC 27706-2211

Contact: $\quad$ Dr. Robett Shaw, Director

Pboal: $\quad$ 919-549-4293

Fax: $\quad 919-549.4288$

E-mail: $\quad$ Unknown

Description of asency involvement in chentical industry-related R\&D;

The Amy Research Office is responsible for basic research efforts in support of the Anny and its requirements. Programs included efforts in biochemistry, polymer chentistry syuthesis, electrochenisstry, colkid chenistry, organic chemistry, and physical chemistry.

Amount of funding awilable for chemical indestry-retated ReD:

In FY 94, approximately $\$ 9$ million was authorized for chemistry reseanch efforts.

Langth of inwotwement in chemical indwory-related R\&D efforts:

The Army Research Office has been involved in similar efforts for several docades.

Relationskip to OTT prograns (ff appilcable): None.

Notes:

Soures of information: Personal communication.

Date of last revision: September 29, 1995. 


\section{U.S. Department of Defense \\ Department of the Navy \\ Office of Naval Research \\ 800 North Quincy Stret \\ Arlington, VA $22217-5660$}

\section{Contact: Dr. Ronald A. DeMarco \\ Phone: $\quad 703-696-5075$ \\ Fax: $\quad 703-696-6887$ \\ E-mail: $\quad$ DEMARCR@ONRHQ.ONR.NAVY.MIL}

\section{Description of agency involvement in chemicul industry-related R\&D:}

The Office of Naval Research supports basic research, exploratory development and technology development reseanch effiorts in support of the missions required of the Navy and Marine Corps. Chennical research is focused at universities, Navy centers, and industrial laboratories.

Primary areas of chemical research ane focused on synthesis and characterization of new cornpoumds/precursors and understanding kinetics and mechanisms relating to chemical processes of interest. Areas of research are limited to Physical Chemistry, Polymer Chemistry, Solid State and Surface Chemistry, Electrochemical Sciences and Technology, and Organic Chemistry. The Office of Naval Research currently funds approximately 180 reseanch efforts in areas focusing on:

- Chemistry/physics of sliding contact

- Optociectronic polymers

- Small domains

- Chemical compatibility

- Organometallic routes to new materials

- Marine bioadhesives/fouling release coatings

- Molecular-level understanding of lubrication

- Chemical interfaces
Membranes

Electrostrictive polymers

Advanced processing

Polymer surface science

Interfacitil structure and dynamics

New electrode materials

This-iultra-thin film science

Supranolecular assemblies/devices

Amount of funding avallable for chemical industry-related ReD:

The Office of Naval Research provided approxituately $\$ 30$ million for support of basic research efforts in chemistry in FY 94 and FY 95.

Length of imolvenent in chemical industhy-related R\&D efforts:

The office was established by Congress in 1946. Basic research in chemistry has been supported over the years; curtent applications of chemical systems to Navy*relevant areas, such as acoustic materials, electronic materials, semi-superconductor materials, minimally ddhesive materials, IR materisis, polymer composites, power sources, tribjology, adhesion, and thin-film growth are under investigation.

Relotionship to OrT programs (ff applicable): None.

Noses:

Sources of information: Personal communication.

Date of last revision; September 27, 1995. 
U.S. Department of Defense

Department of the Navy

Office of Naval Research

Small Business Infovation Research Program

$800 \mathrm{~N}$. Quincy St, ONR 362 SBIR

Axlingtom, VA 22217-5660

Contact: Mr. Vincent Schaper, Program Officer

Phone: $\quad 703-696-8528$

Fax: $\quad$ 703-696-4884

E-mail: $\quad$ SCHAPERV@ONRHQ,ONR.NAVY.MIL

Description of agency inyolvement is chentical industry-related R\&D:

Through the Department of the Navy's Small Business Imovation Research (SBIR) Program, small businesses have the opportumity to address neval needs in more than 30 science and technology areas. SBIR provides the fleet with innovative advances in technology developed by small firms that have the courage, drive, and flexibility to assume risks, develop niches, and generally compete in areas less atractive to larger firms. SBIR participants benefit both from program awards as well as the further development and commercialization of the resulting products.

Special consideration is given to research topies that further one of more of the following critical technologies, as tdentified by the National Critical Technologies Panel.

Science

Compoter Sciences

Mathematics

Cognitive and Neural Sciences

Biology and Medicine

Terrestrial Sciences

Atmospheric and Space Sciences

Ocean Sciences

Chemistry

Physics

Electronics

Materiats

Mechanics

Environmental Sciences

Manufacturing Sciences
Technology

Aerospace Propulsion and Power

Aerospace Vehicles

Chemical and Btological Defense

Command Control and Communication

Computers

Conventional Weapons

Electron Devices

Electronic Warfare

Environmental Quality and Engineering

Fuman-System Interface

Manpower and Personnel

Materials and Structures

Medical

Sensors

Surfacelundersurface Vethicles

Software

Training Systems 
The program receives topics from various parts of the Navy in science and technology areas. Over 100 topics were solicited in both FY 94 and FY 95 . Sample topic areas for FY 95 include:

- Biofilters for Reduction of Gaseous Emissions

- Modeling Characteristics for Volumetric Explosives

- Near Infrired Fhorophores for Advanced Array Biosensors

Sample awards from FY 94 include:

- Novel Membrane-Based System for Shipboard Treatment of Gray-Water and Oily Waste Water

- Low-Cost Chemically Bonded Ceramic Prototype Tooling for Fabrication of Composites

- Deterioration Sensors of Hazardous Material Containers

- Electrochemical Concentration and Purification of Spent Sodinm Bicarbonate Błasting Media

- Advanced Membrane System for Graywater Treatunent

Amount of funding avaliable for chandcal hadustry-related ReD:

Total funding for all areas of the Navy SBIR in FY 95 was $\$ 101$ million.

Length of involvement in chemical industry-retated R\&D efforts:

The Navy has been participating in SBIR solicitations since the early 1980 s.

Relationship to OIT programs ( $G$ applicable): None.

Notes:

Sources of information: Personal communication.

Internet resources.

Date of last reviston: August 11, 1995. 


\section{U.S. Department of Defense}

Strategic Environmental Research and Development Program

SERDP Program Office

901 N. Stuart St, Ste. 303

Aslington, VA 22203

Contaxt: Ms, Amy Levine

Phone: $\quad$ 703-696-2117

Fax: $\quad$ 703-696-2114

E-mgil: $\quad$ ALEVDNE@NS1.SEROP.GOV

\section{Description of atency involvement in chemicol industry-related R\&D.}

The Strategic Environmental Research and Development Program (SERDP) is a Congressionally mandated program (Public Law 101-510) addressing environmental matters of concern to the Department of Defense (DOD) and the Department of Energy (DOE). The program is jointly managed by DOD, DOE, and the Environmental Protection Agency, with participation by other federal agencies.

Among other activities, the program provides for the identification and support of programs of basic and applied resesireh, development, and demonstration of technologies usefil to:

- facilitate environmental compliance, remediation, and restoration activities;

- minimize waste generation, including reduction at the source;

- substitute use of nonhazardous, nontoxic, nonpolluting, and other envircnmentally sound materials and substances;

- provide for the identification and support of research, development, and application of other technologies developed for national defense purposes;

- conduct joint research, development, and demonstration projects relating to innovative technologies, management practices, and other approaches; and

- provide for the identification of, and planning for the demonstration and use of, existing environmentaliy sound, energy-efficient technologies developed by the private sector.

The program currently has six major thrust areas: cleanup, compliance, conservation, energy conservation/renewable resources, global environmental change, and pollution prevention. By FY 97 , the global environmental change and energy conservation/renewable resources areas will be eliminated. In FY 94, the progran funded approximately 125 projects in all areas. Sample project tities include:

- Removil of VOCs from Contaminated Groundwater and Soils by Pervaporation

- Catalytic In Siar Treatment of Chlorinated Solvents

- Supercritical Water Oxidation of Organic Wastes

- Clean Liquid Fuel from Biomass and Carbonaceous Wastes

- Life Cycle Engineering and Design Program

- Solvent Substiution and Low VOC Cleaners

- Chemistry of Halon Substiturtes

- Continuous Aqueous Cleaning to Eliminate Ozone-Depleting Compounds

- Non-Ozone Depleting Refrigerants for Navy Chillers 
Amonat of funding avallable for chemical industry-reluted ReD:

The FY 93 appropriation for the SERDP was $\$ 180$ million, the FY 94 appropriation for the SERDP was $\$ 160$ million, and the FY 95 appropriation was $\$ 61.9$ million.

Length of inwotvement in chemical industry-related R\&D efforts:

The SERDP was enacted by Public Law 101-510 in 1990.

Relationship to OIT prograns (ff applicable):

The Department of Energy and several of the national laboratories are participating in the program.

Notes:

Sources of information: Personal communication.

1994 Amtual Report and Fire-Year (1994-1998) Strategic Investment Plan, Strategic Envirommental Research and Development Program.

Other contact: Mr. Blake Henke, SERDP Support Office, 703-506-1400

Dote of last revision: August 23, 1995. 



\section{DEPARTMENT \\ OF ENERGY}

The Departrnent of Energy provides the framework for a comprehensive and balanced national energy plan through the coordination and administration of the energy functions of the Federal Government. The Department is responsible for long-term, high-risk research and development of energy technology, the marketing of Federal power; energy conservation; the nuclear weapons prograrr; energy regulatory programs; and a central energy data collection and apalysis program. 


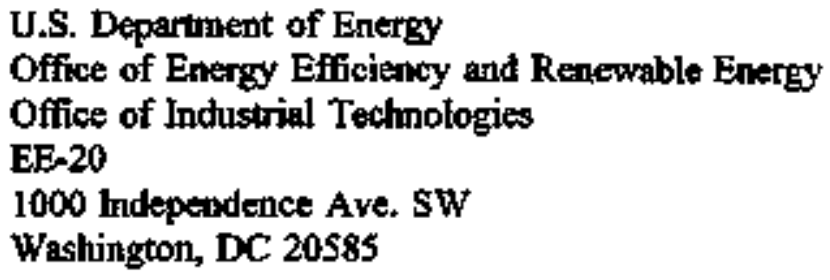

Contact: Mr. Bruce Cranfond, OrT Chemical Industry Tean Leader

Phone: $\quad 202-586-9496$

Fax: $\quad$ 202-586-3237

E-mail: $\quad$ BRUCE.CRANFORD@HQ.DOE.GOV

\section{Description of agency involvement in chenical industry-reloted R\&D:}

The Office of Industrial Technologies (OIT), through partnerships with industry, government, and nongovernmental organizations, develops and delivers advanced energy efficiency, renewable energy, and pollution prevention technologies for industrial applications. Primtary areas of chemical indusky-related R\&D emphasize increasing chemical conversion efficjency, reducing fossil firel dependence, reducing waste product generation, increasing conversion and recycling of waste products, ind better utilizing waste heat. The Office of Industrial Technologies is currently funding approximately 45 projects in these areas. Sample project titles include:

- Bioprocessing (Oak Ridge National Laboratory, Dow, 3M, AlliedSignal)

- Inorganic Polymer Membranes (Idaho National Engineering Laboratory, Union Carbide, Media and Process Technology)

- Auto Shredder Residue (Argonne National Loboratory, Alter Trading Co.)

- Carpet Waste to Caprolactam (National Renewable Energy Laboratory, AlliedSignal)

- Bionass to Lactic Acid (National Renewable Energy Laboratory, Golden Technologies Company)

- Novel Selective Surface Flow Membranes (Air Products and Chemicals)

- Alternative Feedstocks (Argonne Natjonal Lab, Idalso National Engineering Lab, National Renewable Energy Lab, Oak Ridge National Lab, Pasific Northwest Lab)

In addition, OIT also funds research through the National Industrial Competitiveness through Energy, Environment, and Economies (NICE ${ }^{3}$ ) Program, which is a joint grant program between the Department of Energy and the Environmental Protection Agency. The overall goal of the NICE Program is to improve indastrial energy efficiency, reduce industry's costs, and lower emissions to the environment. The program solicits projects annually, and provides grants which fiond up to $50 \%$ of the total project cost, with a maximum award of around $\$ 400,000$. The chemical industry (SIC 28) is a priority area for the program. The program has funded around 40 projects since its inception, Sample project titles from previous solicitations and participants include:

- Ultrasonic Tank Cleaning (DuPont Merck, New Jersey Dept. of Energy and Eavironmental Protection)

- Reclaim and Retse Waste Water (PPG Industries, Ohio Dept, of Development)

- Methanol Recovery Process (FMC Corp., Texas Water Commission)

- Use of Recovered Plastics in Manufacturing of Durable Goods (MBA Polyners, California Energy Commission)

- Fuel-Based Nitrogen Generator (Industrial Gas Technologies Commercialization Center, Ohio Dept. of Development) 
Also, OIT's Petrolerm Refining Team conducts research in the areas of novel process development, process modeling, catalysis, and separations. Finally, OIT has many cher programs that fund research in such areas as advanced matterials, heat exchangers, and cogeneration.

Anount of funding avallable for chemtod industry-related R\&D:

In FY 1995, approximately $\$ 23$ million has been authorized by OIT for chemical industry efforts. The NICE' program made awards of approximately $\$ 4.6$ million in FY 95.

Length of involvement in chemlod industry-related R\&D efforts:

OIT was formed in 1976. The chemical industry has been a focal point since its formation due to the high energy use and intensity of the chemical industry. The NICE ${ }^{3}$ program began in 1991.

Relationship to orT progronts (ff applicable); n/a.

Notes: (all area code 202 and e-mail at HQ.DOE.GOV)

Other OIT Chemical Industry Team meinbers:

- David Boron, 586-0080, DAVID.BORON@

- Doug Gish, 586.1741, DOUG.GISH@3

- Ehr-Ping Hatng Fu, 586-1493, EHR.PING.HUANGFU@

- Gloria Kulesa, 586-8091, GLORIA.KULESA(a)

- Stuart Natof, 586-2370, STUART.NATOF@

* Charles Russomanmo, 586-7543, CHARLES.RUSSOMANNO@

- Alan Schroeder, 586-1641, ALAN.SCHROEDER@ (also the NICE ${ }^{3}$ contact)

- Brian Volintine, 586-1739, BRIAN.VOLINTTNE(9)

Petroleum Refining Team Contact:

- Dan Wiley, 586-2099, DAN.WLLEY@

Other OIT Contacts:

- Tom Foust, 586-0t98, TOM.FOUST@ (Forest Products Team)

- Doug Kaempf, 586-5264, DOUG.KAEMPF@ (Metals Casting Team)

- Susame Leonand, 586-6108, SUSANNELEONARD@ (Glass Team)

- Matt McMonigle, 586-2082, MATT.MCMONIGLE@ (Aluminum Team)

- Scot Richlen, 586-2078, SCOTT.RICHLEN (2) (Steel Team)

- Simon Friedrich, 586-6759, SIMON.FRIEDRICH@ (Municipal Solid Waste)

- Stan Blazewicz, 586-4679, STAN.BLAZEWCZ@(Cogeteration)

- Charles Sorrell, 586-1514, CHARLES.SORRELL@ (Advanced Materiais)

- Gideon Varga, 586-0082, GIDEON.VARGA@ (Combustion)

- Frank Wilküs, 586-1684, FRANK.WILKINS@ (Solar Industrial)

- Theo Johnson, 586-6937, THEODORE.JOHNSON@ (Sensors)

- Paul Scheihing, 586-7234, PALL_SCHErHING@ (Motor Challenge)

- Chuck Glaser, 586-1298, CHARLES.GLASER (Industrial Assessment Centers)

- Lisa Getman, 586-2487, LISA,GERMAN@ (Technology Transfor)

Dave of tost revision: September 7, 1995. 
U.S. Department of Energy

Office of Energy Efficiency and Renewable Energy

Ofjice of Building Technologies, EE-422

1000 Independence Ave. SW

Washington, DC 20585

Contact $\quad$ Mr. William Noel (nefrigerants)

Phore: 202-586-6149

Fax: 202-\$86-1628

E-mail: WILLAM.NOEL@HQDOE.GOV
Mr. Ronald Fiskum (absorption fluids)

202-586-9154

202-586-1628

RONALD.FISKUM@HQ.DOE.GOV

Description of agency involvement in chenical industry-related R\&D:

The Office of Building Technologies (OBT) operates a strategic array of programs, including research and development of advanced technologies and construction practices; collaborative prograns with industry and consumers to deploy high-efficiency techmologies into the commercial and residential markets; and national standards for appliances and buildings to ensure that they meet minimum energy efficiency levels. Research areas include lighting (e.g., sulfur lanps), advanced insulation (e.g., evacuated powder panels), windows (e.g., argon or krypton filled double-pane), and appliances (e.g., refrigerators and heat pumps).

The primary emphasis on chemical industry-related research within OBT is the replacement of refrigerants (and insulation blowing agents) containing chlorofluorocarbons (CFCs), and development of advanced alksorption fluids for thermally activated heat pumps. CFC alternatives research covers materials compatibility and properties with chlorine-free (bydrofluorociartions) refrigerants, blends, and lubricents. Absorption fluids research involves analysis and cesting of novel qutaternary ammonia-based and multi-component water-based fluids for heat pumps.

Amount of funding avallable for chemical industhy-related R\&D;

Approximately \$2.9 million was authorized for these efforts in FY \$4, and approximately \$2.4 million was authorized for these efforts in FY 95.

Length of hwolventem in chentical industry-related RaD efforts:

The Office of Building Technologies has been involved in chemical industry-related research activities since the early 1980's.

\section{Relationship to OTT programs (ff applicable):}

OBT and OIT are located within the same parent organization in DOE.

Notes:

Sources of information: Personal communication.

Date of last reviston: August 16, 1995. 


\section{U.S. Department of Energy}

Office of Energy Efficiency and Renewable Energy

Office of Transportation Technologies, EE-30

1000 Independence Ave. SW

Washington, DC 20585

$\begin{array}{ll}\text { Contact: } & \text { Mr. John Ferrell } \\ \text { Phone: } & 202-586-6745 \\ \text { Fax: } & 202-586-9815 \\ \text { E-mail: } & \text { JOHN.FERRELL@HQ.DOE.GOV }\end{array}$

\section{Dexcription of agency involvement in chemical industry-related RED;}

The Biofiels Systems Division conducts research, development and demonstration activities geared toward the commencialization of clean biontass-based altemative fuets to displace petroleum-derived fuels for use in the transportation sector. The program supports technology development in two specific areas; biomass feedstock preparation and conversion of feedstocks to transportation fuels including ethanol, methanol, reformulated gasoline components, biocrude derivatives and biodiesel.

The Biofiels Systerns Division currently funds a strong in-house research effort which is being conducted at two national labs, as well as approximately 70 subcontracts at numerous university and industrial laboratories and consortia throughout the country and the program supports work in three Cooperative Research and Development Agreenents (CRADAs) with indinstry. The R\&D activitios ineluded laboratory bench scale research as well as pilot scale activities. Sample project titles and participants include:

- Fermentation Technology: \$train Development (National Renewable Energy Laboratory, Purdue University, University of Wisconsin)

- Process Applications: DeveJop Afternative Pretreatment Methods (National Renewable Energy Laboratory, Colonado State University, Purdue University, University of Califonia, Auburn University)

- Biocrude Testing (National Renewable Energy Laboratory, University of Utah, University of Iowa)

- Populus Physiology and Biotechnology (Oak Ridge National Laboratory, U.S. Department of Agriculture-North Carolina Forest Experimental Seation)

Amount of funding awailable for chemical industry-related R\&D:

In FY 94, approximately \$35 million was authorized, and in FY 95, approximately \$34 million was authorized.

Length of involvement to chemical indestry-related ReD efforts:

The Biofuels Systems Division of the Office of Transportation Technologies has focused on the production of cleaner buming, domestically produced binmass derived transportation fuels for the past decade. Biomass to ethanol has been determined to bave the best near term potential, particularly for the oxygenate markets, with peat fuels as a longer tern goal. 


\section{Relationshtp to OTT programs (ff applicable):}

The Biofirels Systems Division of the Office of Transportation Technologies, along with the Alternative Feedstock Division of the Office of Industrial Technologies, coordinated funding of the Consortium for Plant Biotechnology Research in FY 95, broadening the support for Energy from Biomass to include support of chemicals produced from Biomass feedstocks. The two programs maintain communication on program diraction and projects that are of mutual interest.

Noles:

Sources of information: Personal communication.

Date of last reviston: August 1, 1995. 


\section{U.S. Department of Energy}

Office of Energy Efficiency and Renewable Energy

Office of Utility Technologies, EE-142

1000 Independence Ave. SW

Washington, DC 20585

$\begin{array}{ll}\text { Contact: } & \text { Mr. Neil Rossmeissl } \\ \text { Phone: } & 202-586-8668 \\ \text { Fax: } & 202-586-0784 \\ \text { E-mail: } & \text { NELL.ROSSMEISSL@HQ.DOE.GOV }\end{array}$

\section{Description of agency inwolvensent in chenical industo-related R\&D:}

The Office of Utility Technologies (OUT) leads the federal government's effort to help America's electric power producers develop clean, renewable, and more econonicil forms of energy. The office's Hydragen Program, within the Advenced Utility Concepts Division, is partmering with industry through direct cost-shere and cooperative nesearch and development agreemersts (CRADAs) with the national laboratories to develop hydrogen production, storage, transportation, and utilization technologies for the future use of hydrogen as an energy carrier and fuel.

The early marikets for hydrogen are as an industrial gas, in fertilizer and chemical production and to the upgrade of petroleum products. The Hydrogen Program has placed priority on hydrogen production and storage R\&D projects. Although the program's goals are the use of hydrogen as an energy cerrier and fuel, there are existing production and storage projects which are chemical-industry related in the present hydinogen market. Projects and participants include:

- Sorption Enhanced Reaction Process for Production of Hydrogen (Air Products and Chemicals)

- Conversion of Municipal Solid Waste to Hydrogen (Lawrence Livernore National Laboratory, Texaco)

- Solar Photochemical Production of $\mathrm{HBr}$ from Bromine and Steam for Ofi-Peak Electrolytic Hydrogen Production (Solar Reactor Technologies)

- Photoelectrochemical Hydrogen Production (University of Hawaii, National Renewable Energy Laboratory, Energy Conversion Devices, Solarex)

- Development of Solid Electrolytes for Water Electrolysis at Higher Temperatures (Florida Solar Enerby Center)

- Biomass to Hydrogen via Fast Pyrolysis and Catalytic Steam Refoming (National Renewable Energy Laboratory)

- Improved Metal Hydride Technology for the Storage of Hydrogen (Energy Conversion Devices, University of Michigan, Engineering Consultants)

- Hydrogen Transport and Storage in Engineered Microspheres (Lawrence Livermore National Laboratory, W.J. Schafer Associates)

- Polyhydride Complexes for Hydrogen Storage (University of Hawaii)

- Microporous Materials for Hydrogen Storage (Sandia National Laboratories, Westvaco, Amoco)

Amount of fundthg avallable for chemical industry-retoted ReD:

In both FY 94 and FY 95, about \$10 million was authorized annually for the Hydrogen Program. 


\section{Length of inwotvenent in chemical indistry-related R\&D efforts:}

DOE has sponsored hydrogen-related research since the early 1970's. The curnent Hydrogen Program was authorized in 1990 by the Spark M. Matsunaga Hydrogen Reseanch, Development and Demonstration Act.

\section{Relationshlp to OIT programs (if applicable):}

OIT supports several hydrogen production projects and participates in the Hydrogen Energy Coordinating Committee. Also, OIT and OUT ate located in the sarne parent organization at DOE.

\section{Notes:}

Sources of information: Personal communication.

Date of last revision: September 12, 1995. 
U.S. Department of Energy

Office of Defense Programs

Office of Economic Competitiveness

DP-14

1000 Independence Ave. sw

Washington, DC 20585

Contact: $\quad$ Mr. Tom D'Agostino

Phone: 202-586-7909

Fax: $\quad 202-586-1057$

E-mail: THOMAS.D'AGOSTINO@DP.DOE.GOV

Dexcription of agency invohement in chentcal tudustry-related ReD:

The Office of Economic Competitiveness (DP-14) supports, in cooperation with other organizations, R\&D programs that enthaxe the science and technology base and core competencies necessary to achieve the national secturity mission and contribute to U.S. industrial competitiveness. Technology pertuerships of interest to the chemical industry are is the areas of computer architecture and control, energy efficiency, reducing waste product generation and improvements in safety, health and monitoring. The Office of Economic Competitiveness is currently fundirg approximately 30 projects. Sample project titles and participants include:

- Open Tube Solld Phase Extractor (Los Alamos National Laboratory and Restek Corp.)

- Field-Portable Chemical Analysis Instrument (Pinellas Plant and Life Sciences, Inc.)

- Environmentally Conscious Closed-Loop Aqueous and Semi-Aqueots Cleaning Systems for

Defluxing (Kansas City Plant and American Technical Ceramics Corp.)

- Subsurface Flow and Chemical Migration (Lawrence Livermore National Laboratory and Intermational Technologies Corp.)

Amownt of fanding avallable for chemical indastry-related KeD:

In FY 95, approximately $\$ 11$ million is authorized and in FY 96, $\$ 7.5$ million is planned.

Length of involvenent in chemical industro-related RED efforts:

The Office of Economic Competitiveness has been involved in technology partnerships with industry and other non-federal organizations sirce 1991.

Retationship to OrT prograns (ff applicable):

The interaction between the Office of Eocnomic Competitiveness and the Office of IndustriaI Technologites hes been on a level of information exchange on projects of mutual interest.

Notes:

Sources of information: Personal communication.

Dofe of las revision: July 12,1995 . 
U.S. Department of Energy

Office of Energy Research

Basic Energy Sciences

Advanced Energy Projects Division, ER-33, GTN

1000 Independence Ave. SW

Washington, D.C. 20585

Contact: Dr. Walter M. Polansky, Director

Phone: $\quad 301-903-5995$

Fax: $\quad 301-903-6067$

E-mail: WALT. POLANSKY@MAlLGW.ER.DOE.GOV

Desctiption of agency involvement in chemical industry-velated RAD;

The Division of Advanced Energy Projects (AEP) provides support to explore the feasibility of novel, energy-related concepts that evolve from advances in basic research. These concepts are typically at an early stage of scientific definition and, therefore, are premanure for consideration by applied research or technology development programs. The AEP also supports high-risk, exploratory concepts that do not readily fit into a program area but could have several applications that may span scientific disciplines or technical areas.

The Division provides a mechanism for converting basic research findings to applications that eventually could impact the Nation's energy economy. AEP does not support evolutionary research or large scale demonstration projects. Technical topies include physical, chemical, materials, engineering, and biotechnologies. Projects can involve interdisciplinary approaches to solve energy-related problems. Projects supported by the Division arise from unsolicited ideas and concepts strbmitted by researchers. The porfotio of projects is dynamic and reflects the broad role of DOE in supporting R\&D for improving the Nation's energy outlook. FY 94 projects include the following topical areas:

- Novel Materials for Energy Technology

- Renewable and Biodegradable Materials

- Exploring Uses of New Scientific Discoveries

- Altemate Pathways to Energy Ethiciency

- Alternative Energy Sonrces

- Innovative Approaches to Waste Treatment and Reduction

In FY 94, the program was composed of 53 projects, 13 of which were new in FY 94. Sample project titles and perticipants include:

- Solar Detoxification of Aquatic Systems with Porous Photocatalysts (Brocklyn College of City University of New York)

- Biocatalytic Design by Chemical Modification (Oak Ridge National Laboratory)

- Zeolite Catalysts in Conversion of Cellulosics (Pundue University)

- Cationically Polymerizable Monomers Derived from Renewable Sources (Rensselaer Potytechnic Institute)

- Synthesis of New High Performance Lubricants and Solid Lubricants (University of Texas-Austin)

- Supersonic-Mixing, Shock-Wave Reactor An Innovative Approach for Efficient Chemical Production (University of Washington)

- Two-Dimensional Synthesis: Ultarthin Porous Mernbranes (University of Colorado) 
Amount of funding avallable for chemical industry-retated RAD:

AEP funding in FY 94 and FY 95 was around \$11 million. Projects are supported for a specified period of time, which typically does not exceed three years. In FY 1994, the average annual finding bevel for an AEP project was $\mathbf{\$ 2 9 9 , 0 0 0}$. It is expected that, following AEP support, esch concept will be sufficiently developed and prowising to attract further funding from other sources in order to realize its full potential.

Length of inrolvement in chemical industry-reloted R\&D efforts:

The Division of Advanced Energy Projects was fomed in the early 1980 s.

Relationship to OIT prograns (ff applicable): None.

Notes:

Sources of information: Personal communication. Internet resources.

Date of lase reviston: September 8, 1995. 
U.S. Departunent of Energy

Office of Energy Research

Office of Basic Energy Sciences

Chemical Sciences Division

ER-14

19901 Germantown Rd, MS G236

Germantown, MD 20585

Contact $\quad$ Dr. Robert Marianelli, Director

Phone: $\quad 301-903-5804$

Fax: $\quad 301-903-4110$

E-mail: ROBERT.MARIANELLI@MAILGW.ER.DOE.GOV

Description of agency inwolvenam in chemical indtustry-related ReD:

The Division of Chemical Sciences supports basic research at universities, DOE national baboratories, and ather eppropriate organizations for the purpose of providing the knowledge required to develop energy technologies that meet national goals of energy efficiency, public health and safety, environmental protection and restoration, and conservation of natural resources. Projects supported by the Division are selected for relevance to these goals and for scientific excellence as judget by peer review.

In FY 94, the division funded approximately 450 projects. There are eight elements in the division. These elements and their approximate number of projects are as follows: Photochemical and Radiation Sciences (78); Chemical Pbysics (83); Atomic Physics (46); Chemical Energy (110); Separations and Analysis (61); Heavy Element Chemistry (10); Chenical Engineering Sciences (26); and Advanced Battery Technology (26).

Sample project titles and participants include:

- Organic Photochenical Processes (University of Notre Dame)

- Chemical Structure and Dynamics (Pacific Northwest Laboratory)

- Fluid Catalysis (Argonne National Lahoratory)

- Chernical and Physical Primciples in Multiphase Separations (Oak Ridge National Laboratory)

- Solid-State, Surface, and Catalytic Studies of Oxides (Northwestern University)

- Mechanisms of Gas Permeation through Pobymer Menbranes (Syracuse University)

Amotwat of funding available for chemicel industry-related R\&D:

In FY 94, the Chemical Sciences Division was autharized approximately $\$ 158.9$ million. In FY 95, the division was authorized approximately \$159.6 million.

Length of inwohement in chemical industry-dated ReD efforts:

Research has been conducted for arond 25 years with impacts on the chemical industry.

Relationship to OIT prograws (f) applicable):

No formal programmatic relationship, bowever, there have been joint plannirg activities between Energy Research and OIT. 


\section{Notes:}

Sources of information: Personal communication.

Sumatarles of FY 1994 Research in the Chemical Sciences, U.S. Depertment of Energy (DOE/ER-0144/12).

Intermet resources.

Date of lass revision: August 21, 1995. 


\author{
U.S. Department of Energy \\ Office of Energy Reseirch \\ Basic Energy Sciences \\ Energy Biosciences Division, ER-17 \\ 19901 Germantown Rd. \\ Germantown, MD 20874
}

$\begin{array}{ll}\text { Contact: } & \text { MF. Greg Dilworth, Acting Director } \\ \text { Phone: } & 301-903-2873 \\ \text { Fax: } & 301-903-1003 \\ \text { E-mail: } & \text { GREG.DILWORTH@OER.DOE.GOV }\end{array}$

Description of agency involvement in chemicul industry-reloted R\&D;

The Entergy Btosciences program, earlier termed the Biological Energy Research program, was initiated in 1979 for the purpose of futfilling the need of basic information about plants and microorganisms refating to varied energy matters. The program generates basic information that contributes significantly to fubure technologies involving alternate fuel generation, petroleum replacennents, sustained industrial activities along with means of improving environmental conditions.

From its inception, the program has covered basic research in the areas of plant and gon-medical microbial science including physiology, biochemistry, genetios and other disciplinary approaches in order to gain a better understanding of how orgmisms finction and how they are structured. Topics such as photosynthesis, fementation, adaptation to natural stress conditions, ion uptake, nitrogen fixation, plant-microbe interactions, genetic regulation, metabolic pathways, transport activities and a myriad of other areas bive been included in the investigations sponsored. Some of the plants and microorganisms being studied, unlike certain other species, have not received a great amount of research attention, despite the critical role that such organisms have in nature. In order to achieve the establishment of new bictechuologies, the addition of information emerging from such studies is essential.

As the understanding of biological processes inereases, it is becoming clearer that firther comprenension will require broader approaches, including multidisciplinary investigations. The fact that the Energy Biosciences program is situated in the Office of Basic Energy Sciences with disciplines including chemistry, materials science, engineering, geosciences and others, facilitates interactions with these other disciplines. Such interactions between programs and scientific disciplines is of growing importance. The Energy Biosciences program has been ective in encotraging such interactions.

Energy Biosciences finds research in about 15 areas, and include the following: photosynthesis; plant cell wall development; plant respiration/nutrition/ion transport; plant and plant pigment metabolism; plant growth and developinent; plant gemetic regulation and genetic mechanisms; plant streas; plantpathogen/viral interactions; nitrogen fixation and plant-microbial symbiosis; ligmin-polysaccharide breakdown; fermentation microbial metabolism; one and two carbon microbial metabolism; extrenophilic microbes; microbial respiration, nutrition and metal metabolism; and materials biosynthesis. Over 200 projects were funded in FY 94 . Sample project titles and participants include:

- Anastobic Metabolism of Aromatic Compounds by Phototrophic Bacteria: Biochemical Aspects (Comell University) 
- Conversion of Acefic Acid to Methane by Thermophiles (Comel] University)

- Gene-enzyme Relationships of Aromatic Amino Acid Biosynthesis in Higher Plants (University of Florida)

- The Metabolism of Hydrogen by Extremely Thermophilic Bacteria (University of Georgia)

- Microbiology and Biochemistry and Anaerobic Fermentations: The Conversion of Complex Organjc Materials to Simple Gases (University of Georgia)

- Molecular Biology of Anaerobic Aromatic Biodegradation (University of Iowa)

- A National Cooperative for Genetic Engineering of Plant Lipids (Michigan State University)

- Genetics of the Sulfate-Reducing Bacteria (University of Missouri)

- Biosynthesis of Hydrocarbons (Ohio State University)

Amount of fonding avallable for chemicat industry-related $R \& D$ :

The FY 94 budget for Energy Biosciences activities was noughly $\$ 25$ million.

Length of invohement in chemical industry-retoted R\&D efforts:

The Biological Energy Research program was formed in 1979.

Relationship to OIT prograns ( $($ f applicable): None.

Notes:

Sources of information: Personal communication.

Amowal Report and Sumnaries of FY 1994 Activitiex, Division of Energy Biosciences (DOEJR-0621P).

Intemet resources.

Date of last revision: September 15, 1995. 


\author{
U.S. Department of Energy \\ Office of Energy Research \\ Office of Computational and Technology Research \\ Smal] Business Innoyation Research (SBIR) Office \\ ER-33 \\ 19901 Gerinantown Rd. \\ Germintown, MD 20874-1290
}

Contact: Dr. Samuel J. Barish, Program Manager

Phoue: $\quad 301-903-2917$

Fax: $\quad 301-903-6067$

E-mail: $\quad$ SAM.BARISH@MAILGW.ER.DOE.GOV

\title{
Descrtprion of agency tavolvement in chemical industry-related R\&D;
}

The Smalf Business Inmovation Research (SBIR) program is insndated by the Small Business Innovation Development Act of 1982 and the Small Business Restarch and Development Enhancement Act of 1992. Grant applications are solicited from small science- and technology-based U.S. fitms (with 500 employes or less). The program is designed form impleanentation in a thre-phase process, with Phase I detenmining, insofar as possible, the scientific or technical merit and feasibility of ideas proposed for investigation. The period of perfonnance in this initial phase is about six months and awards are currently liznited to $\$ 75,000$. Phase $\Pi$ is the principal research or $R \& D$ effort, and awants are now at a maximum of $\$ 750,000$ for wotk to be performed in a period of up to two years. Under Phase III, commencial applications of the reseanch or R\&D are to be pursued by small businesses with non-federal capital or, alternatively, Phese 11 may involve follow-on non-SBIR federal contracts for products or processes desired by the federal government.

The SBIR office is also responsible for the DOE's Small Business Technology Transfer (STTR) program, now completing its second year, which was established as a three-year pilot program in compliance with the Small Business Research and Development Enhancement Act of 1992. The STTR program is similar to, but smaller than, the SBIR program, except that the R\&D is carried out by the small business in collaboration with a non-profit researcht institution (e.g., govemment laboratory or university) serving as a subcontractor. The maxituum Phase I awards are for $\$ 100,000$ for nine months, and Phase II awards are for $\$ 500,000$ for two years. The projects supported in both the SBIR and STTR programs represent high-risk research, but the patential benefits are high if the objectives are met.

Areas of chemical industry-related R\&D inchude, bet are not linited to, basic research in the chemical and material sciences; more efficient utitization of, and environmental control technology for, fossil energy resources; sensors for process montoring and control; fuel cells and photovoltaic systems; monitoring and remediation of contaminated media; superconductors; design and applications of novel materials; robotics and remote operations; and naclear fivel cycle processes.

The SBIR and STTR programs of the DOE are currently funding approximately 140 Phase I and Phase II projects in these areas. Representative project titles include:

- Low Cost Contamination-Tolerant Electrocetalysts for Low-Tempenture Fuel Cells

- A New Type of Acoustical Sensor for Chemical Measurennents 
- A Novel Approach to the Renoval of High Concentrations of Nitrate and Nitride from Aqueous Waste Streams

- A Mid-Infrared Laser for Remote Sensing of Chemicals

- Pulsed Flow Adsorption Columns for Multi-Component Gas Separation

- Advanced Hot Gas Filter Development

- Advanced Ceranic Fibers for a Carbonate Fuel Cell Matrix

- Production of Carbon Materials for Lignin

- Composite Plasma-Polymer Membranes

- Fulkerene-Based Catalysis for Heavy Oi] Upgrading

- Economical Pbotochromic Fibers Based on Metal Oxides

- An Advanced Electrochemical Sensor for the Simultaneous Analytical Measurement of Three Chemional Species

Amount of fwuting available for chemicol indartry-related R\&D;

In FY 94, approximately \$22 million was awarded for SBIR and STTR chemical industry-related Phase

I and Phase II projects, and in FY 95, approximately $\$ 28$ million was awarded.

Length of invohenant in chemical industry-related RED effors:

The SBIR program was mandated in 1982, and the STTR program was mandated in 1992.

Relationship to OTT prograses (ff applicable):

Annual solicjtations are issued for both the SBIR and STTR programs, specifying the technical areas in which grant appitications are requested. From time to time, one of these areas comes within the responsibility of the Office of Industrial Technologies; a staff member of OIT serves as Technical Topic Manager for that areas, and is izvolved in the technical review and ovaluation of those grant applications.

Notes:

Sources of information: Personal communication.

Date of last reviston: August 1, 1995. 
U.S. Department of Energy

Office of Energy Research

Office of Health and Environmental Research, ER-70

19901 Gemnantown Road

Germintown, MD 20874-1290

Contact: Dr. Ari Patrinos

Phone: 301-903-3251

Fax: $\quad 301-903-5051$

Email: $\quad$ ARI.PATRINOS@OER.DOE.GOV

Description of agency involventent in chemical industry-related RaD;

Within the Office of Health and Environmental Research, the Biological and Environmental Research Program obtains scientific and technical knowledge in several directed research programs - that new knowledge should assist in the following: anderstanding and mitigating the long-tem health and environmental consequences from energy production and the use of different technologies; achieving fundamental understanding of biological and environmental components and processes; developing advanced technologies that will improve medical care, public health, and worker safety; adding value to the U.S. economy by enabling others to safely implement new or improved technologies; enabling other offices of DOE to succeed in their missions; and fostering a safe and appropriate use of science and rechnology to problems of national need.

Research divisions inchude: Environmental Sciences, Health Effects and Life Sciences Research, and Medical Applications and Biophysical Research. The office sponsors approximately 850 projects at the national laboratories and in the private sector.

Health reserarch topics include:

- Radiation and Chemical Effects

- Biological Effects Studies

- Cellular and Molecular Biology

- Physical and Chemical Processes

- Instrumentation Research

- Biotechnology

- Human Gemome

- Structural Biology

- Medical Applications

Environmental reserarch topics include:

- Environmental Processes

- Atmospheric Chemistry and Dynarnics

- Ocean Margins

- Subsurface Science

- Ecological Research

- Global Change

- Climate Modeling and Computer Hardware, Advanced Mathernatics, and Model Physics

- The Atmospheric Radiation Measturement Program 
- Carbon Cycle and Vegetation Research

- Oceans Research

- National Instiute of Global Environmental Change

Amount of funding awallable for chemlcat industry-related RAD:

For the Office of Environmental Health and Research, in FY 92, approximately $\mathbf{3 5 2}$ million was appropriated; in FY 93, approximately $\$ 343$ million was appropriated; in FY 94 approximately $\$ 388$ million was appropriated; and in FY 95, approximately \$426 was appropriated.

Length of imohement in chemicol industry-retated R\&D effors:

The Office of Environmental Health and Research traces its origins to the Atomic Energy Act of 1946, which pnovided the initial chanter for a comprehensive program of applied and basic biological and environmental research.

Retationshtp to OIT prograns (ff applicable): None.

Notes:

Sources of information: Personal communication.

Research in Progress: FY 1992, Summaries of Profects Sponsored by the Ofice of Health and Environmental Research (DOE/ER/0592). Internet resources.

Date of last reviston: September 8, 1995. 


\author{
U.S. Department of Energy \\ Office of Environmental Remediation and Waste Management \\ Office of Technology Development \\ 2400 Century Boulevard \\ Germantown, Maryland 20874 \\ Contact: Mr. Stephen Lien \\ Phone: 301-903-791 1 \\ Fax: $\quad 301-9003-7457$ \\ E-mail: STEPHEN.LIEN@EM.DOE.GOV
}

Description of agency iswotvement in chemical industop-related R\&D;

Within the Office of Environmental Remediation and Waste Management, the Office of Technology Development is responsible for managing an aggressive national program of applied research, development, demonstration, testing, and evaluation for environmental cleanup, waste management and related technologies. The techmology development program is designed to resolve major technical issues, to rapidly advance beyond curvent technologies for environmental restoration and waste managennest operations, and to expedite compliance with applicable environmental laws and regulations. The underlying strategy is to identify and develop high-payoff environmental restoration and waste maragement technologies that cani clean up the 1989 imventory of DOE nuclear component manufacturing sites; and manage DOE-generated waste faster, better, safer and cheaper than is possible with current environmental cleanup technologies. In many cases, the development of new technology presents the best hope for ensuring a substantive reduction in rist to the environment and iraproved worker/public safesy within realistic financial constraints.

The Office of Research and Development is responsible for the development of applied research and development programs at DOE sites nationwide. Programs are designed to identify operational needs in the areas of environmental restoration, waste operations, and corrective activities to rapidly advance beyond currently available technologies, and to provide solutions to key technical issues that, if not solved in a timely mannet, will adversely affect DOE's ability to meet its 30-year cleanup goat.

Amount of funding awailable for chemical industry-related RAD;

In FY 92, approximately \$169 million was alocated for research, development, demonstration, testing and evaluation. In FY 93, approximately $\$ 200$ million was allocated.

Length of inwolvenent in chenical industry-related R\&b efforts:

The Environmental Remediation and Waste Masagernent office was formed in 1989.

Retationshtp to OTT programs (ff appllcable): None.

Notex:

Sources of infornation: Personal communication.

Intenet resources.

Date of last revision: September 28, 1995. 
U.S. Department of Energy

Office of Fossil Energy, FE-231

20300 Century Boulevard

Germantown, MD 20874

Contact: Mr. Edward Schmetz

Phone: $\quad 301+903-3931$

Fax: $\quad 301-903-2406$

E-mail: $\quad$ EDWARD.SCHMETZ@HQ.DOE.GOV

Description of agency invotwement in chewicol indastry-related RdD:

The Office of Fossil Enerty manages a national technology program to increase natural gas and petroleum supplies and provide cleaner, more efficient ways to use coal and natural gas to generate electricity. The office also overses the Strategic Petrokem Reserve (the Nation's emergency oil stockpile) and the Naval Petroleun and Oil Shale Reserves. The office supports two technology enters which focus on fossil energy research: the Morgantown Energy Technology Center (METC) and the Piasburgh Energy Techuology Center (PETC).

The office has a program area known as elean fuels, where coal and natural gas can serve as the feedstocks for processes that produce clean liquid facls and chemicals that can substitute for petroleumbased liquids. The office is conducting thite major research prograns to develop more affordable and efficient techniques to produce these future sources of clean, supplemental fuels:

- Coal Liquefaction Technology - Converting Coal into Liquid Fuel

- Gas-to-Liquid Technology - Converting Methane and Light Hydrocarbon Gases to Liquids

- Coal-Based Alternative Fuels

Amount of funding avallable for chemical industry-related R\&D;

The clean fivels program area received approximately $\$ 25$ million in funding for FY 94 and $\$ 27$ million in FY 95.

Length of involvement in chemicol Industins-related RaD efforts:

The office has been involved in related effort's since the 1970's.

Relationship to OTT prograns (ff applicable):

Joint activities exist between Fossil Energy and OIT, particularly in the area of petroleum refining-

Notes:

Sources of information: Personal communication. Internet resources.

Date of last revision: September 20, 1995 . 
The following entries are DOE laboratories and facilities. These laboratories and facilities are heavily involved in chemical indastry-related efforts. However, most of this activity is besed on other DOE involvement, and the focus of this edition was intended to be on "headquarters" activities. A funure edition may contain more information about these laboratories and facilities.

Ames Labaratory

Ames, IA 50011

Argone National Laboratory

Argonne, IL 60439

Brookhaven National Iaboratory

Upton, NY 11973

Idaho National Engineering Laboratory

Idaho Falk, ID 83415

Kansas City Plant

Kansas City, MO 64141

Lawrence Berkeley Laboratory

Berkeley, CA 94720

Lawrence Livermore National Laboratory

Livermone, CA 94550

Los Alamos National Laboratory

Los Alamos, NM 87545

Morgantown Energy Technology Center Morgantown, WV 26507
National Institute for Petroleam and Energy Research Bartlesville, OK 74005

National Renewabie Energy Laboratcry

Golden, Co 80401

Oak Ridge National Laboratory

Oak Ridge, TN 37831

Pacific Northwest Laboratory

Richland, WA 99352

Pittsburgh Energy Technology Center

Pittsburgh, PA 15236

Sandia Nationsl Laboratories - Albuquerque

Albuquerique, NM 87185

Sandia National Laboratories - Livernore

Livermore, CA 94551

Savannah River Site

Aiken, SC 29801

$Y-12$

Oak Ridge, TN 37831 


\section{DEPARTMENT \\ OF \\ HEALTH AND HUMAN SERVICES}

The Department of Health and Human Services is the Cabinet-level department of the Federal executive branch most concerned with people and most involved with the Nation's human concerns. In one way or another - whether it is mailing out social security checks or making bealth services more widely available - Health and Human Services touches the lives of more Americans than any other Federal agency. It is literally a departuent of people serving people, from newborn babies to our most elderly citizens. 
U.S. Department of Health and Human Services

Public Health Service

Agency for Toxic Substances and Disease Registry (ATSDR)

Division of Toxicology

1600 Clifton Rd. NE, Mail \$top E-29

Atlante, GA 30333

Contact Dr. William Cibulas

Phone: 404-639-6306

Fax: 404-639-6315

E-mail: WTC1@ATSOD3.CDC.GOV

\section{Description of agency inwolnement in chemicat industro-related R\&D;}

Congress requires the Agency for Toxic Substmonces and Disease Registry (ATSDR) to implement the health-related sections of laws that protect the public from hasantous wastes and environmental spills of hazardous substances. Under the Comprehensive Environmental Response, Compensation, and Liability Act of 1980, as amended by the Superfund Anvendments and Reauthorization Act of 1986, ATSDR has, among others, responsibilities to: (1) conduct survey and sereening programs to detemine the relationships between exposure to toxic substances and illness; (2) conduct studies of pecple exposed to hazardous substances from a releace or threatened release; and (3) injitiate substancespecific research, in cooperation with the National Toxicology Program and Environmental Protection Agency, to determine the adverse health effects of exposure to hazandous substances. To meet its mandates, ATSDR works closely with state and federal agencies and the private sector. Toxicological research, including epidemiologic assessments of selected poptlations and toxicologic testing of individual chemicals or chemical mixtures, is currently conducted through contractual, interagency, and cooperative agreements. ATSDR is currently funding approximately 30 projects in these areas. Sample project titles and participants include:

- Prechronic Toxicity Studies on 1,1,1-trichloroethane (National Toxicology Program)

- Multi-generational Studies of the Toxic Effects of Mercury and Zine in Rats and Mice (Tuskegee University School of Veterinary Medicine)

- A Controlled Evaluation of Neurobehavioral Pefformance in a Cohort of Chronically Pesticide Exposed Farm Residents (University of Washington)

Amoukt of funding ovaliable for chemical industrp-related RED:

For research related to chemical toxicology, in FY 94, approximately $\$ 10$ million was obligated, and in FY 95 approximately $\$ 7$ million was obligated.

Length of involvement in chemical industry-related R\&D efforts:

ATSDR has provided extramural funds for related activities since approximately 1983.

Relationshtp to OIT programs (ff applicable): None.

Noles:

Sources of information: Personal communication.

Date of last revision: August 1, 1995. 
U.S. Department of Health and Human Services

Public Health Service

Centers for Disease Control and Prevention

National Center for Environmental Health

1600 Clifton Rd, NE, 1103 CMB-17

Atlanta, GA 30333

Contact: Dr. Eric Sampson, Director Environmental Health Laboratory Sciences

Phone: 770-488-7950

Fax: $\quad 770-488-4839$

E-mai]: Unknown

Description of agency imolvement in chemical industy-retated R\&D:

The mission of the National Center for Eavironmental Health is to promote health and quality of life by preventing and controlling disease, injury, and disability cansed by or related to the interactions between people and their environment outside the workplace.

The environmental health labotatory sciences component of the center encompasses advanced laboratory science to help prevent environmental disease; development and application of laboratory measurements of exposure to toxicants and health effects from exposures (e.g., cancer); laboratory assessment of exposure and disease for health studies of populations exposed or potentially exposed to toxicants such as lead, cadmium, mercury, dioxin, PCEs, pesticides, environmental tobacco smoke, benzene, toluene, and cthers; labonitory support during national and international environmental health energencies in order to determine the canse of death or disease; technical assistance, training, and technology transfer to states; central laboratory for the National Health and Nutrition Examination Survey; special prevention programs: infant screening for preventable diseases (e.g., sickle cell disease) and standardization of cholesterol measurements to diagnose and theat risk for coronary disease.

Branches inchude: clinical biochemistry, molecular biology, nutritional biochemistry, and toxicology.

Amount of funding avallable for chemeal industry-related R\&D:

In both FY 94 and FY 95, the amount of direet fiunding was approximately $\$ 6$ million annually.

Length of inowivenent in chemical industry-retated R\&D efforts:

The center (originally known as the Center for Environmental Health) was formed in 1980.

Relationship to orr progrems (f applicable): None.

Notes:

Sources of information: Personal commumication. Internet reschuces.

Date of last revision: September 11, 1995. 
U.S. Department of Heajth and Human Resources

Public Health Service

Centers for Disease Control and Prevention

National Institute for Oceupational Safety and Health

1600 Clifton Rd. NE

Mail Stop D30

Atlanta, GA 30333

Contact: Dr. Roy Fleming

Phone: $\quad$ 404-639-3342

Fax: $\quad 404-639-2196$

E-mail: Unknown

\section{Description of agency thwolvement in chemical industry-reloted RAD:}

The National Institute for Occupational Safety and Health (NIOSH) is a Federal agency that is part of the Centers for Disease Control and Prevention (CDC) and is responsible for conducting research and making recommendations for the prevention of work-related illness and injuries. The Institute's responsibilities include the following:

- Investigating potentially hazardons working conditions as requested by employers or employees

- Evaluating hazards in the workplace, ranging from chemicals to machinery

- Creating and disserainating methods for preventing disease, injury, and disability

- Conducting research and providing scientifically valid recommenditions for protecting workers

Amoust of farding aweilable for chemical industryarelated R\&D; Unknown.

Length of involvement in chemical industry-reloted R\&D eforts:

NOSH was established in 1970 as part of the Occupational Safety and Health Act of 1970.

Relattonship to OIT prograns (fi applicable): None.

Notes:

Sources of information: Personal cornmunication. Interuet resources.

Date of last rewiston: September 27, 1995. 
U.S. Department of Health and Human Services

Public Health Service

Food and Dng Administration

Cents for Drug Evalustion and Research

Office of Research Resources

Parklawn Building, 13B16

5600 Fishers Lane

Rockvilie, MD 20857

Contact Mr. Joseph Contrera or Mr. Frederic Geissel

Phone: $\quad 301-443-4750$

Fax: $\quad 301-443-4518$

E-mail: Unknown

Description of agency invotrement in chemical industry-related R\&D:

The Center for Drug Evaluation and Research is the Food and Drug Administration (FDA) arm that regulates prescription and over-the-counter medicines for humans. The center's mission is to:

- approve drugs for marketing that are effective for their labeled indications, provide benefits that outweigh their risks, are of high quality, and have directions for use that are complete and honestly communicated;

- facilitate eaty access to promising experimental drugs being developed for serious ilinesses with no adequate therapy;

- promote innovation and provide scientific leadership in the drug development process;

- ensure that the safety and rights of patients in drug sudies are adequately protected; and

- ensure that the quality and safety of medicines are maintained after marketing.

The center's efforts are coordinated with the National Center for Toxicological Research (see separate entry).

Amosnt of fanding awaitable for chemical industry-related R\&D: Unknown.

Length of invotwement is chemical indastry-related R\&D eforts:

The Food and Drug Administration has been involved in related efforts since its inception in 1907.

Relationship to OrT prograns (f applicable): None.

Nores:

Soures of information: Personal comnunication.

Intenet resaurces.

Date of lext revision: September 20, 1995. 
U.S. Department of Health and Human Services

Public Health Service, Food and Drug Administration

National Center for Toxicological Research

3900 NCTR Road .

Jefferson, AR 72079-9502

Contact $\quad$ Mr. Pete Attwood, Associate Director for Research Support

Phone: $\quad$ 501-543-7504

Fax: $\quad 501-543.7576$

E-mail $\quad$ VATTWOOD@FDANT.NCTR.FDA.GOV

\section{Description of asency thwohement in chemical industy-related R\&D:}

The National Center for Toxicological Research (NCTR) is a Food and Drug Administration (FDA) research facility whose mission is to conduct peer-reviewed scientific research that supponts and anticipates FDA's current and future regulatory needs. This involves fundamental and applied research specifically designed to define biological mechanisus of action undertying the toxicity of products regulated by the FDA; aimed at understanding critical biological events in the expression of toxicity and at developing methods to improve assessment of human exposure, susceptibility and risk.

Programs include:

- Analytical Methods Developinent - Transgenics

- Applied and Environmental Microbiology - Solid-State Toxicity

- Biochenical and Molecular Markers of Cancer - Neurotoxicology

- Developmental Toxicology - Quantitative Risk Assessment

- Nutritional Modulation of Risk and Toxicity

Sample project titles include:

- Degradation of Polycyclic Aromatic Hydrocarbon by Bacteria in Continuous Culnure

- Multinuclear NMR Studies on the Strueture and Conformation of Metabolites and Adduets of Polycyclic Aromatic Hydrocarbons

- Toxic Hazards foom Anti-Thyroid Chemicals

- Mechanișps of Drug Toxicity

Amount of funding awillable for chenical industry-related RAD:

The center's total budget for FY 95 was approximately $\$ 42$ million.

Lenght of inwolvement is chemical indaston-ralated R\&D effortst

The center was established in 1971 .

Relationshlp to OrT programs (if applleable): None.

Notes:

Soures of information: Personal comumunication.

NCTR Research Accomplishments and Plows, FY 1994.95.

Date of last revision: September 12, 1995. 
U.S. Department of Health and Human Services

Public Health Service, National Instiutes of Health

National Institute of Environmental Health Sciences

National Toxicology Program

P.O. Box 12233

Research Triangle Park, NC 27709

Contact: $\quad$ Dr. Kenneth Olden, Director

Phone: $\quad 919-541-3201$

Fax; $\quad 919-541-2260$

Email: Unknown

Description of agency invofvemest in chemical industo-related R\&D:

The National Toxicology Program (NTP), headquartered at the National Instinte of Envinonmental Health Sciences (NIEHS) in Research Triangle Park, NC, was established as a cooperative effort within the Public Health Service to coordinate toxicology research and testing activities within the Department of Health and Human Services, to provide information about potentially toxic chennicals to health, regulatory, and research agencies and the public, and to strengthen the science base in toxicology.

The three NTP participating agencies are the NIEHS, the Food and Drug Adninistration's National Center for Toxicological Research, aud the Centers for Disease Control's National Institute for Occupational Safety and Health. Progran areas include the following:

- Cancinogenesis

- General Toxicology

- Immunotoxicology

- Neurotoxicoloty

- Respiratory Toxicology

- Reproductive and Developmental Toxicology

- Cbemical Disposition

- Altemative Methods.

Amount of funding available for chemical industry-retated R\&D;

The National Toxicology Ptogram receives funding from the participating agencies with the vast majority coming from NIEHS. In FY 94, tofal funding was approximately $\$ 82$ million.

Length of thvolvenent in chemicul industry-reloted R\&D efforts:

The National Toxicology Program whs established is 1978.

Relationship to OTT progroms (of applicable): None.

Notes:

Sourses of information: Personal communication. Notional Toxicology Progrom Fiscal Year 1994 Anntual Plan. Intermet resources.

Dote of last revirion: September 8, 1995. 
U.S. Department of Health and Human Services

Public Health Service, National Institutes of Health

National Institute of Environmental Health Sciences

Superfind Basic Research Program

P.O. Box 12233

Research Triangle Park, NC 27709

Contact: Ms. Beth Anderson, Program Analyst

Phone: $\quad$ 919-541-4481

Fac: $\quad$ 919-541-2843

E-mait: TAINER@NIEHS.NIH.GOV

Description of agency mwolvement in chemical industry-related ReD:

The Superfund Basic Research Program (SBRP) is a university-based program focusing on basic research and training grants directed towards understanding, assessing, and attenuating the adverse effects on human health resulting from exposure to hazardous substances. Grants made under the SBRP are for coordinated, multicomponent, interdisciplimary programs; the objective is to establits and maintain a unique Program linking biomedical research with related engineering hydrogeologic, and ecologic components. The progran was enated by the Superfund Amendments and Reauthorization Act (SARA) of 1986 to complentent existing activities within the EPA and ATSDR.

The SBRP is intended to support a wide range of research to address the broad public health concenns arising from release of hazarilous substances and hazardous wastes imto the environment; particularly from uncontrolled, leaking waste disposal sites. The ultimate goal of the program is to prevent adverse human health effects. Presently, the program funds 17 grants encompassing approximately 140 individual research projects, and include the following mandated areas:

- Methods and technologies to detect hazandous substances in the envinoninent

- Advariced techniques for the detection, assessment, and evaluation of the effects on human health of hazardous substances

- Methods to assess the risks to human health presented by hazardous substances

- Basic biological, chemical, and physical methods to reduce the amount and toxicity of hezardous substances.

Amount of funding anailable for chenulcal industry-nelated R\&D:

Avthorized funding for the program in both FY 94 and FY 95 was around $\$ 35$ mitlion for each year.

Length of inwohoment in chenical thatwog-related R\&D efforts:

The program has existed since 1987.

Relationship to OTT progrens (if applicablej; None.

Notes:

Sources of information: Persongl communication.

Internet Resources.

Date of last revistion: August 28, 1995. 
U.S. Department of Health and Hunan Services

Public Health Service, National Institutes of Health

National Institute of General Medical Scieaces

Natcher Bldg., Room 2AN-12

45 Center Dive MSC 6200

Bethesdi, MD 20892-6200

Contact: $\quad$ Mr, Marvin Cassman, Acting Director

Phone: $\quad 301.594-2172$

Fax: $\quad 301-402-0156$

E-mail: $\quad$ CASSMANM@GM1.NIGMS.NIH.GOV

Description of agency twolvement in chentical industra-related R\&D;

The National Institute of General Medical Sciences (NIGMS) is one of the National Institutes of Health (NIH), the principal biomedical research agency of the federal govermment. NIGMS is unique among the components of NIH in that its main mission is the advancement of the basic biomedical sciences. NIGMS supports selected research and research training programs (not tringeted to specific diseases or disorders) in areas that underlie all medical investigation, such as pharmacology and biorelated chemistry, and cellular and molecular biology. Knowledge resulting from this work contributes directly to the progress of research on specific diseases in the other components of NIH. NIGMS also develops and supports interdisciplinary studies in genetics, biophysics, physiology, and trauma and burn research.

Because scientific breakthroughs often originate from such untargeted studies, NIGMS-funded work has contributed substantially to the tremendous progress that biomedical research has made in recent yeers. The lnstinte's training programs help provide the most critical element of good research: well-prepared scientists. NIGMS has three divisions that support research and research training in basic biomedical science fields. The vast majority of this money goes to fund grants to scientists at universities, medical schools, bospitals, and research institutions throughout the conntry. At any given time, NIGMS supports over 3,300 research grants-abbout 14 percent of the grants funded by NIH as a whole. The key areas in which these divisions find research are listed below their names:

Division of Cell Biology and Biophysics

- analyticil and separation techniques

- biomedical instrumentation

- lipid biochentistry

- molecular biophysics

- structural biology

- bioenginesing

- cell organization, motility, and division

- membrane structure and function

- spectroscopic techniques

Division of Genetics and Developmental Biology

- cell growth and differentiation

- control of gene expression

- extrachromosomal inheritance

- mechanisms of mutagenesis

- neurogenetics and the genetics of behavior

- replication, recombination, and repair of genes

- chromosome organization and mechanics

- developmental geneties and cell biology

- human medical genetics

- molecular immunobiołogy

- population genetics 
Division of Pharmacology, Physiology, and Biological Chentistry

- anesthesiology

- biosnergetics

- biotechnology

- medicinal chemistry

- physiology

- trauma and burn injury

- biochemistry

- bio-organic and bio-inorganic chemistry

- glycoconjughates

- pharmacology

- synthetic chemistry

Anownt of funding andiable for chemlcal industry-related $R \& D$ :

In FY 1995, the institute's budget was $\$ 905$ million. The breakdown for the thre major divisions is as follows:

- Genetics and Developmental Biology

$\$ 277.2$ million

- Pharmacology, Physiology, and Biological Chemistry \$260.3 million

- Cell Biology and Biophysics $\$ 281.4$ million.

Length of involvenent in chemical industro-reloted ReD efforts: NIGMS was established in 1962.

Relationshtp to OIT programs (ff applionbley: None.

Notes:

Sources of information: Internet Resourcess.

Division contacts:

Cell Biology and Biophysios:

Dr. James C. Cessatt, Director 301-496-7253

CZJ@CU.NIH.GOV

Genetics and Developmental Biology :

Dr. Judith H. Greenberg, Dirextor 301-594-0943

GREENBEJ@GM1.NIGMS.NIH.GOV

Pharmacology, Physiology, and Biological Chemistry :

Dr. Michatel E. Rogers, Acting Director 301-594-3827

ROGERSM@GMI.NIGMS.NIH.GOV

Dafe of last ravision: August 29, 1995. 
U.S. Department of Health and Human Services

Public Health Service

SBIR/STTR Solicitation Office

13687 Baltimore Avenue

Lanirel, MD 20707-5096

Contact $\quad$ SBIR/STTR Solicitation Office

Phone: (301) 206-9385

Fax: $\quad$ (301) 206-9722

Internet: a2y@cu.nih.gov

Description of agetcy inwolvanent in chemical industry-related R\&D:

The Public Health Service Small Business Imnovation Research (SBIR) Program encourages proposals in fietds of interest to the service. Phase I awerds may not exceed \$100,000 for dinect costs, indirect costs, and fixed fee for a period nomally not to exceed six months. Phase II awands may not exceed $\$ 750,000$ for direct costs, indirect costs, and fixed fee for a period normally not to exceed two years. Around 700 Phase I awards are expected to be made based on the most recent solicitation.

Sample topic areas with relevance to the chemical industry inclwde:

- Pharmaceutical Development for Alcoholism Treatment

- Effects of Drugs at the Cellular Level

- Toxicity Stodies

- Pharmacology, Physiology, and Biological Chemistry Division (NIGMS)

- Enginearing Control Systems

In FY 94, 746 awards were made, 596 for Phase I and 150 for Phase II. Sample awards include:

- Novel Biopolymers for the Medical Industry

- Dehydrogenase Crystals as Catalysts in Organic Synthesis

- Improved Ultrafilters for Bioprocessing

- Novel Fluorogenic Enryme Substrates and Their Uses

Amount of funding avollable for chemical indactry-reloted R\&D:

In FY 94, funding for awards totaled over $\$ 133$ million.

Length of involvemem in chenical indastry-related R\&D effors:

The Public Health Service SBIR program has existed since the early 1980s.

Relationship to OrT prograns (ff applicable): None.

Notes:

Sources of tinformation: Personal communication.

Small Business Innowation Research Fiscal Year Phase I and Phase II Projects Abstract Book, FY 1994, Dept of Health and Human Services. Internct Resources.

Dafe of lost revtsion: September 29, 1995. 



\section{DEPARTMENT OF THE INTERIOR}

As the Nation's principal conservation agency, the Department of the Interior has responsibility for most of our nationally owned public lands and natural resources. This includes fostering sound use of our land and water resources; assessing and protecting our fish, wildife, and biologicaj diversity; preserving the environmental and cultural values of our national parks and historical places; and providing for the enjoyment of lifo through outdoor recreation. The Departsnent assesses our mineral resources and works to ensure that their development is in the best interests of all our people by encoutaging stewardship and citizen participation in their care. The Department also has a major responsibility for American Indian reservation communities and for people who live in island territories under U.S. administration. 
U.S. Department of the Interior

Burean of Mines

Center for Materials Partmerships

Albany Research Center

1450 Queen Avenue SW

Albany, OR 97321-0021

Contact Mr. Bill Riley

Phone: 503-967-585I

Fax: $\quad 503-967-5936$

E-mail: RILEY@ALRC,LSBM,GOV

Description of agency inwolvenent in chenaical industry-related R\&D:

The Center for Materials Partnerships, through partnerships with industry, government and acactemia, develops new technologies that conserve resources through extending service life and reduce environmental impact by substituting materials or new processes.

Primary areas of chemical industry-related R\&D emphasize materials for harsh environments. The Center for Materials Partnerships is currently funding approximately eleven projects in these areas. Sample project titles include:

- Continuous Production of Titanium Powder

- Processing and Properties of Advanced Refractory Ceramics

- Wear-Conosion Mechanisms in Mineral Processing

Amount of funding avallable for chemical iadustpr-related R\&D:

In FY 94, approximately $\$ 4.8$ million was authorized, and in FY 95, approxirnately $\$ 4.4$ million was authorized.

Length of involvenent in chemical industry-related R\&D efforts:

The Center for Materials Pertnerships was formed in 1995. Prior to this date, the materials research was conducted within the Division of Minerals and Materials Science.

Relationstip to orr programs (ff applicable): None.

Notes:

Sources of information: Personal communication.

Other contact: Pragna Bhakta, 202-501-9284.

Date of last rewhlon: August 2, 1995. 
U.S. Department of the Interior

Bureau of Mints

Center for Pollution Prevention and Control

Salt Lake City Research Center

729 Arapeen Drive

Salt Lake City, UT 84108-1283

Contact Ms. Paulette Lym

Phone: 801-584-4152

Fax: $\quad 801-584-4134$

E-mail; $\quad$ LYMPB@SLRC.USBM.GOV

Description of agency inwolvenent is chentical industryntelated R\&D:

The Center for Pollation Prevention and Control develops and demonstrates cost-effective technologies to prevent enviromiental damage from mining and mineral-related activities, in partnership with other government agencies, producers and consumers.

Prinary areas of ciremical industry-related R\&D emphasize environmentally compatible extraction systems, improved sensors and process control technology, bioprocessing, and toxichazardous waste disposal. The Center for Polhation Prevention and Control is currently funding approximately ten

- projects in these areas. Sample project titles and participants include:

- Rapid Analysis and Control of Process Streans (Kennecott Copper Company)

- Thiosulfate As an Alternative to Cyanide (Electric Power Research Institute)

- Double Membrane Electolytic Cell Technology (BHP Minerals, HECLA)

- Fundamental and Applied Aspects of Mineral Bioprocesses (BHP Minerals, Copper Range Minjng Company)

Amoun of funding opallable for chemical indastrytrelated ReD;

The Center for Pollution Prevention and Control was newty formed in FY 95. Approximately \$21 million was authorized.

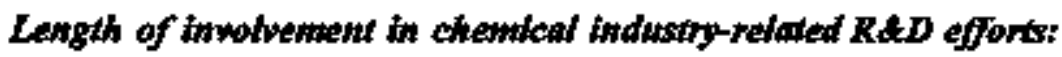

Prior to the fommation of the Center for Pollution Prevention and Control, this kind of work was conducted within the Division of Minerals end Materials Science.

Relationship to OTT prograns (ff applicable):

Joint project on appliance recycling and close cooperation in the recycling arena.

Notes:

Satures of information: Personal communication.

Other contact: Pragna Bhalkta, 202-501-9284.

Date of last rewtston: August 2, 1995. 
U.S. Department of the Interior

Bureau of Mines

Division of Environmental Technology

8107 th Streat

Washington, DC 20241

Contact: $\quad$ Mr. William Schrnidt

Phone: $\quad 202-501-9269$

Fax: $\quad 202-501-9957$

E-mail: Unkrown

Description of atency iswolvement in chemical indartry-related R\&D;

The Division of Environmental Technology, through parmerships with industry, government and academia, develops innovative technologites to remediate environmental contamination from the mining and mineral processing industries. The Division is currently funding two chemical industry-related research projects in this area:

- Trealment of Phosphate Wastes

- Vitrification of Municipal Wastes

Amount of funding awallable for chemical indwastrelated $R A D$;

In FY 94, approximately $\$ 440,000$ was authorized for these research efforts, and in FY 95 approximately $\$ 440,000$ was authorized.

Length of inwolvewent is chemical indurry-related R\&D effort:

The Division of Envinonmental Technology was formed in 1987 to develop innovative technologies to prevent and remediate environmental contamination associated with mining and minera" processing-

Relationship to OrT programs (ff appticable): None.

Noves:

Sources of information: Personal communication.

Date of last rewision: August 1, 1995. 


\section{DEPARTMENT \\ OF \\ TRANSPORTATION}

The U.S. Department of Transportation establisbes the Nation's overall transportation policy. Under its umbrella there ane nime administrations whose jurisdictions inchude highway planning. development, and construction; uban mass transit; railroads; aviation; and the safety of waterways, ports, highways, and oil and gas pipelines. Decisions made by the Department in conjunction with the appropriate state and local officials strongly affect other progtams such as land planning, energy conservation, scarce resource utilization, and technological change. 
U.S. Department of Transportation

Federal Highway Administration, Office of Research and Development

Office of Enginering and Highway Operations Reseanch and Development

6300 Old Georgetown Pike

MeLean, VA 22101

Contact: $\quad$ Mr. Brian Chollar

Phone: $\quad 703-285-2342$

Fan: $\quad 703-285-2950$

E-mail: Unknown

Description of agency inwolvenewt in chanicul indastry-related RAD:

The Federal Highway Administration administers highway transportation programs of the Department of Transportation. Research and technology programs focus on: intelligent vehicle/highway systems, highway R\&D, long-term pavement perfonmence, techinology applications, rural technical assistance, and the National Highway Institute. The administration focuses its programs on highway safety, structures, pavements, materials, environment, policy, and plarning to discover ways to improve the quality and durabitity of highway and streets, to reduce construction and maintenance costs, address energing highway policy issues, respond to planning and environmental requirements of the Intermodal Surface Transportation Efficiency Act, and analyze impacts of highway transportation.

Within the Turner-Fairtank Highway Research Center exists the Office of Reseanch and Development with around 20 separate taboratories. Research areas relevant to the chemical industry include:

- Asphatt research including asphalt modification and solventless recovery systems for recycling

- Corrosion research including solventless paints and coatings for bridges and re-bars

- Snow and ice control chemical research including calcium magnesium acetate and potassium acetate production (through low-cost acetic acid production methods) and anti-icing technology.

\section{Amount of funding avalable for chemicel industry-related $R \& D$ :}

In the past several years combined, around $\$ 11$ million has been spent for anti-icing techunology, snow and ice control, and calcium magnesium acetate research; $\$ 7$ million for corrosion research; and $\$ 6$ million for asphalt modification research.

Length of involvenent in chemical induspy-related RSD effors:

Most of these efforts have occurred in the past 10 years. The Federal Highway Administration has been studying asphalt properties for nearly 50 years.

\section{Relationshy to OT prograns (f applicable):}

No formal relationship, however, the OIT projects Development of Asphalts and Povements Using Recycled Tine Rubber, Development of Superior Asphalt Recycling Agents, and Biological Conversion of Waste Gases imto Aceric Acid are of interest to the administration.

Notes:

Sources of information: Personal communication.

Date of last revision: September 25, 1995. 


\section{ENVIRONMENTAL \\ PROTECTION \\ AGENCY}

The Environmental Protection Agency protects and enbances our environment today and for future generations to the fullest extent possible under the laws enacted by Congress. The Agency's mission is to control and abate pollution in the areas of air, water, solid waste, pesticides, radiation, and toxic substances. Its mandate is to mount an integrated, coordinated attack on environmental pollution in cooperation with state and local goveruments. 
U.S. Environmental Protection Agency

Innovative Technology Council

Environmental Technology Initiative

$401 \mathrm{M} \mathrm{St}$ SW

Washington, DC 20460

Contact Mr. Fred Lindsey

Phone: $\quad$ 202-260-2600

Fax: $\quad$ 202-260-3861

E-mail: $\quad$ LINDSEY.ALFRED@EPAMAIL.EPA.GOV

\section{Deseription of agency involvenent in chenical industry-related RQD:}

The Environmental Technology Initiative (ETI) was outlined by President Clinton in February 1993 as a means of accelerating environmental protection, strengthening America's industrial base, and increasing exports of U.S. technologies and expertise. The initiative intends to serve a catalytic role in promoting the development of new technologies across a range of industrial sectors, including semiconductors, transportation, emvironmental management, information technology, cleaner industrial technologies that prevent pollution, defense conversion, and others.

In FY 94, the initiative funded 78 projects. The primary FY 95 solicitation, which seeked proposals from federal agencies, states, and Indian tribes, included emphasis on certain industries and processes, which include:

Industrial Sectors: Special emphasis will be placed on industries dominated by small business as well as those being studied in the Agency's Common Sense Initiative, the Design for Environment Program and others. Potential industries include:

$\begin{array}{lll}\text { - metals } & - & \text { electronics } \\ \text { - dry cleaning } & * & \text { printing }\end{array}$

Unit Operations: Industrial manufactoring operations have several processes that are common to various facilities regardless of their purpose. The pollution prevention technologies topic area seeks innovative technology propossals for:

- cleaning and degreasing - coatings and solvents

- refrigerants used for cooling

Functional Areas: Operational methods through which pollution prevention can be achieved will also be considened. These methods include research on process chemistry and/or changes that reduce the production and use of hazardous chemicals. Candidate areas include:

- gren chemistry - process controls and feedback systerus

- green buildings

Amown of fonding avallable for chemical industry-related ReD:

The Congress appropriated \$36 million for EII in FY 94 and appropriated $\$ 68$ million in FY 95. The primary FY 95 solicitation provided $\$ 40$ million in funding. The E11 also funds other smaller solicitations and climate change projects. 
Length of involventent in chentcel indiatry-related R\&D effors:

The Environmenta! Technology Initiative was initiated in FY 94.

Relationthip to OTT programs (Of applicable):

OIT solicited proposals for projects for the Environmental Technology Initiative.

Notes:

Sources of information: Personal communication.

Pollttion Prewention Directory, EPA.

Internet resources.

Date of Jast rewiston: September 11, 1995. 
U.S. Environmental Protection Agency

Office of Prevention, Pesticides, and Toxic Sulstances

Design for the Enviroument Program

$401 \mathrm{M}$ St. SW (TS-779)

Washington, DC 20460

$\begin{array}{lll}\text { Contact } & \text { Mr. Paul Anastas } & \text { Dr. Joseph Breen } \\ \text { Phone: } & \text { 202-260-2659 } & 202-260-1678 \\ \text { Fax: } & \text { 202-260-0981 } & \text { Unknown } \\ \text { E-mail: } & \text { ANASTAS.PAULQEPAMAIL.EPA.GOV } & \text { Unkmown }\end{array}$

\section{Dexcription of agency involvement in chemical industry-related R\&D:}

The Design for the Environment (DfE) Program has been created to apply EPA's expertise and leadership to inform and facilitate pollution prevention efforts. It hanesses the expertise for which the Office of Pollution Prevention and Toxies is best known: comperative and multi-media risk analysis, methods for evaluating alternatives for risk reduction, knowledge of regulatory requirements, and outreach to industry and the public on pollution prevention topics. The DfE Program focuses on areas it is most faniliar with: pollution prevention efforts and environmental risk areas. Thus, the DfE Program promotes the incorporation of environmental considerations, and especially risk reduction, in the design and redesign of products and services. The Program works on a voluntary basis through partnerships with industry and the public formed to apply EPA expertise to specific issues.

One project within the program, Chemical Design, aims to change the way organic chemists approach the design of synthetic pathways for chemical production. EPA is encouraging consideration of alternative synthetic pathways through: (1) grant awards to academic institutions; (2) discussion at national symposir; and (3) ase of computer programs which assist in the design of chemical pathways. In 1992, EPA awarded six grants to find basic research projects which consider environmental impacts, and not just yield, in the design of chemical synthetic pathways. EPA has joined forces with the National Science Foundation (NSF) through a memorandum of understanding to award additional grants. By fostering this kind of besic research in organic chemistry, EPA and NSF hope to bring about a paradigm shift in the way chemists, in both academia and the chemical industry, think about the design and manufare of chemicals. Grant titles include:

- Altemative for Toxic Solvents

- New Synthesis of Styrene

Replaxing Benzene with Simple Sugars

Amount of funding available for chemical industry-related R\&D; Unknown.

Length of hoolvement in chemical industrg-related RAD efforts: Unknown.

Relationshtp to OT prognams (ff applicable): None.

Nates:

Sources of information: Personal communication.

Internet resources.

Date of last revision: September 28, 1995. 
U.S. Environmental Protection Agency

Office of Prevention, Pesticides and Toxic Substances

Office of Pollution Prevention

$401 \mathrm{M}$ St. SW

Washington, DC 20460

Contact: Ms. Lena Hann

Phone: 202-260-2237

Fax: Unknowi

E-mail: Unknown

\section{Description of agency buotvenent in chenical indastry-reloted R\&D;}

The Office of Pollution Prevention coordinates EPA policy development in pollution prevention in all sectors. The office's charge is to help integrate a multimedia pollution prevention ethic both inside and outside EPA. While this office is the focal point of EPA's overall pollution preverption program, its primary role is to support pollution prevention efforts by the EPA's program offices, EPA regional offices, state and local governments, industry, and the public. To help accomplish its goals, pollution prevention coonfingtors have been established in both EPA's program offices and regicans. The office funds a number of pollution prevention activities with relevence to the chemical industry, including:

National Intustrial Competitiveness though Energy. Envinonment, and Economics (NCE) Program: A grant program designed to improve industrial energy efficiency, reduce costs, and lower entissions to the envizonment through the demonstration of innovative technologies.

Pollution Prevention Incentives for States: A grant program intended to build and support state pollution prevention ceppabilities and to test, at the state level, innovative pollution prevention approaches and methodologies throngh demonstration projects.

Agriculture in Concert with the Environment: A joint grant program between EPA and the Department of Agriculture which promotes the adoption of sustainable agriculture practices and reduces the use of highly toxic herbicides and other pesticides.

Amount of fanding abotiable for chewical industry-related RdD: Unknown.

Lergth of iswotventent in chemical industry-related R\&D efforts: Unknown.

Relotionshit to OTT pogrous (ff applicuble):

The NICE ${ }^{3}$ Program is co-funded and manyiged by OIT.

Notes:

Sources of information: Persongl communication. Pollution Prevention Directory, EPA.

Contact for Agricultare in Concert with the Enviromment. Mr. Harry Wells, 703-308-8139.

Date of last revition: September 28, 1995. 
U.S. Environmental Protection Agency

Office of Research and Development

National Center for Extramusal Research and Qualty Assuzance

$401 \mathrm{M} \mathrm{St}$ SW (8701)

Washington, DC 20460

Contact Dr. Melinda MeClanahan, Associate Dinector for Science

Phone: $\quad 202-260-5750$

Fax: 202-260-0450

E-nail: $\quad$ MCCLANAHAN.MELINDA@EPAMAIL.EPA.GOV

\section{Description of atency involvement in chemical ind hotry-related RdD:}

The National Center for Extramural Research and Quality Assursance located in the Washington, D.C. area, is responsible for developing and managing on investigator-initiated research grants program. In addition, the center is also responsible for:

- Fellowships for undergraduate, graduate, and post-doctoral studies in seientific and engineering disciplines relevent to enviroamental stewardship;

- Mandatory quality assurance policy and oversight for all EPA programs isvolving environmental measurernents;

- Ageney-wide coordination of activities related to development, validation, and use of envirosmental monitoring methods;

- Peer reviews for the center's activities and for selected projects within other Office of Research and Development programs, EPA National and Regional Program Offices; and

- Visiting scientists and senior environmental employee programs.

The investigator-initiated nesearch grants program supports basic research on environmental issues. Applications for FY 94 research grants were based on a general solicitation for applications which focused on broad environmental fieids such as biology, chemistry, physics, engineering, and socioeconomics. Approximately 75 grants were awarded in FY 94. Sample project titles include:

- Influence of Organic Films on Reactivity and Hydroscopicity of Sulfuric Acid Aerosol

- Solventless Extraction of Organic Pollutants from Water with Solid-Base Microextraction

- Development of an Economic Treatenent System to Detoxify Organic Chernicals

- Configuration and Sorption Properties of Two Synthetic Hutnic Substance Analogs: Polymaleic Acid and Pyrene-Labeied Polyacrylic Acid

- Degadation of Alkyl Halides by Nitrifying Bacteria Associated with Soil

Amount of fanding available for chemical indutrymetated ReD:

The funding level for the research grants program was approximately $\$ 21$ million in FY 94 and $\$ 44$ million in FY 95.

Length of inwolvement in chemical industry-related RdD efforts:

The investigator-initiated research grants program has existed since 1980 .

Relotionship to OIT prograws (if applicable): None. 
Notes:

Sources of information: Personal communicution.

Annul Report of the Research Gromts Prognam I994, Office of Exploratory Reseanch (EPA 600-R-94-158).

Internet resources.

Dote of last revision: September 14, 1995. 
U.S. Environmental Protection Agency

Office of Research and Development

National Risk Management Research Laboratory

Air Polution Prevention and Control Division

Mail Drop 60

Research Triangle Park, NC 27711

Contact: Mr. Charlie Sedman

Phone: $\quad$ 919-541-77\%0

Fax: Unkrown

E-mail: $\quad$ Unkrown

Description of agency involvememt in chemical industry-related R\&D:

The Air Pollution Prevention and Control Division of the National Risk Management Research Laboratory is EPA's major research organization for research, development, and evaluation of air pollution control technologies. The Division is located in Rescarch Triangle Park, NC. The division has 8 branches and a staff of 102 researchers, technicians, and support staff. The Lab's branches are:

- Emissions and Modeling Branch

- Global Warming Control Branch

- Organics Control Branch

- Stratospheric Ozone Control Branch

- Combustion Research Brancb

- Gas Cleaning Teclmology Branch

- Indocr Air Branch

- Radon Mitigation Branch

Amount of funding awalloble for chemical industrja-related R\&D: Unknown.

Length of imwolvement in chemloal industy-related R\&D efforts: Unknown.

Relationship to OrT progrous (ff applicable): None.

Notes:

Soures of information: Personal communication. Internet resources.

Date of lasst revision: September 28, 1995. 


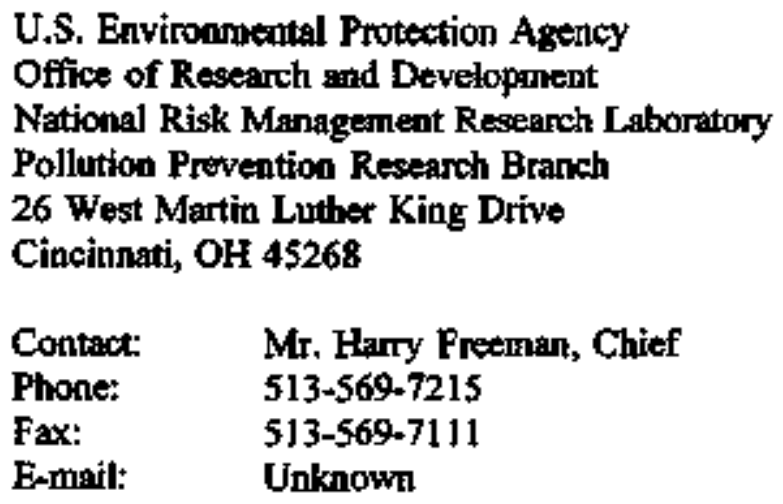

Description of agency involvement in chenticul industry-related R\&D;

The Pollution Prevention Rosearch Branch at the National Risk Management Research Laboratory (formerly the Risk Reduction Engineering Laboratory) is responsible for supporting projects that develop and demonstrate clean proctuction technologies, clean products, and insovative approaches to reducing the generation of pollutants in all media. The branch also supports pollution prevention assessments, lifecycle assessment and measurement methodologies, and promotes pollution prevention within the federal government. Many of the branch's efforts within each of five elements are carried out cooperatively with other government agencies, universities, and other envirommental research organizations.

Elements under Cleaner Production Technologies include:

- Waste Rechuction Innovative Technology Evahuation

- Support for RCRA Hard to Treat Wastes

- Support for the 33/50 Program

- Support for the Source Reduction Review Programt

- Clean Technology Design and Development Projects.

Elements under Cleaner Products Research inclade:

- Evaluating the Potential for Safe Substitutes

- Clean Products/Source Reduction Case Stadies

- Product and Process Design for Life-Cycle Risk Reduction

- Environmental Impact Mitigation.

Elements under Tools to Support Pollution Prevention include:

- Life Cyele Assessment Development and Demonstrations

- Measurement Methodology Tools Development.

Elements under Cooperative Pollution Prevention Projects with Other Federal Agencies include:

- Waste Reduction Evaluations at Federal Sites Program

- Stratogic Envitonmental Research and Development Program

- Integrated Design Research Program. 
Elements under Pollution Prevention Assessments and Support include:

- Small Generator Waste Mirimization Assessments

- Industrial Assessment Centers Program

- Pollution Prevention for Public Agencies

- NATO/CCMS Project: Pollution Prevention Strategies for Sustainable Development

- Clean Technologies Guide.

Sample project titles include:

- Methyl Ethyl Ketone Substitute in Aircraft Radome Depainting

- Lifo Cycle Assesement Demonstration: Carpeting

- Coating Technology for Wood, Plastics and Composites

- Sodium Chloride Substitute for Deicing

- Supercritical $\mathrm{CO}_{2}$ Flurid for Precision Parts Cleaning.

Amount of funding arallable for chemical industorelated R\&D:

The.FY 94 budget for the branch was approximately $\$ 3.5$ million.

Length of involvement in chemical industy-related RAD eforts:

The Pollution Prevention Resealch Branch was started in 1988.

Relationship to OIT prograns (ff applicable):

The OIT Energy Analysis and Diagnostic Centers program is being meged with the EPA Waste

Minimization Assessment Centers program to form the Industrial Assessment Centers program.

The bermch is also working with the OIT Alternative Feedstocks program in life cycle assessment research.

Notes:

Soutes of information: Personal communtcation.

Pollution Prevention Research Branch Current Projects, November 1994.

Date of inst revision: August 28, 1995. 


\author{
U.S. Environmental Protection Agency \\ Office of Research and Development \\ Small Business Imovation Research Program (8301) \\ $401 \mathrm{M}$ St. SW \\ Washington, DC 20460 \\ Contact: Mr. Don Carey \\ Phone: 202-260-7899 \\ Fax: 202-260-4524 \\ E-mail; $\quad$ CAREY.DON@EPAMAIL.EPA,GOV
}

\title{
Description of agency involvement in chemical indastry-related R\&D:
}

The EPA Small Business Innovation Research (SBIR) Program encourages proposals in advanced application arees in the fields of environmental engineering and environmental monitoring instrumentation, where it is directly connected to pollution control processes. Objectives of the program, in addition to supporting high-guality research, include stimulating technological inmovation, increasing the commercial applications of EPA supported research, and improving the retum on investment from federally funded research for tits exonomic and social benefits to the nation.

Phase I awards currently provide up to $\$ 65,000$ for six months to determine the small firm's concept feasibility and their capability to perform higb-quality research. Phase II awards, which currently provide up to $\$ 220,000$ for a period of one or two years, is the principal research effort for those projects that appear most promising after Phase I. Phase III is the procuct or process developrient phase to pursee commercial application, but no SBIR funds are provided in Phase III. In FY 1992, 41 Phase I awards were made which resulted in 21 Phase II awands in FY 1993. Also in FY 1993, 34 new Phase I awards were made. Sample project titles include:

- A Low Life-Cycle Cost UV Source and Reactor to Oxidize Aqueous Phase Organics

- Photo-Themal Conversion of CFCs and Halons to Valuable and Environmental Safe Materials

- Conversion of Waste Stream Plastics Into Polymer Matrix Composite Materials

- Waste Reduction Through Benzene-Free Polymerization Technology

- Novel Catalysts for the Low Temperature Oxidation of Volatile Organic Compounds.

Amount of funding anallable for chemical industry-related R\&D:

In FY 94, approximately $\$ 4.85$ million of awards were mede, and in FY 95, approximately $\$ 8.68$ million in awands were made.

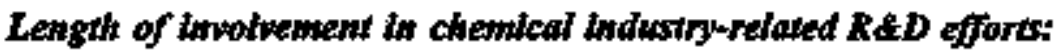

EPA's SBTR program has existed since 1983.

Relationship to OrT programs (ff applicable): None.

Notes:

Sources of information: $\quad$ Abstracts of Phase I and Phase $I I$ Awards (EPA 600-R-93-241). Persontal communication.

Date of last revislon: September 13, 1995. 



\section{NATIONAL AERONAUTICS AND SPACE ADMINISTRATION}

The National Aeronautics and Space Administration conducts research for the solution of problems of flight within and outside the Earth's atmosphere and develops, constructs, tests, and operates aenonautical and space veticles. It conducts activities required for the exploration of space with manned and unmenned vehicles and arranges for the most effective utilization of the scientific and engineering resources of the United States with other nations engaged in acronautical and space activities for peaceful purposes. 
National Aeronautics and Space Administrition

Office of Life and Microgravity Sciences and Applications

Microgrivity Science and Applications Division

Mail Code UG

NASA Headquarters

Washington, DC 20546

Contact $\quad$ Mr. Rabert C. Rhome, P.E; Director

Phone: 202-358-1490

Fax: $\quad$ 202-358-3091

E-mail: $\quad$ RRHOME@HQNASA.GOV

Description of agency involvement in chemical industy-related RRD:

The mission of the Microgravity Science and Applications Division is to use the mictogravity enviromment of space as a tool to advance knowledge; to use space as a laboratory to explore the nature of physical phenoment contributing to progress in science and technology on Earth; and to study the role of gravity in technological processes, building a scientific foundation for understanding the conseguences of gravitational environments beyond Earth's boundaries. The Microgravity Science and Applications Division conducts a program of basic and applied research in the areas of biocechnology, combustion, fluid physics, materials science, and selected areas of condensed matter and gravitational physics. Approximately 250 projects are currently being funded by this program. Sample project titles include:

- Protein Crystat Growth in Microgravity (biotectunology)

- Ignition and Flame Spread of Liquid Fuel Pook (combustion)

- Study of Two-Phese Flow and Heat Transfer in Reduced Gravities (fluid physics)

- Microgravity Chemical Vapor Deposition (material science)

Amount of funding avolloble for chemicat indusfrynelated R\&D;

The program budget in FY 1994 was $\$ 188$ million and in FY 1995 is \$170.I million.

Length of involvement in chemical indantry-related R\&D effort:

The program has existed since the iate 1960's, when it was known as Materials Processing in Space.

The Microgravity Science and Apptications Division was fomed in 1984.

Relationship to OIT prograns (if applienbile): None.

Notes:

Sources of information: Personal communication.

Merogravity Science and Applications: Program Tasks and Bibliogrophy for FY 1993, NASA Tectuical Mentorandum 4569, March 1994.

Date of tast reviston: July 13, 1995. 
National Aeronatitios and Space Administration

Office of Space Access and Technology

Space Processing Division

Mail Code XP

NASA Headquarters

Washington, DC 20546

Contact: $\quad$ Mr. Ed Gabris

Phore: 202-358-4577

Fax: 202-358-2886

E-mail: EGABRIS@HQ.NASA.GOV

Deseription of agency Lwolvememt in chemied industry-reloted R\&D:

The Office of Space Access and Technology is responsible for advanced techology development, technology transfer and commercial development of space. Managed by this office are 11 Centers for the Commercial Development of Space which are a nonprofit consontia of industry, academia and government designed to advance promising areas of space R\&D with commercial applications. The centers serve as incubators for space-related products and services and offer U.S. organizations excellent opportunities to perform low-cost, spacebased conmercial R\&D.

The program has focused areas of research, two such areas are biotechnology and materials processing. Sample projects from the biotechnology area are: bioprocessing/bioproduet development, physiological Fuodeling in space, controlled agriculture systems development, and determining the 3-dimensional structure of protein crystals. Sample projects from the materials processing area ire: space materials that can be used to build structures in space, liquid metal sintering, electrodeposition techrique, using the ultre-vacuum of space for processing ultra-pure, thin film materials for electronics and computers.

Amownt of funding avalioble for chentical industry-reloted Rd ;

In addition to an annual NASA-base grant funding of up to $\mathbf{\$ 1}$ million, the centers receive financiaj and in-kind contributions from industry, universities, research institutions and federal, state and local organtizations.

Length of involvenent in chemical indutry-related R\&D fifors:

The program was establisked in 1985.

Relationship to OIT prograns of appitcable) None.

Notes:

Sources of information: Personal communication.

Date of last revision: September 29, 1995. 


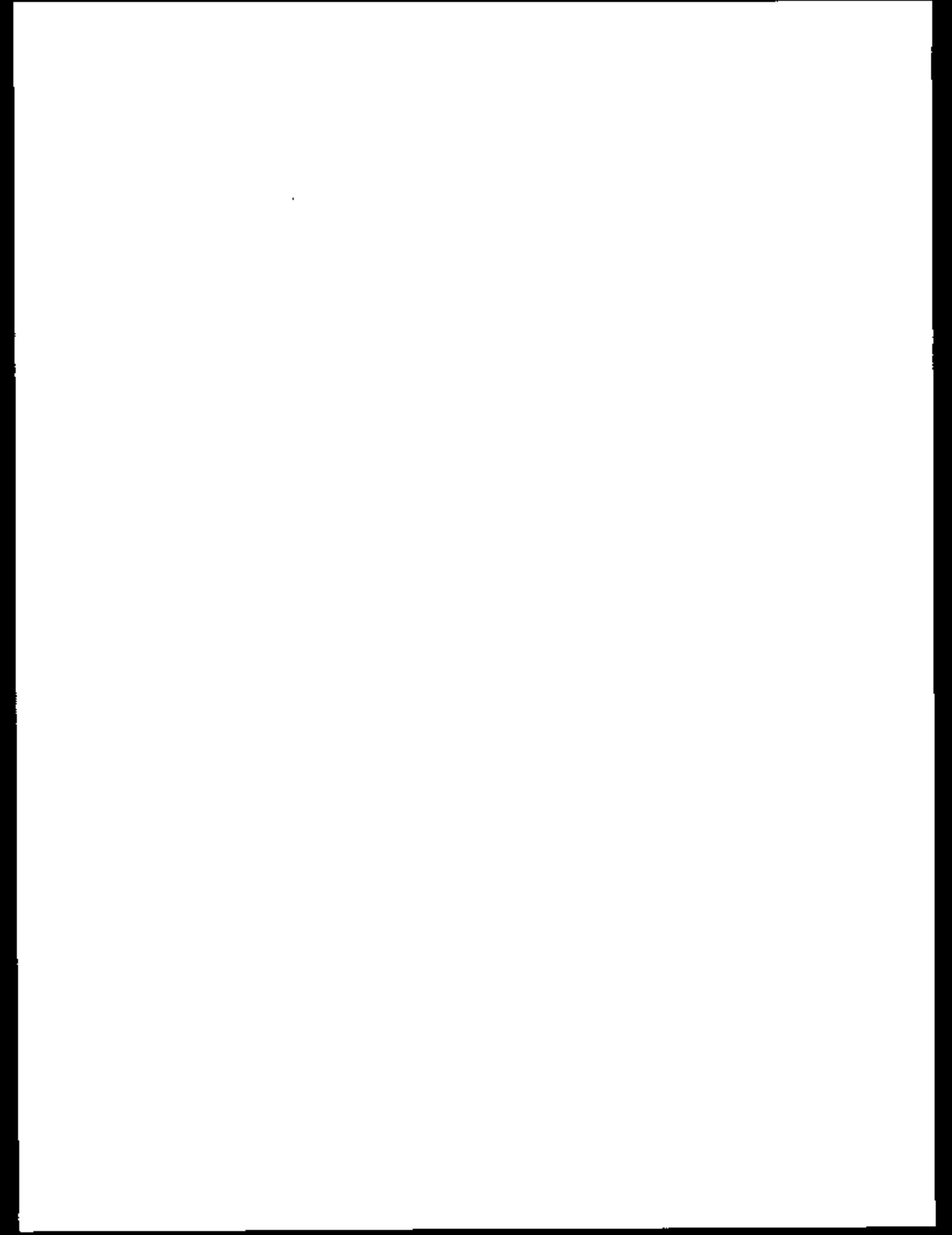




\section{NATIONAL SCIENCE FOUNDATION}

The National Science Foundation promotes the progress of science and engineering through the support of research and education programs. Its major emphasis is on high-quality, merit-selected research - the search for improved understanding of the fundamental laws of nature upon which our future well-being as a nation depends. Its educational programs are aimed at ensuring increased understanding of science and engineering at al] educational levels, maintaining an adsquate supply of scientists and engineers to meet our country's needs. 
National Science Foundation

Bioengineering and Environmental Systems Division

420 | Wilson Blvd., 565

Arlington, VA 22230

Contact: $\quad$ Ms. Janie Fouke, Dinector

Phone: 703-306-1320

Fax: $\quad$ 703-306-0312

E-mail: JFOUKE@NSF,GOV

Descriotion of agency involvement in chenical industry-related RAD;

The Bioengineering and Environmental Systems Division is concemed with expanding the knowledge base of bioengineering; extending engineering methodologies to the solution of problems in the biological and medical sciences; employing biological principles for the development of innovative engineering methods and systens; improving our ability to apply engituenting principles to correct problems that impair the usefulness of land, air, and water; and exploring basic engineering concepts in the development, conservation, and use of ocean resounces and systems. Research activities in this division relevant to the chemical industry include biochemical engineering biotechnology and envirommental systems.

Biochemical engineering supports the research and development of traditional fermentation and recombinant DNA processes for manufacturing substances of biological origin. Projects are supported that utilize biological microorganisms for the transformation of organic, raw materials (biomass) into nsefiul products, and for the process enginecring of foods. Downstream processing is becoming increasingly important as new advances in separation and purification technologies accelerate. Process integration, optimization, and design utilizing advanced monitoring and control methods are also very important.

Biotechnology links the expentise of engineering with the life sciences in order to provide a fundamental basis for the economical manufacturing of substances of biological origin. Engineers working together with life scientists on group projects ane supported by this part of the program. Synerzy among the various disciplines in these types of projects is a very important ovaluation criterion. Topic areas include, but wre not limited to, cell culture systems; bioreactor design; separation and purification processes; monitoring and control methods; and process integration, optimization, and design.

Environmental Systems supports research, the abjective of which is to discover and leart how to apply engineering primciples to reduce adverse effects of solid, liquid, and gaseous discharges to land, water, and air that impair their resource values. The program also supports research on innovative biological, chemical, and physical processos used alone or as components of engineered systems to restore the usefulness of polluted land, water, and air resources.

Amount of funding awallable for chemical industry-related RAD;

For FY 94 and FY 95, approximate funding in the environmental systems arex was \$4.5 million each year, and approximate funding in the biochemical engineering and biotechology areas was around $\$ 7$ million each year. 
Length of involvement in chemical irdustry-velated RAD efforts:

The Bioengineering and Environnental Systems Division was formed about 3 years ago. Similar research efforts existed under a predecessor organization.

Relationship to OTT pregrans (f) applicablej: None.

Notes:

Sources of information: Personal communication. Internet resources.

Other contacts:

Biotechnology and biochemical engineering: Mr. William Weigand 703-306-1319 WWEIGAND@NSF.GOV

Environmental systems: Mr. Edwart Bryan 703-306-1318 EBRYAN@NSF.GOV

Date of last reviston: September 26, 1995. 
National Science Foundation

Chenical and Transport Systems Division

4201 Wilson Blvd., Room 525

Arlington, VA 22230

Contact: Dr. Kenneth R. Hall

Phone: $\quad$ 703-306-1371

Fax: $\quad$ 703-306-0319

E-mail: KHALL@NSF.gOV

Description of agency intotvenent in chemical industry-related R\&D;

The Chemical and Transport Systems Division of the National Science Foundation (NSF) funds fundamertal research into the niture of chemical systents. The gentral areas include: catalysis, reaction engineering transpoit phenomens, interfacial phenomena, thermal processes, themodynamics, separations, design theory, control of chemical systems, electrochemical phenomena, biochemical applications, and upstremm envircnmental considerations.

At any given time the division has abour 300 active projects. The ustzal size of a projeat is about $\$ 75,000$ per year. The division makes an effort to fund new investigators as well as established investigators. Nearly all investigators are faculty members in U.S. univerșities.

Anount of funding awailable for chemical industry-related ReD:

The yearly division budget is approximately $\$ 40$ million.

Length of involvement in chemical hidustry-related $\mathrm{R} A \mathrm{D}$ efforts:

The division has existed at NSF under vartous titles since the early $1960 \mathrm{~s}$.

Relationship to OIT programs (ff applicable): None.

Notes:

Sources of information: Personal communication.

Date of last revision: August 7, 1995. 
National Science Foundation

Chemistry Division

420I Wilson Blvd, 1055

Arlington, VA 22230

Contact: Ms. Janet Osteryoung

Phone: $\quad$ 703-306-1845

Fax: $\quad$ 703-306-0534

E-mail: $\quad J O S T E R Y O @ N S F . G O V$

\section{Deseription of agency iavohenent in chemical indwstry-related RED;}

Programs of the Chemistry Division support research activities and research infrastucture development in most of the principal subdisciplines of the chemical sciences. Chemistry Division programs also support research activities in emerging areas of national inturest that cut across "traditional" subdisciplines. These areas include biological chemistry, materials chemistry, computational chemistry. environmental chemistry, and chemical complexity. Many of these activities are part of the government-wide research programs coordinated under the Federal Coordinating Council for Science, Engineering, and Technolagy.

Division programs and initiatives include: Analytical and Surface Chenistry; Inorganic, Bioinorganic, and Organometallic Chemistry; Organic Chenical Dynamics; Otgenic Synthesis; Experimental Physical Chemistry; Theoretical and Computational Chemistry; Special Projects Office; and Chemical Instrumentation and Facilities.

In both FY 94 and FY 95, the division supported almost 1,000 individual project research grants. The average grant continues for 36 months at about $\$ 110$ thousand per year.

Amount of funding avallable for ckenteal industrorelated RdD;

In FY 94, the division's funding was approximately $\$ 120$ million, and in FY 95, the division's funding was approximately $\mathbf{S 1 2 1}$ million.

Length of inwohenew in chewical industry-related RAD efforts:

Related efforts begar in the earfy 1950s, around the same time the National Science Foundation was founded.

Relationshlp to OT prograns (ff applicable): None.

Notes:

Sources of information: Personal communication.

Internet resources.

Date of last reviston: September 26, 1995. 
Nationsl Science Foundation

Design, Manufacture, and Industrial Innovation Division

4201 Wilson Blvd., 550

Arlington, VA 22230

Contact: Mr. Bruce Kramer, Director

Phone: $\quad 703-306-1330$

Fax: $\quad 703-306-0298$

E-mail; $\quad$ BKRAMER@NSF.gOV

Descripton of agency involvement in chemical industry-related R\&D;

The goal of this division is to support research that seeks to serve a broad spectrum of American industry through developing and expanding the scientific and engineering foundations of design, manufacturing, prodkxtion, integration engineering, and management of technological innovation. Long.term efforts are needed to deepen onr understanding of the processes, operations, and systems that comprise modem manufactiring, and to make our narufacturing base mose competitive by increasing its innovation and responsiveness to changing needs. Support of the development of operations research methodologies that underlie the full range of enginetring systems for production complements these efforts.

The National Science Foundation (NSF) has always been acutely aware of the relationships between industrial development, technological innovation, and scientific research. The diviston provides a focks for small business activities of the National Science Foundation and administers the NSF Small Busimess Innovation Research (SBIR) Program. Sample topies of recent SBIR research inchude:

- High speed gas chromatography

- Novel modified fluoropolymeric materials

- New production technology for ethylene glycol

- Innovative processing for production of fullerenes

Amount of funding awilable for chemical industry-related R\&D:

Estimated funding for chemical industry-related R\&D was $\$ 3.2$ mjllion for FY 94 and FY 95.

Langth of involvement th chemical industromelated RdD eforts:

The SBIR program has existed since the late 1970's at NSF.

Relationshtp to OrT progrants (ff applicable): None.

Notes:

Sources of information: Personal communication. Internet resources.

Date of last revision: August 14, 1995. 
National Science Foundation

Materials Research Division

4201 Wilson Blvd., 1065

Arlington, VA 22230

Contact: Mr. David Nelson

Phone: $\quad$ 703-306-1838

Fax: $\quad$ 703-306-0515

E-mail: DNELSON@NSF.GOV

Description of agency thwohement in chemicol industry-related R\&D:

The Division of Materials Research supports a wide range of programs that address fundarnental phenomena in materials, materials synthesis and processing materials stucture and composition, materials properties and performance, and miterials education. Formal research program areas include Condensed Matter Physics; Solid-State Chenistry and Polymers; Metals, Ceramics, and Electronic Materials; Materials Theory; and Materials Research Science and Engineering Centers. Investments in research infiastructure in materials science ane also made through the National Facitities and Inștrumentation Program.

As an example, the Solid-State Chemistry and Polymers Program is largely experimental and multidisciplinery with strong components of chemistry, physies, and materials science. The program enphasizes synthesis, processing characterization, and struchure property relationships of materials at the molecular level, with special attention to new materials or materials with superior properties. The solid-state chemistry program component supports research in the following treas: irmovative synthetic routes to new inorganic and organic solid-state and mesophase matarials; characterization of new materials with novel electronic, optical, magnetic, and chemical behavior, relationships among balk, surface, interfice, and defect structures, and properties such as chemisonption, transport, and reactivity; and materials preparation, processing and optimization by chemical means. The creation of new materials exhibitting new phenomena is emphasized within selected classes of advanced materials such as biomolecular, magnetic, and superconducting materials, and with emphasis on special issues such as envirommental concens related to the processing and utilization of potentially functional materials.

Amount of funding awallable for chemical industry-retated R\&D:

Approximate division funding in FY 94 was $\$ 167.2$ million, and approximate division funding in FY 95 was \$175.4 million.

Length of involvement in chemical indostry-related ReD efforts:

The division has been involved in related efforts since 1972.

Relationship to OTT programs (ff appiticable): None.

Notes:

Sourees of information: Personal communication.

Internct resources.

Date of last revision: September 7, 1995. 
National Science Foundation

Molecalar and Cellular Biosciences Division

Biochemistry and Molecular Structure and Function Program

420! Wilson Blvd.

Arlington, VA 22230

Contact: $\quad$ Dr. Marcia Steinbers

Phone: 703-306-1443

Fax: 703-306-0355

E-mail: MSTENBE@NSF.GOV

Description of agency inwolvement in chemicat industry-related RdD:

The Biochemistry and Molecular Structure and Function Program supports basic research aimed at: (1) understanding the structure and function of biological macromolecules; and (2) the characterization and regalation of biochemical pathways and other celiular processes. At any given time, the program supports about 400 projects through grants. The program encompasses a wide range of research topics and tectmiques and is divided into the three sub-programs described below.

The Metabolic Biochemistry Sub-Program supports research on the characterization and regulation of biochenical pathways and other processes by which microbes, and plant and animaj cells transport, assimilate and derive energy from substrates. Exploration of primary and secondary metabolism at the levels of gene expression and enzyme function and regulation are major topics considered. Research on biogeochemical cycies and degradation of polymers and xenobiotics is also supported.

The Molecular Biochetnistry Sub-Program supports rescarch aimed at understanding the structure and function of biological macnomolecules, and the molecular basis of their interactions. Areas of interest include proteins, nucleic acids, polysacharides, and lipid aggregates. Studies are supported which consider: the molecular basis of the mexhanism and regulation of enzyme catalysis; bioenergetics and photosynthesis; protein synthesis and ribosome structure; protein and nucleic acid synthesis; supramolecular complexes; and the synthesis and properties of bionolecular materials.

The Molecular Biophysics Sub-Progran supports research on the strucaure, dynamics and interactions of biological macromolecules (proteins, nucleic acids, lipid assemblies, polysaccharides, etc.), utilizing advanced physical techniques. Areas of interest include: the three dimenstional structure of macromolecules; the relationship between structure and finction; assembly and architecture of supramolecular structures (e.g., multienzyme units, viruses, membranes and contractile proteins); energy transouction; structure and function of photosynthetic resction centers; and mechanisms of electron transfer in biological systems. Typical approaches and techniques include: electron microscopy; diffraction; scattering; x-ray absorption, magnetic resonance, infra-red, and other spectroscopies.

Amoant of fanding apallable for chemical lidustry-related RAD:

In FY 95, the program received funding of approximately $\$ 28.7$ million.

Length of involvement in chemical indastry-retated R\&D efforts:

Involvement in related efforts have existed since the beginning of NSF in the 1950's. 
Relationshtp to OIT prograns $(f$ appllcable): None.

Nores:

Sources of information: Personal communication. Internet resousces.

Date of last revision: August 29, 1995. 



\section{TENNESSEE \\ VALLEY AUTHORITY}

The Tennessee Valley Authority conducts a unified program of resource development for the advancement of economic growth in the Tennessee Valley region. The Authority's program of activities includes flood control, navigation development, electric power production, fertilizer development, recreation improvement, and forestry and wildlife development While its power program is financially self-supporting, other programs are financed primarily by appropriations fromi Congress. 
Tennessee Valley Authority

Environmental Research Center

Post Office Box 1010

Muscle Shoals, AL 35662-1010

Contact: Mr. Keith Rylant

Phone: 205-386-2835

Fax: 205-386-2049

E-majl: Unknown

Description of agency intolventent in chemical industry-related R\&D:

The Tennesse Valkey Authority (TVA) Environmental Research Center provides full-scale scientific applications devetoped from bench-scale research. The Center's staff offers research applications in areas such as ozone mitigation, pollution prevention, site remediation, and biotechnology.

Areas of chemical industry-related R\&D are air quality monitoring, agrichemicals, biofilters, composting, bioremediation, and chemical remediation.

Sample project titles and participation include:

- Construkted Wetlands (Department of Defense, Corps of Engineers, EPA)

- Coal Refinery (TVA)

- Pollution Prevention for Agrichemical Dealers (EPA, state regulators, agri dealers associations)

- Biofilters (private sector)

- Acid Recycling (DOE)

Amownt of fanding available for chemical industpp-related ReD; Unknown.

Length of inwolvement in cheraical industy-related R\&D effors: Unknown.

Relotionship to OT prograns (of applicable): None.

Notest

Sources of information: Personal communication.

Date of lost rewtslon: August 10, 1995. 


\section{AVAILABUL INTERNET HOME PAGES FOR ADDTTIONAL INRORMATION}

\begin{tabular}{|c|c|}
\hline Depertiment of Aquicotione & beted/www, usdagev \\
\hline A gricaliturall Restarch Service & 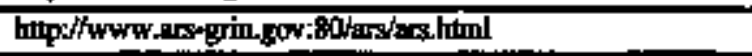 \\
\hline Cocperalive Statit Research Service & 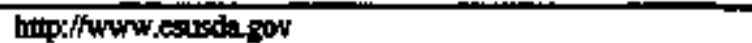 \\
\hline Fostest Service & hofp:/www.fs.fodes \\
\hline Depertmeat of Commerse & 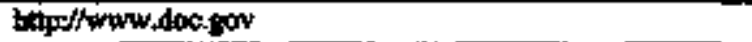 \\
\hline Bution of the Censos & twww.cenour gov \\
\hline Nentinnal Institute of Sreadeds and Fechnology & 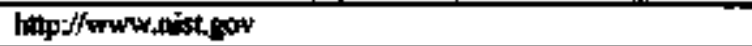 \\
\hline Adranod Techology Program & 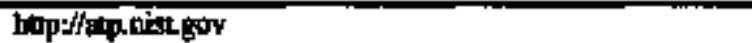 \\
\hline 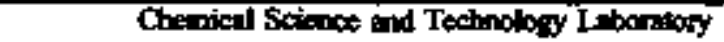 & 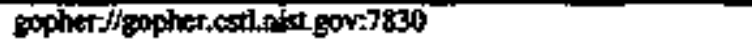 \\
\hline Materials Scieuce and Engineering baboritory & 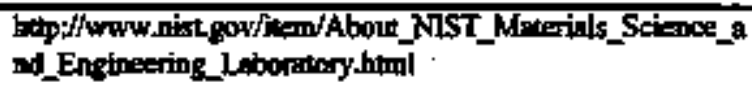 \\
\hline Deprotment of Detionste & 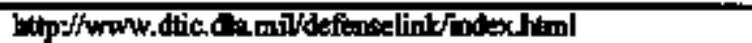 \\
\hline Advanced Researth Profects Agercy & hap:thww,eqpamit \\
\hline Defienes Stenof Office & hatp//rebhost.sainc.com/apo/dso \\
\hline Tectunology Reinvestment Project & 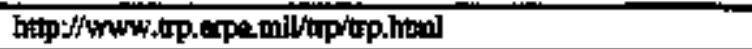 \\
\hline Depertinent of the Air Fanse & hatp: $/$ www.af.mil \\
\hline Office of Scientific kneseanch & 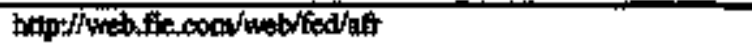 \\
\hline Departmeat of the Army & 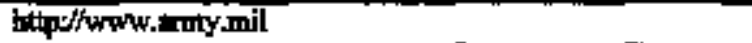 \\
\hline Army Reseirch Laborangy & 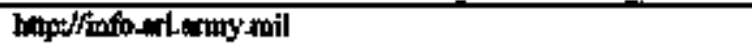 \\
\hline Departined of the Nmy & bothp/www.nawy.mil \\
\hline Ofine of Naval Researth & 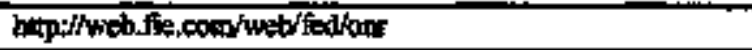 \\
\hline Small Business Invovation Restinct Program & 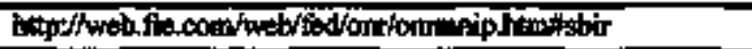 \\
\hline $\begin{array}{l}\text { Stratogic Exwionmont Research and Development } \\
\text { Program }\end{array}$ & 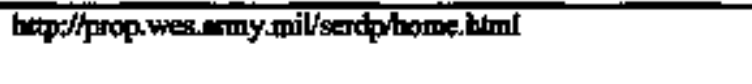 \\
\hline Depertmen of Enery & htpp:/hwowdoegov \\
\hline Office of Energy Eficiency and Renewablo Energy & hepi/Www.erendioe.gow \\
\hline Ofifies of Indertital Technologies & 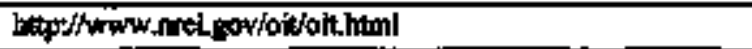 \\
\hline Office af Building Tectunologies & 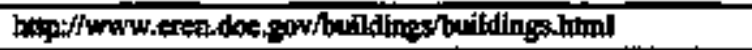 \\
\hline Oftice of Trinspoctation Technolotics & 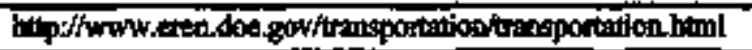 \\
\hline Office of Utility Tecturologites & 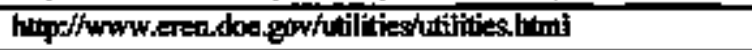 \\
\hline Office of Energy Resegroch & 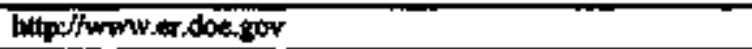 \\
\hline Basic Eneray Sciences & 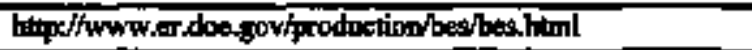 \\
\hline Advanced finergy Projects Divition & 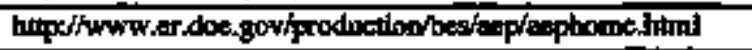 \\
\hline Chemich Selepcos Division & 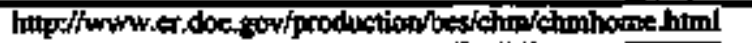 \\
\hline Entry Bloscteroess Dwistion & 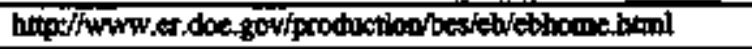 \\
\hline Smell Business tonovation Research & Extlp $/ / 146.138 .5 .107 /$ stit. Ktam \\
\hline 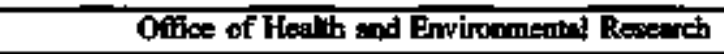 & hedp://twww.er.doe.gow/poduction/obed/oher_top.himl \\
\hline 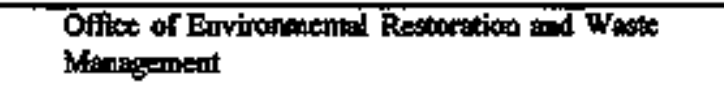 & 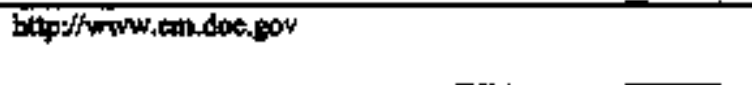 \\
\hline Ofing of Foss Ensty & 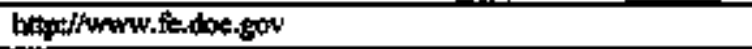 \\
\hline Depertment of Healith and Humen Servioes & butpothww.0s dhhs.gor \\
\hline Public Healih Serviat & 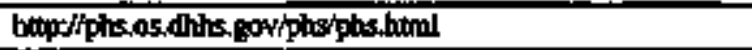 \\
\hline $\begin{array}{l}\text { Agency for Tomic Substences end Disenso } \\
\text { Requistry }\end{array}$ & 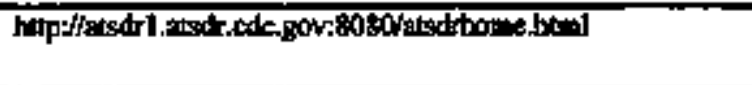 \\
\hline
\end{tabular}




\begin{tabular}{|c|c|}
\hline Centars for Disease Control & hips/fanwwedkgov \\
\hline $\begin{array}{l}\text { Notionel Center for Envirionmedtal } \\
\text { Hes'th }\end{array}$ & 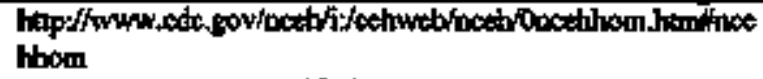 \\
\hline $\begin{array}{l}\text { National Itstiput for Occupational } \\
\text { Sofety and Healh }\end{array}$ & hatpof/hww.codegovintoshlhomepagthinil \\
\hline Food and Drug Adninistration & 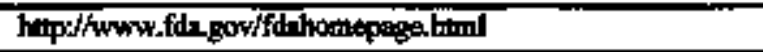 \\
\hline $\begin{array}{l}\text { National Center for Toxicological } \\
\text { Researeh }\end{array}$ & gophurt/gophat.nctr.Ida-gov \\
\hline National Instinttes of Health & 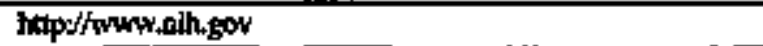 \\
\hline $\begin{array}{l}\text { National Instinte of Eminonmenalal } \\
\text { Health Sciences }\end{array}$ & htop/hwww, sictets, nith,gov \\
\hline $\begin{array}{l}\text { National Instinute of General Medical } \\
\text { Sciences }\end{array}$ & htip $/$ hww nih.gow/nigms \\
\hline Deparment of the Interior & hatpofhwww, dusgos, gow/dos \\
\hline Bureall of Mints & httpdrwwa.lestom.gor \\
\hline Center for Polition Prevention and Coctrol & 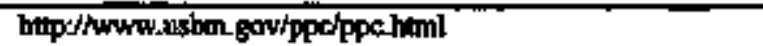 \\
\hline Department of Transportation & hutp/toww,dot.gov \\
\hline Federal Hïghway Aduinistration & 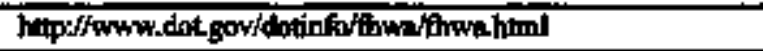 \\
\hline Enviroumeatal Ptotecton Agancy & 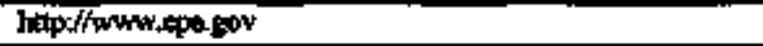 \\
\hline Office of Prevention, Pesticides and Toxic Substances & 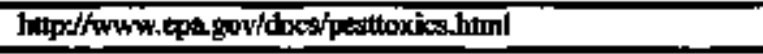 \\
\hline 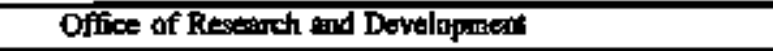 & 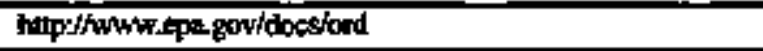 \\
\hline 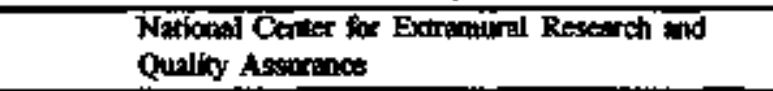 & 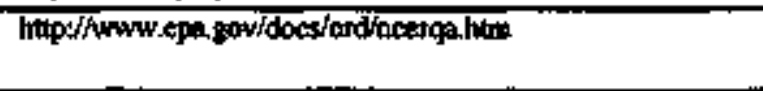 \\
\hline Kationel Rist Managenent Research Lahontory & 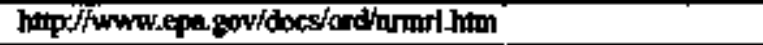 \\
\hline National Acromentiks and Spece Administration & 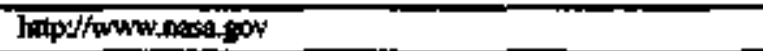 \\
\hline Mierogravity Sciences and Applicattons Divition & 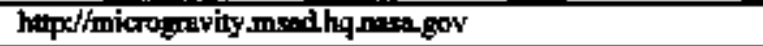 \\
\hline Office of spact Acosss and Technology & 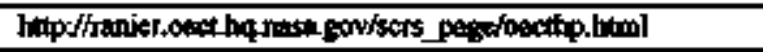 \\
\hline Natiknal Science Formdintion & 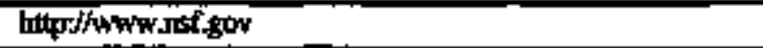 \\
\hline Blocoginetring and Envirmmerted Systens Division & 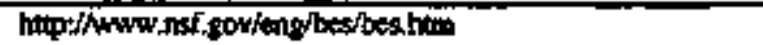 \\
\hline Chenital ind Transpoct Systens Division & httpl/www.nsf.gowieng/cts/ds.thm \\
\hline Cheanikiny Divistion & 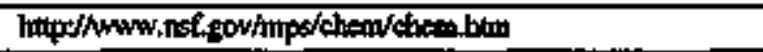 \\
\hline Design, Marufactute, and Endustrias Enowation Divioion & http/hwww.nsfigowheng/drejt/dmithtm \\
\hline Moterials Research Division & 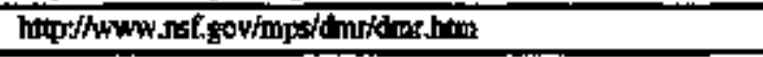 \\
\hline Molecullar ad Cethrlar Btosciences Division & 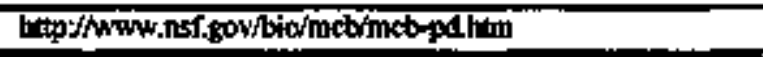 \\
\hline
\end{tabular}




\section{ACRONYMS}

\begin{tabular}{|c|c|}
\hline AEP & Advanced Energy Projects \\
\hline ARPA & Advanced Research Projects Agency \\
\hline ARS & Agricultural Research Service \\
\hline ATP & Advanced Techmology Program \\
\hline ATSDR & Agency for Toxic Substances and Disease Registry \\
\hline CDC & Centers for Disease Control and Prevention \\
\hline $\begin{array}{l}\mathrm{CO}_{2} \\
\mathrm{CRADA}\end{array}$ & $\begin{array}{l}\text { Carbon Dioxide } \\
\text { Cocperative Research and Development Agreement }\end{array}$ \\
\hline CSRS & Cooperative State Research Service \\
\hline DEE & Design for the Errvironment \\
\hline DNA & Dexxyribonucleic Acid \\
\hline DOA & Department of Agriculture \\
\hline DOC & Department of Commerce \\
\hline DOD & Department of Defense \\
\hline DOE & Department of Energy \\
\hline DOI & Department of the lnterior \\
\hline DOT & Department of Transportation \\
\hline DSO & Defense Sciences Office \\
\hline EPA & Environmental Protection Agency \\
\hline ETI & Environmental Techoology Initiative \\
\hline FAA & Federal Aviation Administration \\
\hline FDA & Food and Drug Administration \\
\hline FSIS & Food Safety and Inspection Service \\
\hline FY & Fiscal Year \\
\hline IR & Infrared \\
\hline METC & Morgantown Energy Technology Center \\
\hline MSEL & Materials Science and Engineering Labotatory \\
\hline NASA & National Acronautics and Space Administration \\
\hline NATO & North Atlantic Treaty Organization \\
\hline NCEH & National Center for Envirommental Health \\
\hline $\mathrm{NlCE}^{3}$ & National Industrial Competitiveness through Energy, Environment, and Economies \\
\hline NIEHS & National Institure of Environmental Health Seiences \\
\hline NGMS & National Institute of General Medical Sciences \\
\hline NIH & National Institutes of Health \\
\hline NIOSH & National Institute of Oceupational Safety and Health \\
\hline NIST & National Institure of Standards and Technology \\
\hline NMR & Nuclear Magnetic Resonance \\
\hline NRMRL & Nations Risk Management Reseanch Laboratory \\
\hline NSF & Nations] Science Foundarion \\
\hline OBT & Office of Building Technologies \\
\hline OIT & Office of Industrial Technologies \\
\hline OUT & Office of Utitity Technologies \\
\hline PCB & Polychlorinated Bjphenyl \\
\hline PETC & Pittsburgh Energy Technology Center \\
\hline
\end{tabular}


R\&D Research and Development

RCRA

Resource Conservation and Recovery Act

SARA

Superfund Anendinents and Reauthorization Act

SBIR

Small Business Innovation Research

SBRP

Superfund Basic Rescarch Progran

SERDP

Strategic Environmental Research and Developsnent Program

SIC

STTR

TRP

Standard Industrial Classification

TVA

Small Business Technology Transfer

UV

Technology Reinvestment Project

Tennessee Valley Authority

Voc

Ultraviolet

Volatile Organic Compound 


\section{REFLRENCES}

The United States Government Mantual 1994/5; Office of the Federal Registrar, National Archives and Records Administration.

National Toxicology Program Fuscal Year 1994 Anmal Plat; U.S. Departmeat of Health and Human Services, Public Health Service; May 1994.

Summary of FY 1994 Research in the Chemical Sciences; U.S. Department of Energy, Office of Energy Research, Division of Chemical Sciences; September 1994; DOE/ER-0144/12.

Research Interests and Broad Agency Amotolement 95-1 of the Atr Force Office of Scientific Research; October 1994; AFOSR Pamphlet 70-1.

Abstracts of Phate I and Phave II Awand, Small Business Innovation Research Progran J993; U.S. Environimental Protection Agency, Research and Development; January 1994; EPA 600-R-93-241.

Amud Report of the Research Grants Program 1994, Office of Exploratory Research; U.S. Emvironmental Protection Agency, Research and Development; Janwary 1995; EPA 600-R-94-158.

NCTR Research Accomplishments and Plans FY 1994-J995; National Center for Toxicological Research.

Research in Progress: FY 1992, Summaries of Profects Sponsored by the Office of Heallh and Environmental Research; U.S. Department of Energy, Office of Energy Research, Office of Health and Envitonmental Research; August 1993; DOE/ER-0592.

Annud Report and Activities of FY 1994 Acthities, Division of Energy Biasciences, U.S. Department of Energy, Office of Energy Reseach, Division of Energy Biosciences; September 1994; DOE/ER-062IP.

1994 Ammal Report and Five-Yer (1994-1998) Strategtc Imvestment Plon, Strategic Environmental Research and Development Program; September 1994.

New Industrial Uses, New Marikets for U.S. Crops: Storus of Techology and Commercial Adoption; U.S. Department of Agriculture, Cocperative State Research Service; August 1993.

Technology Parnerships; U.S. Department of Energy, Office of Industrial Technologies; April 1995; DOE/GO-10095-170.

Small Business bnowation Research (SBIR) Phase I and Phase II Projects Abstracts Book, Fiscal Year 1994; U.S. Department of Health and Human Services.

Air Force SBIR, An Opportumity for Small Business; U.S. Air Force.

Chemical Science and Technology Laboratony Techical Activities 1994; U.S. Department of Commerce, National Institute of Standands and Technology; March 1995; NISTIR 5584. 
Advanced Technology Progrom Proposal Preparation Kit; U.S. Department of Commerce, National lnstitute of Standards and Technology; November 1994.

NBT Chemical Science and Techoology Laboratory Brochere; U.S. Department of Commerce, National Institute of Standards and Technology; March 1995.

Materials Scitence and Engineering Laboratory J994 Anmal Report; U.S. Department of Commere, National Institute of Standards and Technology; April 1995; NISTIR 5577.

Other Materials Sclence ond Engineering Laboratory Techical Activities 1994 Reports; U.S. Department of Commerce, National Institute of Standards and Technology; April 1995; NISTIR 5578, 5579, 5580, 5581,5582 , and 5583 .

Mftrogravity Science and Applications Progran Tasks and Bibliognaphy for FY 1993; National Atronautics and Space Administration; March 1994; NASA Technical Memorandum 4569. 


\section{Update Form}

Please use this form to make updates and/or corrections to information conceming your programs, or attach separite shert.

If your organization is involved in chenical industry-related R\&D and does not appear in this document, and would like to be included in the next edition, please complete this form and mati to:

\section{Brece Cranford}

U.S. Department of Energy

Office of Industrial Texhnologits, EE-20

1000 Independence Ave. $\mathrm{SW}, 5 \mathrm{~F}-043$

Washington, DC 20585

ContoctAgeng: (Please indicate: Contact Name(s), Titte, Agency, Address, Telephone, Fax, E-mail)

Descrlption of agency inoolvement in chemicol industry-related R ED: (Please give a brief description of agency's mission and activities. Also include detailed information reganding the chemical industryrelated R\&D efforts, including achievements and publications.)

Amoun of funding avallable for chemical industry-related R\&D; (Indicate available funding for these efforts by fiscal year.)

Length of involvement ts chemical industry-retated RdD efforts: (Indicate when work began or will begin, date of anticipated completion, or if work is continuous.)

Relationshlp to OrT programs (If applicable): (Please indicate if program has direct involvement with the Office of Industrial Technologies.)

Nates: (Other pertinent information not previously included.) 



\section{NDEX}

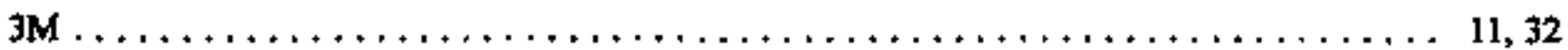

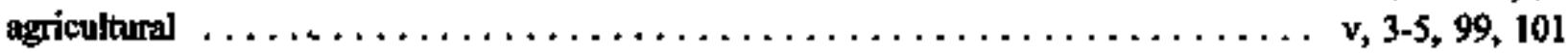

Agriculural Reserich Service $\ldots \ldots \ldots \ldots \ldots \ldots \ldots \ldots \ldots \ldots \ldots \ldots \ldots \ldots \ldots, 4,4,99,101$

AgriculfaIre $\ldots \ldots \ldots \ldots \ldots \ldots \ldots \ldots \ldots \ldots \ldots \ldots \ldots \ldots$ iii, v, 2-6, 8, 35, 75, 85, 99, 101, 103

Ait Force $\ldots \ldots \ldots \ldots \ldots \ldots \ldots \ldots \ldots \ldots \ldots \ldots \ldots \ldots \ldots \ldots \ldots \ldots, 17,19,21,22,99,103$

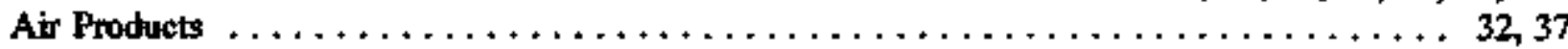

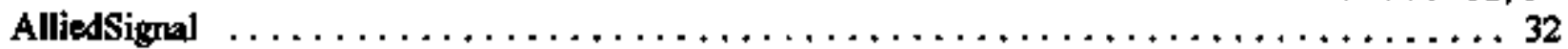

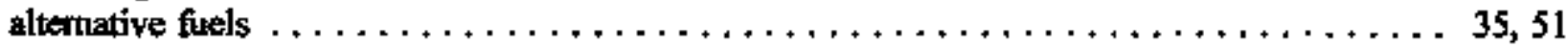

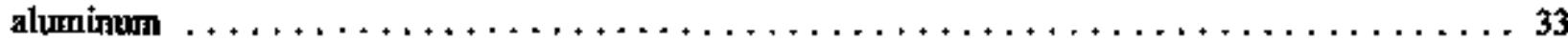

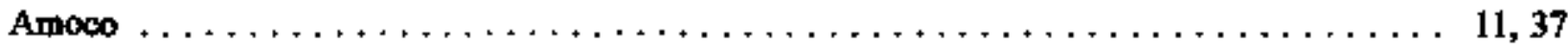

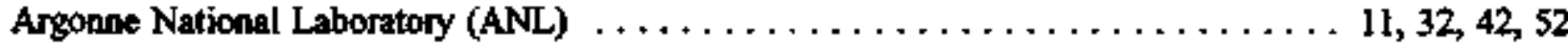

Anny $\ldots \ldots \ldots \ldots \ldots \ldots \ldots \ldots \ldots \ldots \ldots \ldots \ldots \ldots \ldots \ldots \ldots \ldots \ldots \ldots \ldots \ldots \ldots \ldots, 17,19,23,24,99$

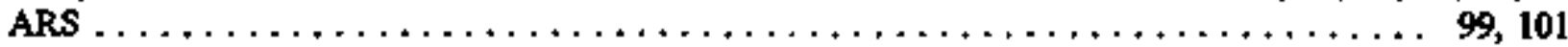

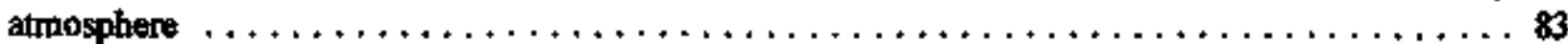

ATMOSPHERIC EMISSION ISSUES

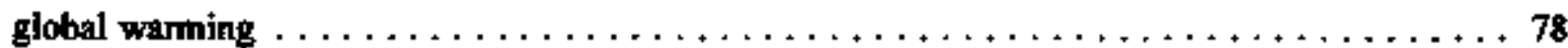

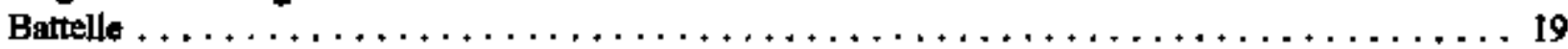

Biocatalysis $\ldots \ldots \ldots \ldots \ldots \ldots \ldots \ldots \ldots \ldots \ldots \ldots \ldots \ldots \ldots \ldots \ldots \ldots \ldots, 12$

biochemical $\ldots \ldots \ldots \ldots \ldots \ldots \ldots \ldots \ldots \ldots \ldots \ldots \ldots \ldots \ldots \ldots \ldots$ 44, 58, 88-90,94

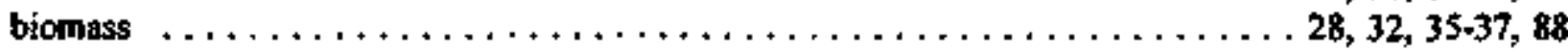

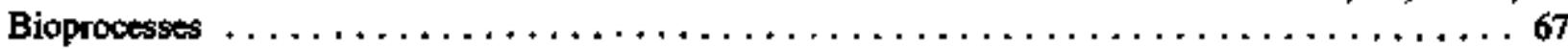

Biotechnology $\ldots \ldots \ldots \ldots \ldots \ldots \ldots \ldots \ldots \ldots \ldots 13,14,35,36,48,62,84,85,88,89,98$

Bureat of Mines $\ldots \ldots \ldots \ldots \ldots \ldots \ldots \ldots \ldots \ldots \ldots \ldots \ldots \ldots \ldots \ldots \ldots$ vi, 66-68, 100

Bureau of the Census $\ldots \ldots \ldots \ldots \ldots \ldots \ldots \ldots \ldots \ldots \ldots \ldots \ldots \ldots \ldots \ldots, 10,99$

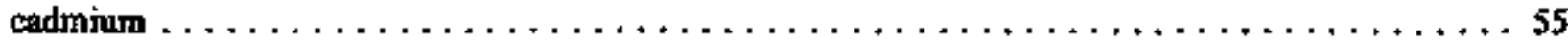

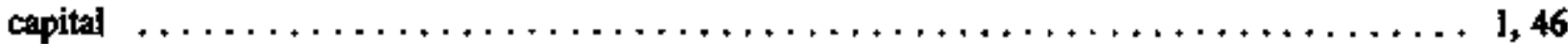

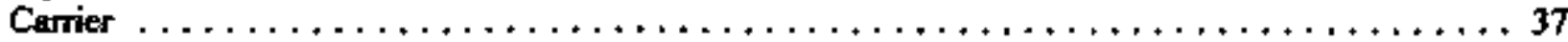

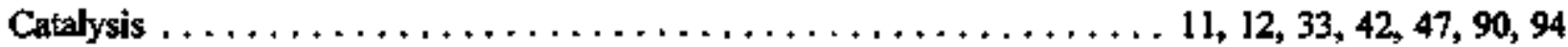

Centers for Disease Control and Prevention (CDC) $\ldots \ldots \ldots \ldots \ldots \ldots \ldots \ldots \ldots \ldots$ 54, 56, 99-101

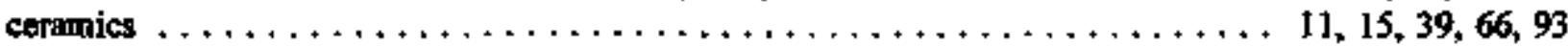

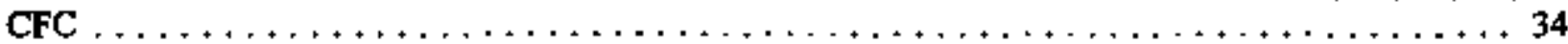

chemical engineering $\ldots \ldots \ldots \ldots \ldots \ldots \ldots \ldots \ldots \ldots \ldots \ldots \ldots \ldots \ldots \ldots \ldots \ldots \ldots \ldots \ldots \ldots, 42$

Chemical Sciences $\ldots \ldots \ldots \ldots \ldots \ldots \ldots \ldots \ldots \ldots \ldots \ldots \ldots \ldots \ldots \ldots$ vi, 42, 43, 91, 99, 103

Cleaping $\ldots \ldots \ldots \ldots \ldots \ldots \ldots \ldots \ldots \ldots \ldots \ldots \ldots \ldots \ldots \ldots \ldots \ldots \ldots \ldots, 32,39,72,78,80$

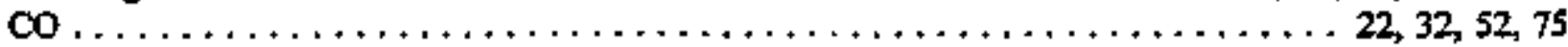

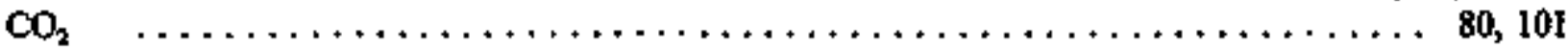

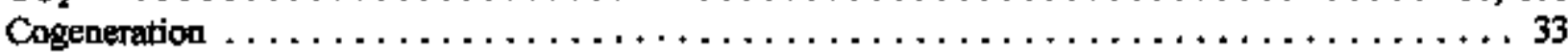

commercial $\ldots \ldots \ldots \ldots \ldots \ldots \ldots \ldots \ldots \ldots \ldots \ldots \ldots \ldots \ldots \ldots, 34,46,81,85,103$

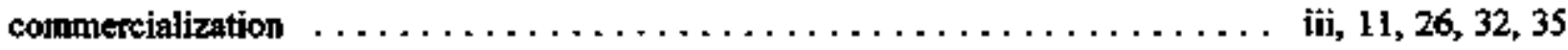

COMPANIES

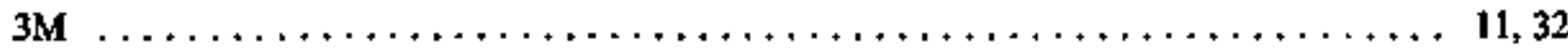

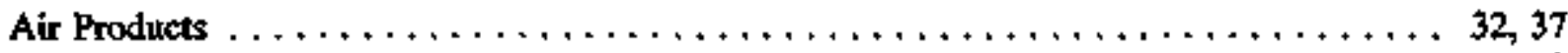

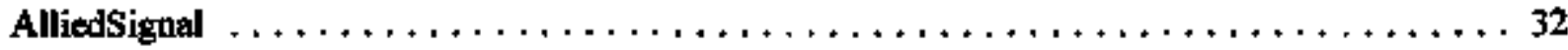

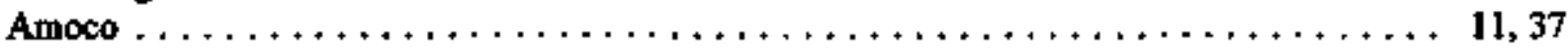

$\begin{array}{ll}\text { September 29, } 1995 & 107\end{array}$ 


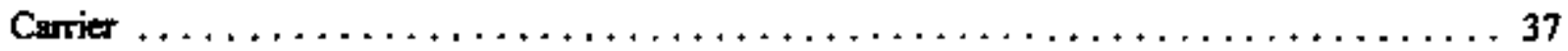

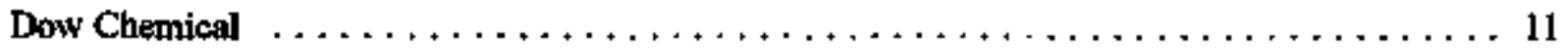

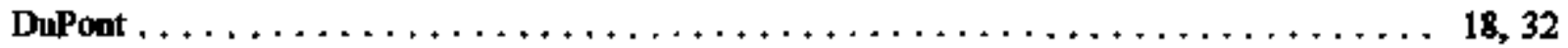

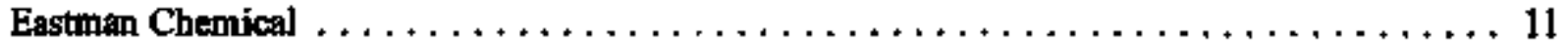

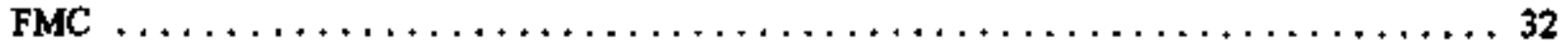

General Electric (GE) $\ldots \ldots \ldots \ldots \ldots \ldots \ldots \ldots \ldots \ldots \ldots \ldots \ldots \ldots \ldots \ldots \ldots \ldots \ldots$

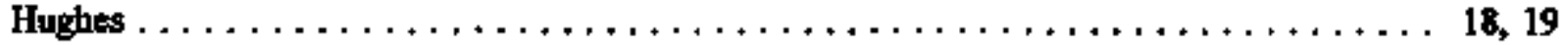

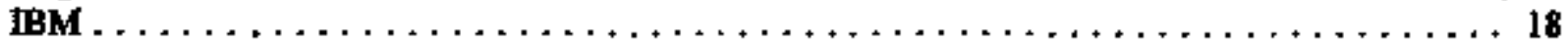

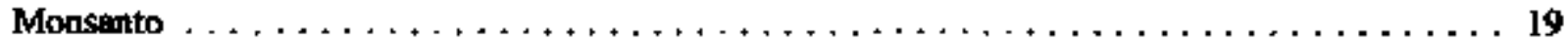

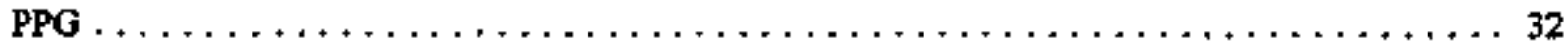

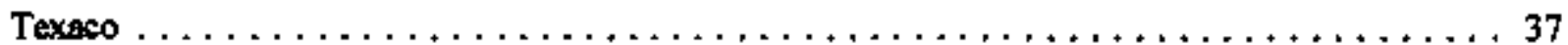

Computer $\ldots \ldots \ldots \ldots \ldots \ldots \ldots \ldots \ldots \ldots \ldots \ldots \ldots \ldots \ldots \ldots \ldots \ldots \ldots \ldots$ 18, 26, 39, 48, 74

Congress $\ldots \ldots \ldots \ldots \ldots \ldots \ldots \ldots \ldots \ldots \ldots \ldots \ldots \ldots \ldots \ldots \ldots \ldots, 19,25,54,71,72,97$

conservation $\ldots \ldots \ldots \ldots \ldots \ldots \ldots \ldots \ldots \ldots \ldots \ldots \ldots \ldots \ldots \ldots, 3,4,28,31,42,65,69,88,102$

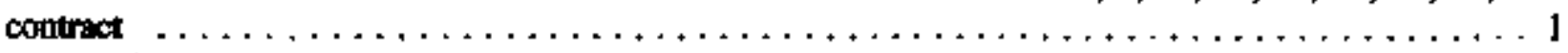

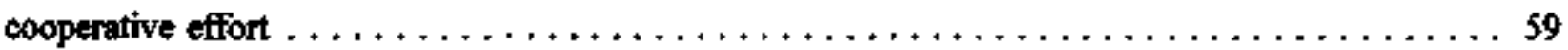

Cooperative State Research Service $\ldots \ldots \ldots \ldots \ldots \ldots \ldots \ldots \ldots \ldots \ldots \ldots \ldots \ldots \ldots$ v, $99,101,103$

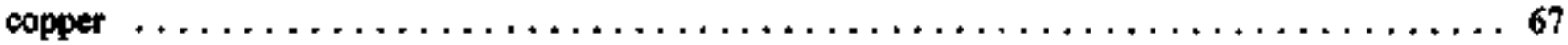

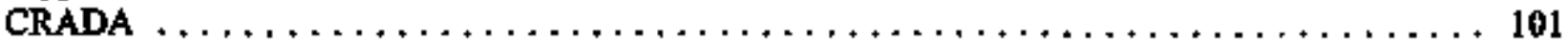

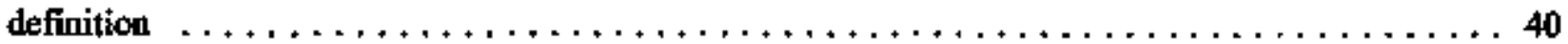

Department of Agriculture $\ldots \ldots \ldots \ldots \ldots \ldots \ldots \ldots \ldots \ldots \ldots \ldots \ldots, 2-6,8,35,75,99,101,103$

Department of Commerce (DoC) $\ldots \ldots \ldots \ldots \ldots \ldots \ldots \ldots \ldots v, 2,9-11,13,15,99,101,103,104$

Department of Defense (DoD) $\ldots \ldots \ldots \ldots \ldots \ldots \ldots \ldots \ldots \ldots \ldots \ldots$ v, 2, 17-26, 28, 98, 99, 101

Department of Energy (DoE) . . I, iji, v, vi, 1, 2, 20, 28, 29, 31-35, 37-40, 42-46, 48-52, 98, 99, 101 ,

103,105

Department of Health and Human Services $\ldots \ldots \ldots \ldots \ldots \ldots \ldots$ vi, 2, 53-55, 57-61, 63, 99, 103

Department of the interior $\ldots \ldots \ldots \ldots \ldots \ldots \ldots \ldots \ldots \ldots \ldots \ldots \ldots$ vi, $2,65-68,100,101$

Department of Transportation $\ldots \ldots \ldots \ldots \ldots \ldots \ldots \ldots \ldots \ldots \ldots \ldots \ldots \ldots$ vi, 2, 69, 70, 100, 101

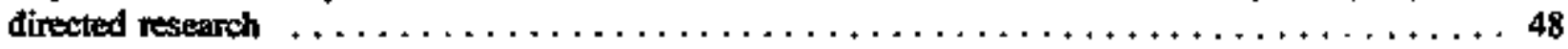

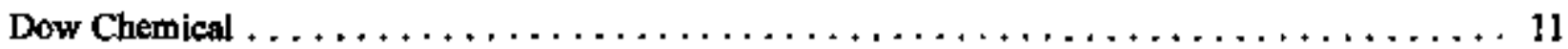

Dupont $\ldots \ldots \ldots \ldots \ldots \ldots \ldots \ldots \ldots \ldots \ldots \ldots \ldots \ldots \ldots \ldots \ldots \ldots \ldots \ldots \ldots \ldots \ldots \ldots \ldots \ldots, 32$

Eastman Chemical $\ldots \ldots \ldots \ldots \ldots \ldots \ldots \ldots \ldots \ldots \ldots \ldots \ldots \ldots \ldots \ldots \ldots \ldots \ldots \ldots$

economic $\ldots \ldots \ldots \ldots \ldots \ldots \ldots \ldots \ldots \ldots \ldots \ldots \ldots \ldots \ldots \ldots \ldots \ldots$ tii, 6,9, 10, 39, 76,81, 97

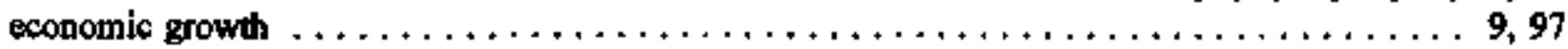

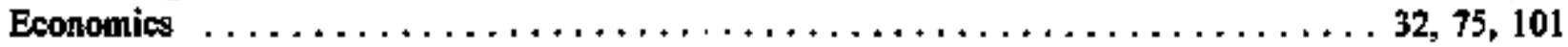

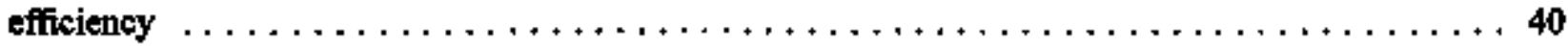

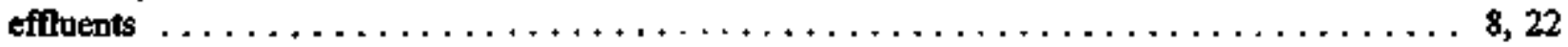

Electric Power Research Institute (EPRD) $\ldots \ldots \ldots \ldots \ldots \ldots \ldots \ldots \ldots \ldots \ldots \ldots \ldots \ldots$

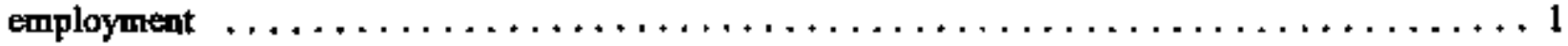

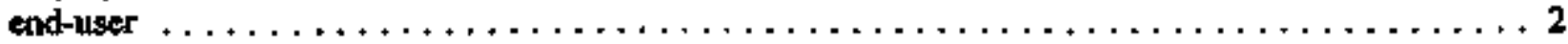

energy $\ldots \ldots 1$, iii, v, vi, $1,2,8,10,18,19,28,29,31-46,48-52,69,75,80,94,99,101,103,105$

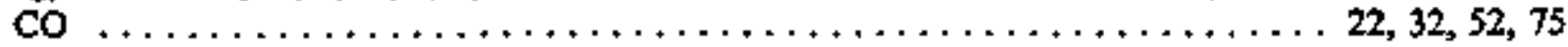

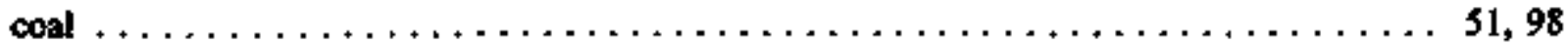

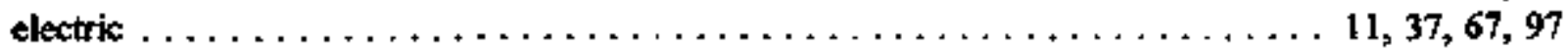

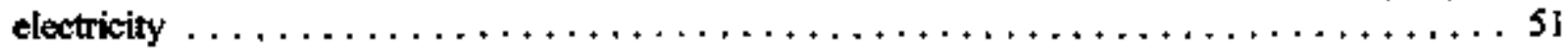

ethanol $\ldots \ldots \ldots \ldots \ldots \ldots \ldots \ldots \ldots \ldots \ldots \ldots \ldots \ldots \ldots \ldots \ldots \ldots \ldots \ldots \ldots \ldots, 35$ 
Fossil vi, $1,32,46,51,99$

hydrogen $37,38,45$

nagtural gas $47,51,69$

oil

petroleum $6,7,11,19,33,35,37,44,51,52$

waste heat 1,32 wood

8,80 energy conservation $28,31,69$ energy consumption energy research environment $v, 40,42,44-46,48,51,52,99,103$

\section{RCRA}

SUPERFUND environmentak

Environmental Protection Agency (EPA) iii, v, vi, vii, $1,2,4,11,18,19,26,28,29,32,42,44,46,48-50,54,55,58-60$ $65-68,70-76,78,79,81,88-91,93,98-103$ ethanol $v i, 2,28,32,34,60,71-81,98,100,101,103$

Federal Government 5-7, 35

feedstock iii, $15,19,31,37,46,61,79$

fertilizer $2,35,36$

FMC 37,97

food v, vi, 3, 5, 6, 57-59, 100,101 Forest Service $v, 8,99$ fossil mergy vi, $46,51,99$ fuel GASES

ammonia

Benzene $55,74,81$

CFC 34

Chlorofluorocarbons $22,32,52,75$ co

$\mathrm{CO}_{2}$ 80,101

hydrogen $37,38,45$

Methane 45,51

Methenol $18,32,35$

coone $28,78,98$

Toluene

VOC

19,102

Volatile Organic Compound

19,102

Xylene

General Electric (GE)

glass.

Global warming

goal GOVERNMENT ORGANIZATIONS

Air Force $32,35,50,60,92$ $v, 17,19,21,22,99,103$ 
Army $v, 17,19,23,24,99$

Bureau of Mines vi, $66-68,100$

Bureau of the Census $\mathrm{v}, 10,99$

Centers for Disease Control and Prevention (CDC)

$54,56,99-101$

Defense Programs

Department of Agriculture

$\ldots \ldots .7,39$

Department of Commere (DoC) $\ldots \ldots \ldots \ldots \ldots \ldots \ldots \ldots \ldots$ v, 2, 9-11, 13, 15, 99, 101, 103, 104
Depertment of Defense (DoD) $\ldots \ldots \ldots \ldots \ldots \ldots \ldots \ldots \ldots \ldots \ldots \ldots, 2,17.26,28,98,99,101$

v, 2-6, 8, 35, 75, 99, 101, 109

Department of Energy (DoE) . . . t, iii, v, vi, 1, 2, 20, 28, 29, 31-35, 37-40, 42-46, 48-52, 98, 99 ,

$101,103,105$

Department of Health and Human Services

vi, $2,53-55,57-61,63,99,103$

Departinent of Transportation

Environmental Protection Agency (EPA)

vi, 2, 69, 70, 100, 101

Food and Drug Administration (FDA)

$v i, 2,28,32,54,60,71-81,98,100,101,103$

Forest Service vi, 57.59, 100, 10]

.

National Aeronautics and Space Administration (NASA) . . . . iii, vii, 2, 19, 83-85, 100, 101, 104

National Institute for Standards and Techmology (NIST) $\ldots \ldots \ldots \ldots \ldots \ldots .11-15,99,101,104$

National Institutes of Health (NIH)

vi, 59-61, 100,101

National Science Foundation (NSF) . . . . . . . . vii, 2, 19, 74, 87, 88, 90-94, 100, 101

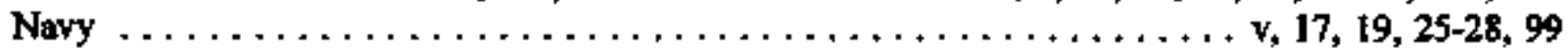

Office of Energy Efficiency and Renewable Energy $\ldots \ldots \ldots \ldots \ldots \ldots, v, 1,32,34,35,37,99$

Small Business Innovation Research (SBIR) .. v, vi, 19, 20, 22, 23, 26, 27, 46, 47, 63, 81, 92, 99 ,

Tennessee Valley Authority (TVA)

102,103

grant

guayule.

vii, $2,97,98,102$

hazandous waste $\ldots \ldots \ldots \ldots \ldots \ldots \ldots \ldots \ldots \ldots \ldots \ldots \ldots \ldots \ldots \ldots \ldots \ldots, 67$

Hazardous Wastes $\ldots \ldots \ldots \ldots \ldots \ldots \ldots \ldots \ldots \ldots \ldots \ldots \ldots \ldots \ldots \ldots \ldots \ldots \ldots$

high-risk $\ldots \ldots \ldots \ldots \ldots \ldots \ldots \ldots \ldots \ldots \ldots \ldots \ldots \ldots \ldots \ldots \ldots \ldots \ldots \ldots \ldots \ldots \ldots \ldots, 46,46$

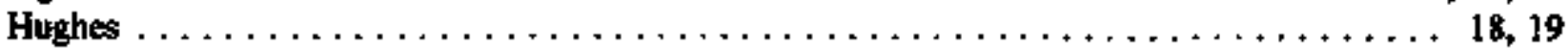

Hyatrogen Energy Coordinating Committe $\ldots \ldots \ldots \ldots \ldots \ldots \ldots \ldots \ldots \ldots \ldots \ldots \ldots \ldots$

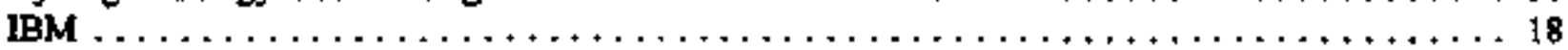

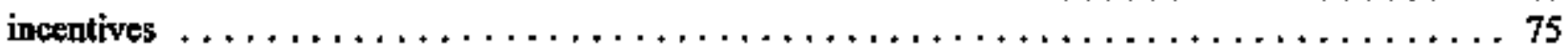

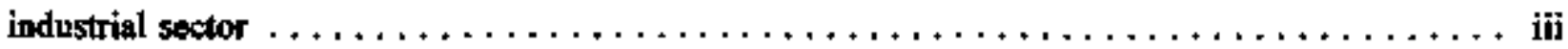

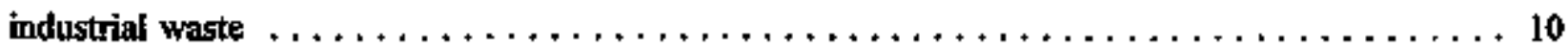

imnovation $\ldots \ldots \ldots \ldots \ldots \ldots \ldots \ldots$ v, vi, vii, $19,22,23,26,46,57,63,81,92,99,100,102,103$

instrumentation $\ldots \ldots \ldots \ldots \ldots \ldots \ldots \ldots \ldots \ldots \ldots \ldots \ldots \ldots \ldots \ldots \ldots \ldots, 48,61,81,91,93$

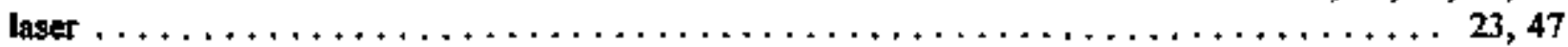

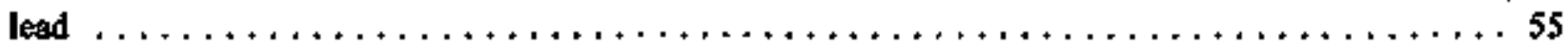

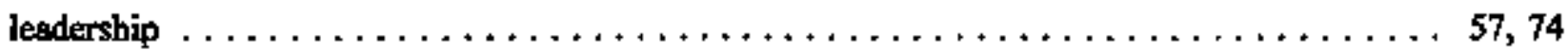

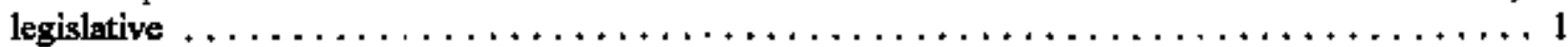

LIQUIDS

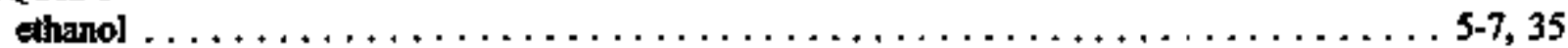

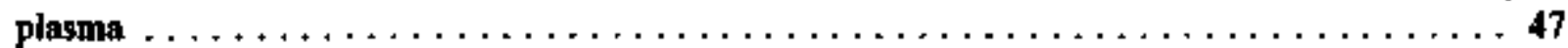

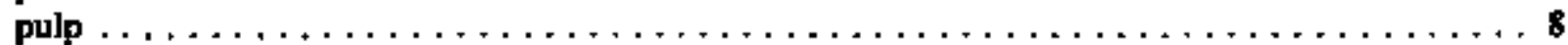

water $\ldots \ldots \ldots \ldots \ldots \ldots \ldots \ldots \ldots \ldots \ldots \ldots \ldots \ldots \ldots \ldots, 27,28,32,34,37,65,71,76,88$ 
long-term

METC

minimization

Mining

Monsanto

Morgantown Energy Techinology Center

plasma 


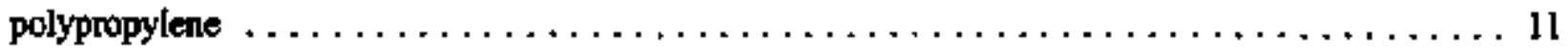

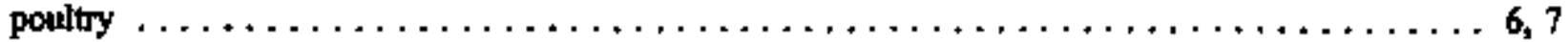

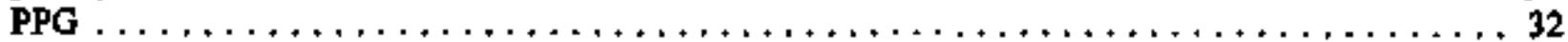

president $\ldots \ldots \ldots \ldots \ldots \ldots \ldots \ldots \ldots \ldots \ldots \ldots \ldots \ldots \ldots \ldots \ldots \ldots \ldots \ldots, 17,72$

private sector $\ldots \ldots \ldots \ldots \ldots \ldots \ldots \ldots \ldots \ldots \ldots \ldots \ldots \ldots \ldots \ldots$ iit, 13, 28, 48, 54, 98

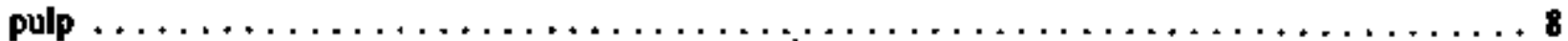

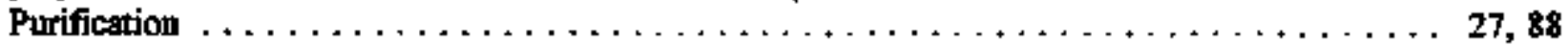

Radiation $\ldots \ldots \ldots \ldots \ldots \ldots \ldots \ldots \ldots \ldots \ldots \ldots \ldots \ldots \ldots \ldots \ldots \ldots \ldots 15,42,48,71$

reaction $\ldots \ldots \ldots \ldots \ldots \ldots \ldots \ldots \ldots \ldots \ldots \ldots \ldots \ldots \ldots \ldots \ldots \ldots \ldots \ldots, \ldots \ldots, 96,94$

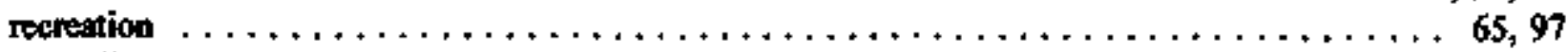

Recycting $\ldots \ldots \ldots \ldots \ldots \ldots \ldots \ldots \ldots \ldots \ldots \ldots \ldots \ldots \ldots \ldots \ldots \ldots \ldots \ldots \ldots \ldots, 6,32,67,70,98$

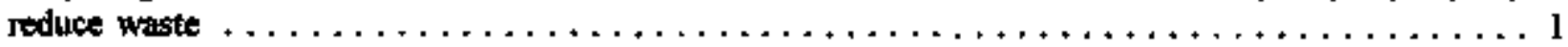

refigerants $\ldots \ldots \ldots \ldots \ldots \ldots \ldots \ldots \ldots \ldots \ldots \ldots \ldots \ldots \ldots \ldots \ldots \ldots, 15,28,34,72$

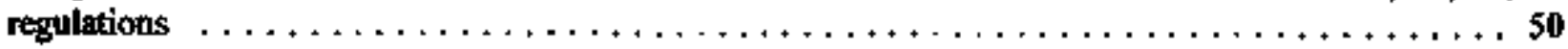

regulatory $\ldots \ldots \ldots \ldots \ldots \ldots \ldots \ldots \ldots \ldots \ldots \ldots \ldots \ldots \ldots \ldots \ldots, 6,11,31,58,59,74$

remediation $\ldots \ldots \ldots \ldots \ldots \ldots \ldots \ldots \ldots \ldots \ldots \ldots \ldots \ldots \ldots \ldots \ldots, 22,28,46,50,98$

renewable $\ldots \ldots \ldots \ldots \ldots \ldots \ldots \ldots \ldots \ldots \ldots l$, iii, v, 1, 8, 11, 28, 32, 34, 35, 37, 40, 52, 99

risk $\ldots \ldots \ldots \ldots \ldots \ldots \ldots \ldots \ldots \ldots \ldots$ vi, $31,40,46,50,55,58,74,78,79,100,101$

Sindia National Laboratories (SNL) $\ldots \ldots \ldots \ldots \ldots \ldots \ldots \ldots \ldots \ldots \ldots \ldots \ldots, 37,52$

Sensing $\ldots \ldots \ldots \ldots \ldots \ldots \ldots \ldots \ldots \ldots \ldots \ldots \ldots \ldots \ldots \ldots \ldots \ldots \ldots \ldots, 47$

Separation $\ldots \ldots \ldots \ldots \ldots \ldots \ldots \ldots \ldots \ldots \ldots \ldots \ldots \ldots \ldots \ldots \ldots \ldots \ldots, 47,61,88$

$\operatorname{sic} \ldots \ldots \ldots \ldots \ldots \ldots \ldots \ldots \ldots \ldots \ldots \ldots \ldots \ldots \ldots \ldots \ldots \ldots, 32,102$

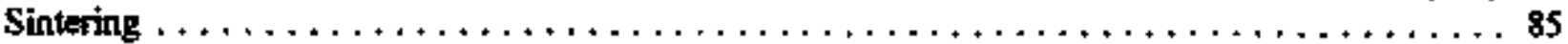

small business $\ldots \ldots \ldots \ldots \ldots \ldots \ldots \ldots \ldots$ v, vi, 19, 22, 23, 26, 46, 63, 72, 81, 92, 99, 102, 103

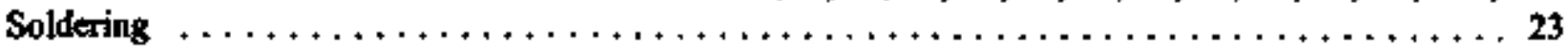

solicitation $\ldots \ldots \ldots \ldots \ldots \ldots \ldots \ldots \ldots \ldots \ldots \ldots \ldots \ldots$ vi, 11, 12, 19, 20, 22, 63, 72, 76

SOLIDS

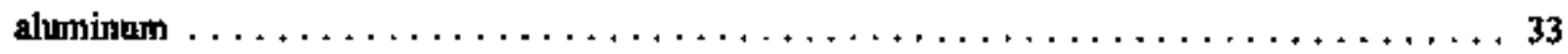

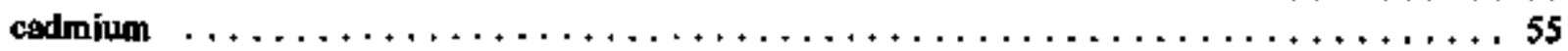

ceramics $\ldots \ldots \ldots \ldots \ldots \ldots \ldots \ldots \ldots \ldots \ldots \ldots \ldots \ldots \ldots \ldots 11,15,39,66,93$

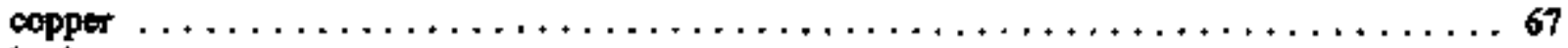

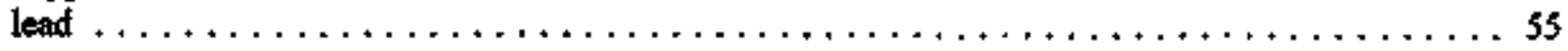

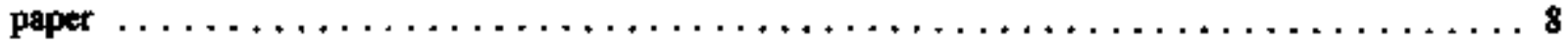

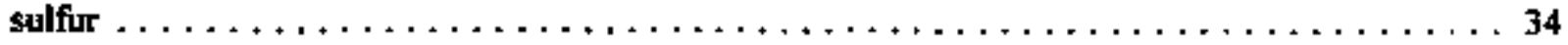

wood $\ldots \ldots \ldots \ldots \ldots \ldots \ldots \ldots \ldots \ldots \ldots \ldots \ldots \ldots \ldots, \mathbf{8 , 8}, \mathbf{8 0}$

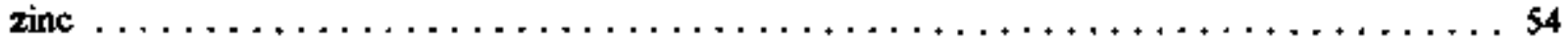

solventless $\ldots \ldots \ldots \ldots \ldots \ldots \ldots \ldots \ldots \ldots \ldots \ldots \ldots \ldots \ldots \ldots \ldots \ldots \ldots, 70,76$

source reduction $\ldots \ldots \ldots \ldots \ldots \ldots \ldots \ldots \ldots \ldots \ldots \ldots \ldots \ldots \ldots \ldots \ldots \ldots, 7,79$

styrene $\ldots \ldots \ldots \ldots \ldots \ldots \ldots \ldots \ldots \ldots \ldots \ldots \ldots \ldots \ldots \ldots \ldots \ldots \ldots \ldots,{ }^{74}$

substrates $\ldots \ldots \ldots \ldots \ldots \ldots \ldots \ldots \ldots \ldots \ldots \ldots \ldots \ldots \ldots \ldots \ldots \ldots \ldots \ldots \ldots \ldots \ldots \ldots \ldots \ldots \ldots, 63,94$

sulfur $\ldots \ldots \ldots \ldots \ldots \ldots \ldots \ldots \ldots \ldots \ldots \ldots \ldots \ldots \ldots \ldots \ldots \ldots \ldots \ldots \ldots, 14$

sulfuric acid $\ldots \ldots \ldots \ldots \ldots \ldots \ldots \ldots \ldots \ldots \ldots \ldots \ldots \ldots \ldots \ldots \ldots \ldots \ldots \ldots \ldots, 1,76$

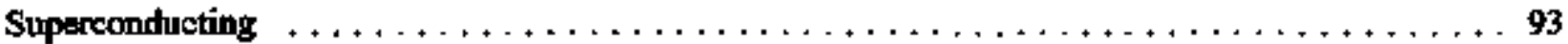

Supercritical $\ldots \ldots \ldots \ldots \ldots \ldots \ldots \ldots \ldots \ldots \ldots \ldots \ldots \ldots \ldots \ldots \ldots, \mathbf{7 , 2 8 , 8 0}$

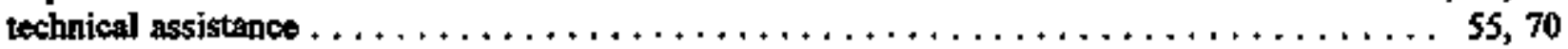

TECHNOLOGTES 
biocatalysis $\ldots \ldots \ldots \ldots \ldots \ldots \ldots \ldots \ldots \ldots \ldots \ldots \ldots \ldots \ldots \ldots \ldots \ldots \ldots \ldots, 12$

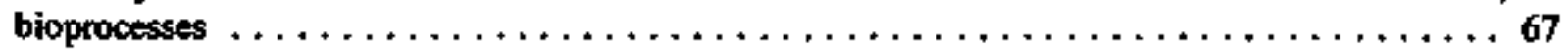

biotechnology $\ldots \ldots \ldots \ldots \ldots \ldots \ldots \ldots \ldots \ldots \ldots 13,14,35,36,48,62,84,85,88,89,98$

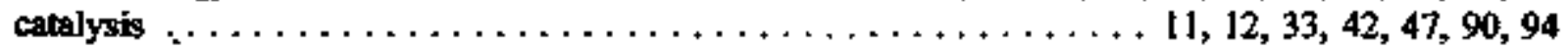

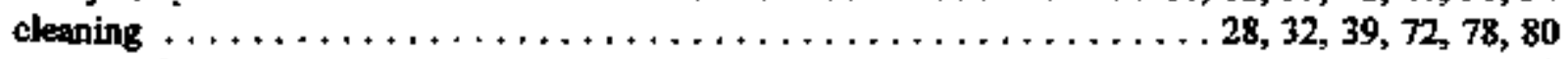

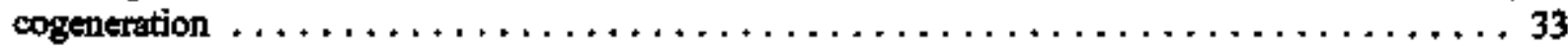

computer $\ldots \ldots \ldots \ldots \ldots \ldots \ldots \ldots \ldots \ldots \ldots \ldots \ldots \ldots \ldots \ldots \ldots \ldots$ 18, 26, 39, 48, 74

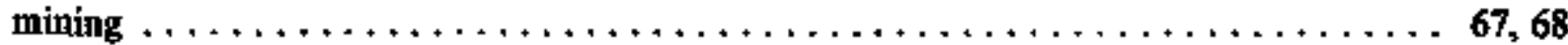

plotosynthesis $\ldots \ldots \ldots \ldots \ldots \ldots \ldots \ldots \ldots \ldots \ldots \ldots \ldots \ldots \ldots \ldots \ldots \ldots \ldots \ldots \ldots$ 44,94

purification $\ldots \ldots \ldots \ldots \ldots \ldots \ldots \ldots \ldots \ldots \ldots \ldots \ldots \ldots \ldots \ldots \ldots \ldots \ldots \ldots \ldots \ldots, 27,88$

radiation $\ldots \ldots \ldots \ldots \ldots \ldots \ldots \ldots \ldots \ldots \ldots \ldots \ldots \ldots \ldots \ldots \ldots \ldots \ldots \ldots \ldots \ldots \ldots, 42,48,71$

recycting $\ldots \ldots \ldots \ldots \ldots \ldots \ldots \ldots \ldots \ldots \ldots \ldots \ldots \ldots \ldots \ldots \ldots+1,6-8,32,67,70,98$

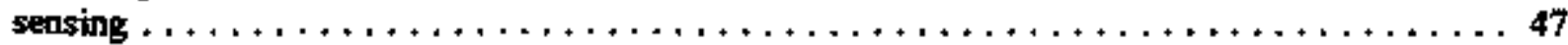

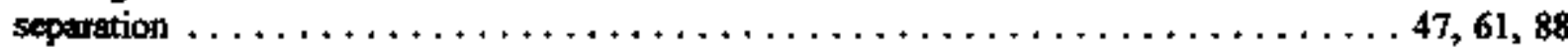

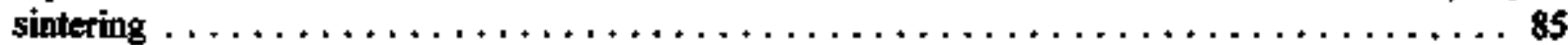

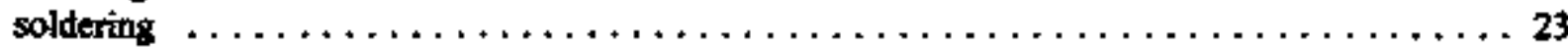

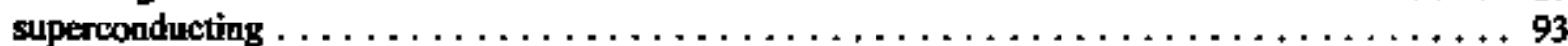

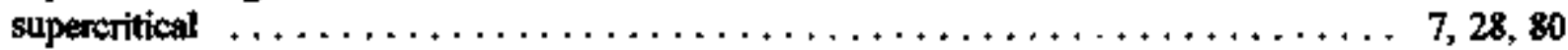

treatment $\ldots \ldots \ldots \ldots \ldots \ldots \ldots \ldots \ldots \ldots \ldots \ldots \ldots \ldots \ldots \ldots \ldots \ldots \ldots \ldots \ldots, 27,28,40,63,68,76$

ultrasenic $\ldots \ldots \ldots \ldots \ldots \ldots \ldots \ldots \ldots \ldots \ldots \ldots \ldots \ldots \ldots \ldots \ldots \ldots, 32$

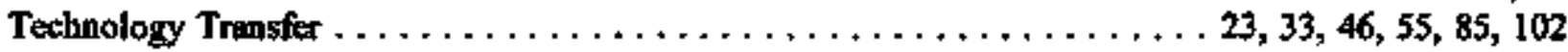

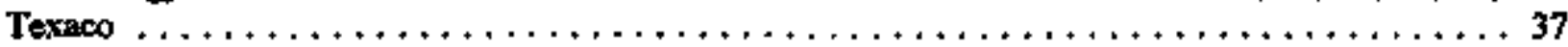

toxicity $\ldots \ldots \ldots \ldots \ldots \ldots \ldots \ldots \ldots \ldots \ldots \ldots \ldots \ldots \ldots \ldots \ldots \ldots \ldots \ldots \ldots \ldots \ldots \ldots, 54,58,60,63$

transportation $\ldots \ldots \ldots \ldots \ldots \ldots \ldots \ldots \ldots \ldots \ldots \ldots$ v, vi, 2, 19, 35-37, 69, 70, 72, 99-101

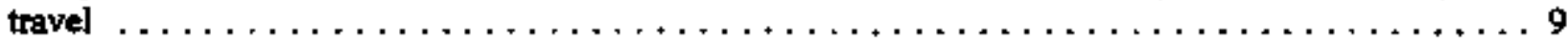

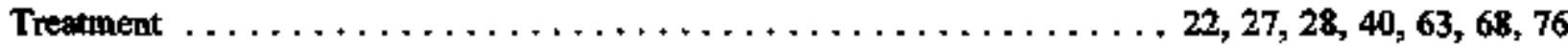

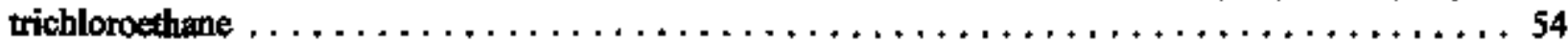

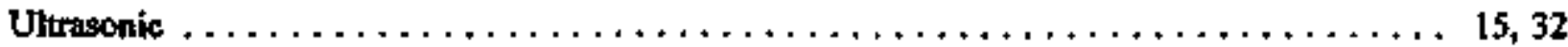

VOC $\ldots \ldots \ldots \ldots \ldots \ldots \ldots \ldots \ldots \ldots \ldots \ldots \ldots \ldots \ldots \ldots \ldots \ldots \ldots \ldots \ldots \ldots \ldots \ldots, 8,28,102$

Volatile Organic Compourd $\ldots \ldots \ldots \ldots \ldots \ldots \ldots \ldots \ldots \ldots \ldots \ldots \ldots \ldots \ldots \ldots$. $\ldots \ldots \ldots$. $\ldots \ldots 2$

water $\ldots \ldots \ldots \ldots \ldots \ldots \ldots \ldots \ldots \ldots \ldots \ldots \ldots, 4,27,28,32,34,37,65,71,76,88$

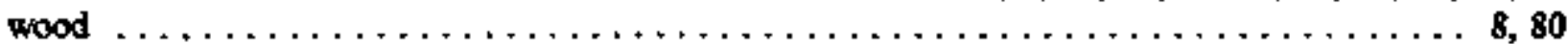

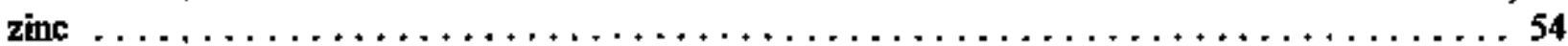

